\title{
The Royal Prerogative and Constitutional Law
}

This book examines the royal prerogative in terms of its theory, history, and application today.

The work explores the development of the royal prerogative through the evolution of imperial government, and more recent structural changes in the United Kingdom and elsewhere in the Commonwealth. While examining specific prerogative powers, the development of justiciability of the prerogative, and the exercise of the prerogative, it lays bare the heart of constitutionality in the Westminster system of government. There is said to be a black hole of unaccountable authority at the heart of the constitution and it is this which this book examines. The focus is upon the constitutional development of the United Kingdom and the old dominions of Canada, Australia, and New Zealand. This approach is comparative and historical, using specific case studies of such events as the dissolution of Parliament and the appointment and dismissal of Prime Ministers.

The book will be of interest to academics and researchers working in the areas of constitutional law and politics.

Noel Cox is a Barrister and Solicitor of the High Court of New Zealand. Formerly Professor of Law at Aberystwyth University and at the Auckland University of Technology. 


\section{Routledge Research in Legal History}

The Royal Prerogative and Constitutional Law

A Search for the Quintessence of Executive Power

Noel Cox

Procedural Justice and Relational Theory

Empirical, Philosophical, and Legal Perspectives

Edited by Denise Meyerson, Catriona Mackenzie, and Therese MacDermott

See more at https://www.routledge.com/Routledge-Research-in-Legal-History/ book-series/RRLEGHIST. 


\section{The Royal Prerogative and Constitutional Law}

A Search for the Quintessence of

Executive Power

Noel Cox 
First published 2021

by Routledge

2 Park Square, Milton Park, Abingdon, Oxon OX14 4RN

and by Routledge

52 Vanderbilt Avenue, New York, NY 10017

Routledge is an imprint of the Taylor \& Francis Group, an informa business

(C) 2021 Noel Cox

The right of Noel Cox to be identified as author of this work has been asserted by them in accordance with sections 77 and 78 of the Copyright, Designs and Patents Act 1988.

All rights reserved. No part of this book may be reprinted or reproduced or utilised in any form or by any electronic, mechanical, or other means, now known or hereafter invented, including photocopying and recording, or in any information storage or retrieval system, without permission in writing from the publishers.

Trademark notice: Product or corporate names may be trademarks or registered trademarks, and are used only for identification and explanation without intent to infringe.

\section{British Library Cataloguing in Publication Data}

A catalogue record for this book is available from the British Library

\section{Library of Congress Cataloging-in-Publication Data}

Names: Cox, Noel, 1965- author.

Title: The royal prerogative and Constitutional Law : a search for the quintessence of executive power / Noel Cox.

Description: Abingdon, Oxon ; New York, NY : Routledge, 2020. | Series: Routledge research in legal history | Includes bibliographical references and index.

Identifiers: LCCN 2020014133 (print) | LCCN 2020014134 (ebook) | ISBN 9780367500795 (hardback) | ISBN 9781003048718 (ebook)

Subjects: LCSH: Prerogative, Royal-Great Britain. | Prerogative, Royal-Commonwealth countries.

Classification: LCC KD4435 .C69 2020 (print) | LCC KD4435 (ebook) | DDC 342/.1241062-dc23

LC record available at https://lccn.loc.gov/2020014133

LC ebook record available at https://lccn.loc.gov/2020014134

ISBN: 978-0-367-50079-5 (hbk)

ISBN: 978-1-003-04871-8 (ebk)

Typeset in Galliard

by Taylor \& Francis Books 
To my dearly beloved wife Katy, whose support, patience and understanding are always appreciated, and to my late twin brother John, with whom many of the issues covered in this work were discussed, and to whom they were ever important. 
$\Longrightarrow$ Taylor \& Francis Taylor \& Francis Group http://taylorandfrancis.com 


\section{Contents}

Preface $\quad$ ix

Introduction 1

1 The origins of the prerogative 20

1.1 Introduction 20

1.2 The origins of the prerogative 21

1.3 Competing conceptions of the origins of authority 22

1.4 The seventeenth century 34

1.5 Conclusion 38

2 The nature of the prerogative

2.1 Introduction 39

2.2 The nature of the prerogative 40

2.3 Alternative ways of categorising the royal prevogative 46

2.4 Acts of State 52

2.5 Conclusion 54

3 The scope of the prerogative

3.1 Introduction 55

3.2 The scope of the royal prevogative 56

3.3 The appointment and dismissal of a Prime Minister 78

3.4 Conclusion 81

4 Classification of the prerogative

4.1 Introduction 83

4.2 Classification of the prevogative 88

4.3 Conclusion 102 
viii Contents

5 The extension of the prerogative to the colonies

5.1 Introduction 103

5.2 The extension of the prerogative to the colonies 105

5.3 Black's case 123

5.4 Conclusion 133

6 Judicial review of the prerogative

6.1 Introduction 134

6.2 Legal control of the prerogative 138

6.3 Judicial review of the prerogative 139

6.4 R. (Miller) v. The Prime Minister; Cherry \& Ors. v. Advocate

General for Scotland 152

6.5 Conclusion 164

7 The prerogative and statute

166

7.1 Introduction 166

7.2 The prevogative and statute 167

7.3 Conclusion 178

8 The prerogative and convention

8.1 Introduction 179

8.2 The prevogative and convention 184

8.3 Coronation oaths and the prevogative 194

8.4 Political accountability 198

8.5 Conclusion 201

9 Curtailment of the prerogative

9.1 Introduction 202

9.2 Curtailment of the prevogative 203

9.3 Limitations on the prerogative 209

9.4 The fate of the prerogative in Ireland 210

9.5 Conclusion 214

Conclusion

Note on the author

Bibliography

Index 


\section{Preface}

The British constitution is marked by the unusual characteristics of being unwritten and uncodified. Thus, although it embraces such concepts as the rule of law and the separation of powers, all is not certain, settled or predictable. It is certainly not immutable or unchanging. As an example, the well-known doctrine of the separation of powers has been but imperfectly applied, despite Montesquieu's description of it as being central to the British constitution in the eighteenth century, and judicial support for the view that the constitution is firmly based on the doctrine. Indeed, the departure from the simplistic purity of the doctrine seems to have been pivotal to the success of the Westminster system of parliamentary democracy. This dichotomy is at the heart of the British constitution, and arguably helps give it its flexibility and longevity. Another of the distinctive features of the common law constitution in the British tradition is the nature and characteristics of the executive power, the historic core of which is the royal prerogative. In addition, conventions provide a significant gloss on the notional or nominal powers of the executive (as well as the substantive), which are at least formally extensive, and govern the conduct of the legislature and judiciary, and their relationship with each of the other parts of government. Excepting, in most instances, its unwritten and unentrenched nature, this constitutional model was exported to the countries of the Commonwealth, and many others which have been influenced by British constitutional thought and practice and by the common law legal system.

The constitution is distinguished, amongst other things, by the existence of the royal prerogative. This may be described as the residual powers, privileges and immunities which the Crown, as personification of the State (or the Sovereign as head of State, depending upon the specific prerogative, and the circumstances), retains which are not dependent upon the legislative authority of the Sovereignin-Parliament. The prerogative has a number of elements which continue to be of use regularly today by the executive branch of government. One is the honours prerogative. This has been used to control the use of armorial bearings, and to regulate matters which, in England and Scotland, are the concern of specialist courts, as well as to bestow honours and decorations. More politically sensitive prerogatives include the war powers, and the control of the civil and military services - though both the latter are now in part at least regulated by statute. Perhaps 


\section{x Preface}

most important today, constitutionally speaking, are the political prerogatives of the appointment and dismissal of Prime Ministers, and the summoning, prorogation and (until the passage of the Fixed-term Parliaments Act 2011 (U.K.)) the dissolution of Parliament. All of these prerogatives have, at some time in the past, been the subject of controversy, and in some cases remain so. At the very least they have been the focus of attention when the royal prerogative, or rather its curtailment, is discussed. Many, if not most, apply in almost all those countries which have been influenced by British constitutional theory, excepting some where it was abolished, expressly or by implication, and always subject to any statutory abrogation or reform.

The royal prerogative remains a unique and separate area of law, founded in custom and the necessary attributes of kingship, or executive government as we would more usually say today. In such an environment, of a gradually waning prerogative, it might be questioned why one would embark upon a major new study of the prerogative, particularly since it might be thought that prerogative powers were either very well understood, or were facing extinction. But the answer lies partly in the question. There hasn't been a full systematic analysis of the scope and nature of the royal prerogative for many years - perhaps not since Chitty in 1820. When we are considering codifying, or abolishing the prerogative, it would be logical to proceed from the basis of a thorough understanding of what we are reviewing. One must also distinguish between the factual existence of the prerogative and the normative role it plays, and between the concept of the Crown and the exercise of the prerogative. Recent events, such as the judicial review of the royal prerogative of prorogation, have again placed the prerogative in the spotlight, and raised questions about the role of the prerogative.

The scope of the royal prerogative power is notoriously difficult to determine. It is clear that the existence and extent of the power is a matter of common law, making the courts the final arbiter of whether or not a particular type of prerogative power exists. The difficulty is that there are many prerogative powers for which there is no recent judicial authority and sometimes no judicial authority at all. In such circumstances, the Government, Parliament and the wider public are left relying on statements of previous Government practice and legal textbooks, the most comprehensive of which is now 200 years old.

This uncertainty has been criticised. Professor Rodney Brazier has written, ${ }^{1}$

... the demand for a statement of what may be done by virtue of [the royal prerogative] is of practical importance. Yet it has been said judicially that such a statement cannot be arrived at, because only through a process of piecemeal judicial decisions over the centuries have particular powers been seen to exist, or not to exist, as the case may be.

1 Brazier, Robert, "Constitutional Reform and the Crown" in Sunkin, Maurice \& Sebastian Payne (eds.), The Nature of the Crown (1999), p. 339. 
It would seem that the royal prerogative is sufficiently flexible that it may be exercised in ways and circumstances different to those traditional to it - more on this when we consider Black's case. This is of increasing importance at a time when governments are finding it again necessary to have resort to executive authority to meet the exigencies of a resurgent terrorist threat.

Recent government papers, particularly The Governance of Britain - Review of the Executive Royal Prerogative Powers: Final Report (2009), have canvassed the situation, albeit relatively briefly. Key is the observation that:

The current Review has provided an opportunity for Government to examine the current state of the prerogative and, in this report, to provide for the first time a consolidated list of prerogative powers and to assess the case for further, wide-scale reform of those powers. The previous chapter summarised the difficulties .... to which any further narrowing of the prerogative could give rise .... [T] he Justice Secretary has said that he will explore alternative options for dealing with the exercise of the Royal prerogative in relation to applications for free pardons. Some of the remaining prerogative powers could be candidates for abolition or reform, but their continued existence has - at the minimum - no significant negative effects. In many cases it is positively useful. Legislation to replace some of them could itself give rise to new risks: of unnecessary incursions into civil liberties on the one hand, or of dangerously weakening the state's ability to respond to unforeseen circumstances on the other.

This leaves us with the difficulty that, as Brazier noted, the prerogative remains important but lacks a definitive definition. The identification of that is what is here proposed, though as has been observed by Poole,

The defining characteristic of the prerogative is that its exercise does not require the approval of Parliament. Beyond this bare account, there is little agreement either on the definition of the concept itself - those two giants of English public law scholarship, Blackstone and A. V. Dicey, gave contrasting accounts - or even as to the precise scope of the powers still extant. $^{2}$

The intention of this work is not to cover the well-trodden paths of judicial review of the prerogative (though the expansion of that procedure is explored). Instead, it will seek to review the origins, nature and classifications of the prerogative, in search of a hitherto common element - beyond the simple (or not so simple) definitions given above. It is unapologetically historical, for as Sir Walter Scott observes in Guy Mannering,

2 Poole, Thomas, "United Kingdom: The royal prerogative" (2010) 8(1) I•CON 146155, 146. 
xii Preface

A lawyer without history or literature is a mechanic, a mere working mason; if he possesses some knowledge of these, he may venture to call himself an architect. $^{3}$

Identifying a common element, or a coherence, to the prerogative may aid both in understanding the prerogative power and also assist in any endeavours to codify or replace it.

Whilst the abolition or codification of the prerogative might not inherently reduce the role of the Crown as the centrepiece of the constitutional framework, nonetheless, relocating authority, hitherto focussed on the executive branch of government, in the legislative or judicial, would constitute a rebalancing of the constitution, and should only be done with due care and attention not merely to detail but to the principles which have governed our polity for much of the past thousand years.

I would like to thank the various scholars, commentators, reviewers and myriad other people who are inevitably involved to some degree in the production of any work of this sort. As always, any errors and omissions remain mine alone.

Noel Cox

3 Scott, Sir Walter, Guy Mannering (1815). 


\section{Introduction}

This work is a study of the royal prerogative, that particular if not peculiar cluster of legal powers, privileges and immunities which were and to some extent still are, vested in the person and institution of the Sovereign of the United Kingdom and of the states which derive their constitutional form from that original. Whilst individual powers, privileges and immunities may, in particular countries, have been abolished, fallen into disuse, or been constrained by statutory intervention, the general form and nature of the royal prerogative remains in existence in the United Kingdom, and all those states which remain as Westminster-style constitutional monarchies, and in some countries in which, though now republics, the system was preserved. In general, this study focuses on the situation in the United Kingdom, but, although not strictly a comparative study, it is not limited to that country.

As Payne observed 'There is no single accepted definition of the royal prerogative. The various definitions appear to conflict with each other'. ${ }^{1}$ This presents difficulties for anyone attempting to understand the nature of the prerogative. ${ }^{2}$ The difficulty lies at the heart of the constitution, for, according to Blackstone (1765), the law of the constitution clothes the person of the Sovereign with supreme sovereignty and pre-eminence. ${ }^{3}$ Moreover, the rights, privileges, immunities and other legal attributes that make up the royal prerogative are derived

1 Payne, Sebastian, "The Royal Prerogative" in Maurice Sunkin \& Sebastian Payne (eds.), The Nature of the Crown: A Legal and Political Analysis (1999), p. 78.

2 In general, throughout this book the term 'prerogative' is preferred to 'royal prerogative'. This is not, unlike Markesinis, because of any belief that the expression 'royal' is a misnomer or anachronism, but simply for brevity. It must be noted, however, that it invites the criticism that there is a conceptual distinction between prerogative and royal prerogative. However, the reader's indulgence is begged, that allowance be made for this small liberty; c.f. Markesinis, Basil S., "The Royal Prerogative Revisited" (1973) 32 Cambridge L.J. 287.

3 Blackstone, Sir William, Commentaries on the Laws of England ed. E. Christian (14th edn., 1803), p. 241. This statement can be reconciled with the realities of the modern constitution only if it is understood that the Sovereign can lawfully and constitutionally act only in certain ways. Blackstone's enunciation of the Sovereign's sovereignty and pre-eminence is in fact the basis of the corollaries expressed, with qualifications. 


\section{Introduction}

from ancient custom and the common law. ${ }^{4}$ However, the Sovereign is bound by the terms of the coronation oath, and in what we might today blandly describe as constitutional conventions, to observe and obey the law. ${ }^{5}$

This is further complicated by the reality that the prerogative, though exercised by or in the name of the Sovereign, is (generally at least) exercised at the behest of ministers responsible to Parliament. In the Canadian case of Black $v$. Chrétien, ${ }^{6}$ the Court observed: 'As members of the Privy Council, the Prime Minister and other Ministers of the Crown may also exercise the Crown prerogative. ${ }^{7}$ This conclusion was based upon the judgment of Wilson J., in Operation Dismantle, that the prerogative power may be exercised by cabinet ministers and therefore does not lie exclusively with the Governor-General. ${ }^{8}$ This does not mean that a minister (or ministers collectively) can alone exercise a prerogative power, but rather the exercise of the prerogative is on the advice of these ministers - though when executed by means of an Order-in-Council, the ministers have an executive as well as advisory role. This terminology, however, illustrates the difficulty at time found in distinguishing between the factual existence of the prerogative and the normative role it plays, and between the practical exercise of the prerogative (generally) at the behest of Ministers of the Crown.

In a similar manner, in 2014 the House of Commons Political and Constitutional Reform Committee released a report on the Role and powers of the Prime Minister. The report broadly argued for more powers to be placed on a statutory footing, with parliamentary approval. The Report referred to a previous attempt by the Committee's Chair to promote placing the Prime Minister's powers under the prerogative on a statutory footing. In a private member's Bill, included in the report as an appendix, Graham Allen M.P. suggested a fixed, exhaustive list of prerogative powers exercisable by the Prime Minister:

1 To make Orders in Council.

2 To declare war or commit United Kingdom forces to armed conflict, but only after the House of Commons has given its approval.

3 To issue lawful command to the armed forces.

4 To require persons to perform military service or other service to the state in times of armed conflict or emergency.

5 To sign or ratify treaties.

6 To recognise foreign governments.

4 See Anson, Sir William, The Law and Custom of the Constitution ed. A.B. Keith (5th edn., 1922).

5 As to the common law, see Bracton, de, Henry, On the Laws and Customs of England (Henri de Bracton de Legibus et Constuetudinibus Anglia) ed. G.E. Woodbine; trans. S.E. Thorne (1968) (Bracton), lib. I, c. 8 (Bracton); Blackstone, Sir William, Commentaries on the Laws of England ed. E. Christian (14th edn., 1803), pp. 241-242.

6 Black v. Chrétien (2001) 199 D.L.R. (4th) 228 (Court of Appeal of Ontario).

7 Ibid, para. 32 per Laskin J.A.

8 Operation Dismantle Inc. v. The Queen [1985] I S.C.R. 411 (S.C. Canada). 
7 To appoint ambassadors, permanent secretaries of departments, the heads of the security services, members of the Defence Staff, Royal Commissions and members of public bodies.

8 To declare a state of emergency.

9 To order the confiscation, forfeiture or seizure of property and assets.

10 To issue pardons and detail felons or the insane during pleasure.

11 To institute or quash legal proceedings.

12 To assert Crown immunity in any legal proceedings and to grant public interest immunity certificates.

13 Powers in relation to intestacy, the failure of charitable trusts, treasure trove, mineral rights, wrecks, sturgeon, swans, whales, territorial waters and the ownership of the foreshore of the United Kingdom. ${ }^{9}$

Unfortunately, this contains a number of conceptual problems, from the misapplication of prerogatives actually in the hands of the law officers of the Crown, to the more fundamental mis-conception that these prerogatives are those of the Prime Minister; where some discretion remains in the hands of the Sovereign (however uncertain), these cannot be categorised as prerogatives controlled by the Prime Minister, much less his or her prerogatives. The report was not acted upon by Government.

The 1688 revolutionary settlement and the Bill of Rights (1688 or 1689) established beyond any doubt the supremacy of parliamentary statutes over the prerogatives of the monarch. The Sovereign's exercise of her executive prerogative powers in the modern constitution are regulated by conventions and the principles of ministerial responsibility, ${ }^{10}$ and now also by the growing justiciability of the prerogative.

Dicey (1885) gives what is generally regarded as the standard definition of what prerogative powers are:

The prerogative appears to be historically and as a matter of fact nothing else than the residue of discretionary or arbitrary authority which at any given time is legally left in the hands of the crown. The prerogative is the name of the remaining portion of the Crown's original authority ... Every act which the executive government can lawfully do without the authority of an Act of Parliament is done in virtue of the prerogative. ${ }^{11}$

The Diceyan view is the one most commentators follow, but some constitutional lawyers prefer the definition given a century earlier by William Blackstone:

By the word prerogative we usually understand that special pre-eminence which the King hath, over and above all other persons, and out of the

9 Political and Constitutional Reform Committee, Role and powers of the Prime Minister, First Report of Session 2014-15, H.C. 351, 24 June 2014, Appendix 2.

10 See Marshall, Geoffrey, Constitutional Conventions - The Rules and Forms of Political Accountability (1986).

11 Carroll, Alex, Constitutional and Administrative Law (4th edn, 2007), p. 246. 


\section{Introduction}

ordinary course of common law, in right of his regal dignity ... it can only be applied to those rights and capacities which the King enjoys alone, in contradiction to others, and not to those which he enjoys in common with any of his subjects. ${ }^{12}$

The two views are of course significantly divergent, if not inconsistent. Blackstone maintains that the prerogative simply covers those actions that no other person or body in the United Kingdom can undertake, such as the dissolution of Parliament. Powers which belong to subjects also cannot, ipso facto, be prerogative powers. Dicey would however regard these as prerogative powers, on the basis that 'every act which the executive government can lawfully do without the authority of an Act of Parliament is done in virtue of the prerogative'. ${ }^{13}$ This does not allow for the fact that some powers of the Crown are those which they share with the subject; and not all the prerogative is comprised of powers - it has always included immunities and privileges also. Yet, it is his definition which has garnered more judicial support. This will be considered at more length in Chapter 9.

The distinction between prerogative and statutory authority isn't the only way of approaching this issue. Wade $\operatorname{argued}^{14}$ - though Gordon wasn't persuaded by this - that Dicey was right when he, Dicey, used the distinction between legal sovereignty and political sovereignty. ${ }^{15}$ Parliament (strictly the Crown-in-Parliament) was the legal sovereign, and could not be bound; the prerogative was not vested in the Crown-in-Parliament, and therefore wasn't supreme law.

However, as Gordon argued, in the words of Loughlin,

$[\mathrm{t}]$ he basic question for constitutional lawyers is not whether we have a legal or political constitution: it is how the idea of law within the political constitution (i.e. the constitution of the polity) might best be conceptualized. ${ }^{16}$

Gordon prefers the definition offered by Jennings over that of Wade. ${ }^{17}$ Jennings argued that Parliament can bind its successors, as what Dicey called the supremacy of Parliament cannot be truly sovereign since it was limited by such as public opinion. ${ }^{18}$ Jennings argued that legal sovereignty is not sovereignty as the

12 Blackstone, Sir William, Commentaries on the Laws of England ed. E. Christian (4th edn., 1978), Vol. 3, article 2, section 1. Here and elsewhere the spelling (and occasionally punctuation) is modernised for any early quotation, though the text is otherwise unaltered.

13 Carroll, Alex, Constitutional and Administrative Law (4th edn, 2007), p. 246.

14 Wade, Sir William, "The Basis of Legal Sovereignty" (1955) Cambridge L.J. 172-197.

15 Dicey, Albert, Introduction to the Study of the Law of the Constitution (8th edn. 1915), pp. 70-74.

16 Loughlin, Martin, “Towards a Republican Revival?” (2006) 26(2) Oxford Journal of Legal Studies 425-437.

17 Gordon, Michael, "The Conceptual Foundations of Parliamentary Sovereignty: Reconsidering Jennings and Wade" (2009) Public Law 519-543.

18 Jennings, Sir Ivor The Law and the Constitution (5th edn., 1959), p. 147. 
legislative power of Parliament is derived from the common law. ${ }^{19}$ A true sovereign cannot be bound. However, although Parliament is not truly sovereign, it can alter the procedure by which law is enacted, in manner and form.

Whilst these arguments may appear semantic or overly technical, they do expose the diverse attitude to the fundamental core of the constitution - a lack of clarity that is inevitable in an evolutionary historic constitution that is not the product of a single directing formative mind.

Whichever definition of the prerogative is preferred (and even Dicey's is now over a century old, and showing signs of increasing age), we must first briefly canvas the history of the prerogative.

The royal prerogative may be defined as being that special pre-eminence which the Sovereign has over and above all other persons by virtue of the common law, ${ }^{20}$ but out of its ordinary course, in right of her regal dignity, ${ }^{21}$ and includes all the 'special dignities, liberties, privileges, powers and royalties allowed by the common law to the Crown of England'. ${ }^{22}$

19 Ibid, pp. 150, 156.

20 In theory, the Sovereign has supreme sovereignty and pre-eminence, and under the doctrine of perfection, can do no wrong: see Blackstone, Sir William, Commentaries on the Laws of England ed. E. Christian (14th edn., 1803), pp. 241-242, 245-246; Re M. [1994] 1 A.C. 377, sub nom M. v. Home Office [1993] 3 All E.R. 537 (H.L.).

21 Blackstone, Sir William, Commentaries on the Laws of England ed. E. Christian (14th edn., 1803), p. 239. Literally, the term 'prerogative' (praerogo) means something demanded before or in preference: ibid, p. 239. According to Sir Henry Finch 'by the prerogative that is law almost in every case of the King which is law in no case of the subject': Finch, Sir Henry, Discourse on the Law (reprinted 1759, first published 1627), lib. ii, p. 85. The prerogative was described by Dicey as 'both historically and as a matter of actual fact nothing else than the residue of discretionary or arbitrary authority which at any given time is legally left in the hands of the Crown' (Law of the Constitution (10th edn.), p. 424). This statement has been cited in a number of judgments, e.g. in Attorney-General v. De Keyser's Royal Hotel Ltd [1920] A.C. 508, 526 per Lord Dunedin (H.L.), but it is not strictly accurate, because the prerogative also includes rights and privileges of various kinds. The Lord Privy Seal, in a written answer in the House of Lords to the question 'what are the categories of powers exercised by ministers exclusively under the royal prerogative', said 'the government shares the view of Wade and Bradley, in their work on constitutional law, that it is not possible to give a comprehensive catalogue of prerogative powers': 568 H.L. Official Report (5th series), 1 February 1996, written answers, col 118; Wade, Sir Henry, Q.C. \& Bradley, A.W., Constitutional and Administrative Law (11th edn., 1993, first published 1931), p. 264.

22 Comyns, Sir John \& Hammond, A., A Digest of the Laws of England (5th edn., 1822) ('Com. Dig.'), Prerogative, A. Powers specially conferred upon the Crown cannot be said to form part of the prerogative, although the prerogative has frequently been defined and regulated by statute: see Convocations' Case (1611) 12 Co. Rep. 72; and the statute Prerogativa Regis (temp incert), the unrepealed portion of which declares the law on certain points as to wreck of the sea, royal fish (c 13) and the construction of royal grants (c 17) (see also (1891) 6 English Historical Review 367).

The use of the term 'the Crown' conveys the correct implication that prerogative powers are, with very few exceptions, exercised not by the Sovereign in person but in her name by her servants. Even where the Sovereign acts in person, she normally acts in accordance with the advice given to her by ministers. See Wade, Sir Henry, Q.C. \& 


\section{Introduction}

The prerogative is thus derived from ${ }^{23}$ and limited by the common law, and the Sovereign can claim no prerogatives except such as the law allows. ${ }^{24}$ In particular, no prerogative may be recognised that is contrary to Magna Carta or any other statute, ${ }^{25}$ or that interferes with the liberties of the subject. ${ }^{26}$

The extent of the prerogative being necessarily somewhat vague, it has been necessary at various times to define its limits more accurately by statute. ${ }^{27}$ The principal provisions, from a constitutional standpoint, were said to be found in four great statutes or charters by which the rights and liberties of the subject are preserved and 'acts of tyranny' by the Crown or its ministers restrained. The four great statutes or charters are Magna Carta of Edward I (1297) (Eng.); the Petition of Right (1627) (Eng.); the Bill of Rights 1689 (Eng.), confirmed by the Crown and Parliament Recognition Act 1689 (Eng.); and the Act of Settlement 1701 (Eng.). ${ }^{28}$ However, these statutes must not be regarded as curtailments of existing

Bradley, A.W., Constitutional and Administrative Law (11th edn., 1993, first published 1931), pp. 244-245, 261-264); and de Smith, S.A. \& Rodney Brazier, Constitutional and Administrative Law (7th edn, 1994), pp. 139-142.

23 Historically it is incorrect to say that the prerogative is 'created' by the common law, because it is the residue of royal authority left over from a time before it was effectually controlled by law; but, since the time of Bracton, who founded the royal authority on law, it has been legally correct to use that term.

24 Com Dig, Prerogative, A; Case of Proclamations (1611) 12 Co. Rep. 74, 75.

252 Co. Inst. 36, 54.

26 Blackstone, Sir William, Commentaries on the Laws of England ed. E. Christian (14th edn., 1803), p. 245. See also ex parte Barnsley (1744) 3 Atk. 168, 171; Case of Proclamations (1611) 12 Co. Rep. 74. The scope of the prerogative in home affairs has been so severely curtailed by statute that it is difficult to see how any act by or authorised by the Crown causing damage to a subject within the realm could be justified as having been lawfully done by virtue of the prerogative. But if that could possibly have occurred in time of peace, it seems that the subject would have a claim to compensation see Burmah Oil Co. (Burma Trading) Ltd v. Lord Advocate [1965] A.C. 75, [1964] All E.R. 348 (H.L.), not overruled on this point by the War Damage Act 1965 (U.K.).

27 The prerogative may also, in effect, be in abeyance where statute has enacted provisions which enable what might have been done under the prerogative to be done under the statute.

28 Magna Carta was first assented to by King John in 1215. It was confirmed, and sometimes extended but more frequently curtailed, more than 30 times between the reigns of Henry III and Henry IV. The confirmation and reissue of 1297, known as Magna Carta of Edward I (1297) is still in force as to cc. 1, 9, 29, 37, and to that extent still binds the Crown. The same applies to various of the confirming charters, namely the statute $25 \mathrm{Edw} .1$ (Confirmation of the Charters) (1297), cc. 1 (in part), 6; the statute 25 Edw. 3 stat. 5 (Executors) (1351-2), c. 5; the statute 28 Edw. 3 (1354), c. 3; the statute 7 Hen. 4 (Liberties, Charters and Statutes Confirmed) (1405-1406), c. 1; the statute 4 Hen. 5 stat. 2 (Confirmation of Charters and Statutes) (1415-16); and the statute 2 Hen. 6 (Confirmation of Liberties) (1423), c. 1. Constitutionally the most important of these charters is now Magna Carta of Edward I (1297) (25 Edw. 1).

The Petition of Right (1627) was drawn up by the Commons in 1627, and recited in particular Magna Carta of Edward I (1297) and the statute 25 Edw. I (Statute Concerning Tallage) (1297) (25 Edw. I), of which c. 1 is still in force. To the petition 
prerogatives, but as declarations of the fundamental laws of England (and now of the United Kingdom). ${ }^{29}$

The royal prerogative originated as the personal powers of the monarch. From the thirteenth century in England, as in France, the Sovereign was powerful, but what could have been almost absolute power was checked by Bracton's formulation that the King 'must not be under man but under God and under the law, because law makes the King', 30 and by 'the recrudescence of feudal turbulence in the fourteenth and fifteenth centuries'. During the sixteenth century, this turbulence began to recede, and the Sovereign became truly independent, building the modern state around the conception of the sovereign. The rise of Parliament in this period, however, was ultimately problematic for the position of the Sovereign. While the Sovereign was 'the predominant partner in the English constitution', the courts stopped short of declaring him allpowerful, recognising the role that Parliament played in the English constitution. ${ }^{31}$ In Ferrer's Case, ${ }^{32}$ this was recognised, the court expressly noting that the King was far more powerful with the consent of Parliament than without it. Nowhere was this more apparent than in the matter of taxation, over which a number of seminal decisions were made by the courts in the early years of the seventeenth century, in particular. Sir Thomas Smith and other writers of the period pointed out the Sovereign could not impose taxation without Parliament's consent. $^{33}$

At around the same time, King Henry VIII and his immediate descendants normally followed the views of the courts, despite the fact that they were theoretically not bound by judges in respect of the prerogative, provided the claimed prerogatives were accepted by the courts. Holdsworth inferred that by regularly asking the legal officers of the Crown and the judiciary for advice and consent, Henry VIII recognised the need for a stable government to follow the law. He also contended that the view that the law is supreme over all 'was the view of all the leading lawyers and statesmen and publicists of the Tudor period' ${ }^{34}$ It was accepted that while the King had 'unfettered discretion', he was limited in areas where the courts had imposed conditions on the use of the prerogative, or where

itself Charles I appended the answer 'Soit droit fait come est desire' (let right be done as is desired).

29 See Coke, Sir Edward, Coke upon Littleton (19th edn., 1979), Vol. II, proëm 3; Blackstone, Sir William, Commentaries on the Laws of England ed. E. Christian (14th edn., 1803), p. 128.

30 I.e. rex non debet esse sub homine, sed sub Deo et lege, quia lex facit regeni: Bracton, lib. I c. 8; 12 Co. Rep. 65; Fleta 2 c. 5; Chitty, Joseph, A Treatise on the Law of the Prerogatives of the Crown; And the Relative Duties and Rights of the Subject (1978), p. 5.

31 For instance, by extoling the pre-eminence of the law over all institutions, including the King.

32 Ferrer's Case (1598) 6 Co. Rep. 9a; 77 E.R. 266.

33 Smith, Sir Thomas, De Republica Anglorum; A Discourse on the Commonwealth of England ed. L. Alston (1970, first published 1583).

34 Holdsworth, Sir William, "The Prerogative in the Sixteenth Century" (1921) 21(6) Columbia L.R. 554-571, 556. 


\section{Introduction}

he himself had chosen to do so. ${ }^{35}$ The latter is particularly interesting, and resembles a form of self-adopted convention.

The first challenge to this stability - based on mutual restraint between Sovereign and courts - came about in 1607, with Probibitions del Roy. ${ }^{36}$ King James I claimed that, as Sovereign, he had a divine right to sit as a judge and interpret the common law as he saw fit. Led by Sir Edward Coke, the judiciary rejected this idea, stating that while the Sovereign was not subject to any individual, he was subject to the law. Until he had gained sufficient knowledge of the law, he had no right to interpret it; Coke pointed out that such knowledge 'demanded mastery of an artificial reason ... which requires long study and experience, before that a man can attain to the cognizance of it'. ${ }^{37}$ Whilst this may be a somewhat artificial argument (it opened up the prospect of a legally trained Sovereign asserting their authority over the common law), it nonetheless restrained royal interference in the sphere of responsibility of the judiciary. Similarly, in the Case of Proclamations in 1611, Coke held that the Sovereign could only exercise those prerogatives he already had, and not create new ones. ${ }^{38}$ This did not, however, preclude the development and redefinition of prerogatives to suit changing conditions.

With the so-called Glorious Revolution, the House of Stuart fell, and William III became King of England. At the same time, the Bill of Rights 1689 (Eng.) ${ }^{39}$ was drafted, implementing in formal law the political reality of the Sovereign's growing subservience to Parliament. It specifically limited the royal prerogative, with Article 1 holding that the 'power of suspending the laws or the execution of laws by regal authority without consent of Parliament is illegal', and article 4 confirming that 'levying money for or to the use of the Crown by pretence of prerogative, without grant of Parliament, for longer time, or in other manner than the same is or shall be granted, is illegal'. The Bill also confirmed that Parliament had the right to limit the use of remaining prerogatives, as later shown by the Triennial Act 1694 (Eng.), ${ }^{40}$ which required the Sovereign to dismiss and call Parliament at certain times. ${ }^{41}$

Although most prerogatives are now exercised at the behest of ministers, some remain in the hands of the Sovereign. One of the Sovereign's prerogatives is - or was (in the United Kingdom) - the dissolution of Parliament, which is, in the words of Barnett, 'perhaps the most important residual prerogative exercised personally be the Sovereign, and presents the greatest potential for controversy'. ${ }^{42}$ This

35 Ibid, 561.

36 Prohibitions del Roy (1607) 12 Co. Rep. 63; 77 E.R. 1342 ('the Case of Prohibitions').

37 Ibid.

38 Case of Proclamations (1611) 12 Co. Rep. 74; 77 E.R. 1352 (K.B.).

391 Will. III \& Mary sess. 2 c. 2.

406 \& 7 Will. III \& Mary II c. 2.

41 Loveland, Ian, Constitutional Law, Administrative Law, and Human Rights: A Critical Introduction (5th edn., 2009), p. 91. The Triennial Act 1694, also known as the Meeting of Parliament Act 1694 (6 \& 7 Will.. \& Mar.. c.. 2), required Parliament to meet annually and to hold general elections once every three years.

42 Barnett, Hilaire, Constitutional \& Administrative Law (7th edn., 2009), p. 106. 
prerogative is normally exercised at the request of the Prime Minister, either at his or her discretion or following a motion of no confidence. The last time the Sovereign unilaterally dissolved Parliament was in 1835, when Earl Grey resigned as prime minister; although he had a fully functioning cabinet capable of carrying on without him, when King William IV chose to force it out of office.

Constitutional theorists have differing views as to whether this would be possible today (subject to the statutory reforms in the United Kingdom having now suppressed the prerogative with respect to dissolution); Jennings wrote that dissolution involves 'the acquiescence of ministers', and as such the Sovereign could not dissolve Parliament without ministerial consent; if ministers refuse to give such advice, she can do no more than dismiss them'. Dicey - a hundred years earlier - however, believed that in certain extreme circumstances the Sovereign could dissolve Parliament single-handedly, on the condition that

an occasion has arisen on which there is fair reason to suppose that the opinion of the House is not the opinion of the electors ... A dissolution is allowable, or necessary, whenever the wishes of the legislature are, or may fairly be presumed to be, different from the wishes of the nation. ${ }^{43}$

It is interesting that Dicey is better known today for his interpretation of the powers of the Crown which limit the discretion of the Sovereign than he is for those which impart an element of independence. It is, however, unlikely that he was correct in his view of the personal prerogative to dissolve Parliament. At least, even if he were right in the early twentieth century, this particular exercise of the prerogative is dead or dormant today. Under the Fixed-term Parliaments Act 2011 (U.K.), as amended, Parliament is dissolved automatically 25 working days ahead of a general election. Elections ordinarily take place five years after the previous general election, but may be held sooner if the Prime Minister loses a vote of confidence, or if two-thirds of the members of the House of Commons vote in favour of an early election. Under section 3(2), Parliament cannot otherwise be dissolved, and, in the United Kingdom, the prerogative with respect to dissolution, is abrogated.

The dissolution of the United Kingdom Parliament on 30 March 2015, to make way for the general election to be held on 7 May 2015, was the first time Parliament had ever dissolved automatically, as opposed to being dissolved by Royal Proclamation (although provision was made by the Septennial Act 1715 (G.B.) for Parliament to dissolve automatically after seven, and later five years, in practice dissolution was always effected shortly before the end of the five-year period by means of a Royal Proclamation). ${ }^{44}$

Section 3(1) of the Fixed-term Parliaments Act 2011 (U.K.) originally stated that Parliament should be automatically dissolved 14 working days before a

43 Ibid, p. 107.

44 In New Zealand, Parliament was, on at least one occasion, automatically dissolved, due to a miscalculation of the length of the parliamentary term. 


\section{Introduction}

polling day of a general election. This was subsequently amended by the Electoral Registration and Administration Act 2013 (U.K.) to 25 working days. Section 1 of the Act provides for such polling days to occur on the first Thursday in May of the fifth year after the previous general election, starting with 7 May 2015. The Prime Minister has the power, by order made by Statutory Instrument under section $1(5)$, to provide that the polling day is to be held up to two months later than that date. Such a Statutory Instrument must be approved by each House of Parliament.

Section 2 of the Act also provides for two ways in which a general election can be held before the end of this five-year period:

If the House of Commons resolves 'That this House has no confidence in Her Majesty's Government', an early general election is held, unless the House of Commons subsequently resolves 'That this House has confidence in Her Majesty's Government'. This second resolution must be made within fourteen days of the first.

If the House of Commons, with the support of two-thirds of its total membership (including vacant seats), resolves 'That there shall be an early parliamentary general election'.

In either of these two cases, the monarch (on the recommendation of the prime minister) appoints the date of the new election by proclamation. Parliament is then dissolved 25 working days before that date.

The Sovereign can theoretically force the dissolution of Parliament through a refusal of royal assent to legislation; this almost inevitably would lead to a government losing the confidence of the House of Commons. However, by convention, the Sovereign always assents to Bills. The last time the royal assent was not given was in 1708 during the reign of Queen Anne - and even then it was on the advice of ministers. This does not necessarily mean that the right to refuse has altogether died; King George V believed he could veto the Third Irish Home Rule Bill; Jennings wrote that 'it was assumed by the King throughout that he had not only the legal power but the constitutional right to refuse assent'. ${ }^{45}$ The distinction between a legal power and a constitutional right is of course central to this question. It may well be that the power of dissolution existed where the government lacks a parliamentary majority, but not otherwise.

The appointment of the Prime Minister is also governed by the royal prerogative. Technically, the Sovereign may appoint whoever he or she wishes as Prime Minister, but in practice the appointee is that person who commands a majority in the House of Commons. Usually, this is the leader of the political party which is returned to Parliament with a majority of seats after a general election. Difficulties may result with a so-called 'hung Parliament', where no party commands majority support. In this situation, constitutional convention is that the previous incumbent has the first right to form a coalition government and seek

45 Barnett, Hilaire, Constitutional \& Administrative Law (7th edn., 2009), p. 109. 
appointment. ${ }^{46}$ If the Prime Minister decides to retire in the middle of a parliamentary session, as Sir Anthony Eden did in 1957, the Sovereign has little scope for the exercise of discretion. There is usually a 'Prime Minister-in-waiting' who commands the support of the majority of the Commons; he or she will, in the words of Barnett, near-automatically be appointed. ${ }^{47}$ But that is not to say that there is no scope for personal discretion, particularly where there isn't an obvious successor. Normally, a Prime Minister will remain in office until their successor emerges, by whatever means their party has of resolving this.

The most noted prerogative power that affects the judicial system is the prerogative of mercy, which has two elements: the granting of pardons and the granting of nolle prosequi. Pardons may be used to eliminate the 'pains, penalties and punishments ${ }^{48}$ which come from a criminal conviction, although they do not (generally) remove convictions themselves. This power is commonly exercised, in the United Kingdom, on the advice of the Secretary of State for the Home Department; the Sovereign has no direct involvement in its use. Exercise of this power may also take the form of commutations, a limited form of pardon where the sentences is reduced, on certain conditions. The granting of a pardon is not subject to judicial review, as confirmed by Council of Civil Service Unions v. Minister for the Civil Service (generally known as the G.C.H.Q. case), ${ }^{49}$ but nonetheless the courts have chosen to criticise its application or lack thereof, as in R. v. Secretary of State for the Home Department, ex parte Bentley. ${ }^{50}$

Granting nolle prosequi is done by the Attorney-General of England and Wales (or the Scottish or Northern Irish equivalent) in the name of the Crown, to stop legal proceedings against an individual. This also was not reviewable by the courts, as confirmed by $R$. v. Comptroller of Patents, ${ }^{51}$ although newer cases suggest that this is no longer the situation, ${ }^{52}$ and as it does not count as an acquittal, the defendant may be brought before the courts on the same charge at a later date.

The prerogative is in much use in the realm of foreign affairs. It is the Sovereign who recognises foreign states (although several statutes regulate the immunities enjoyed by their heads and diplomatic representatives), issues declarations of war and peace, and enters into international treaties. The Sovereign also has the power to annex territory, as was done in 1955 with the island of Rockall. ${ }^{53}$ Once territory has been annexed, the Sovereign (through their ministers) has complete discretion as to what extent it will take over the former government's liabilities; this

46 Ibid, p. 114.

47 Ibid, p. 115.

48 R. v. Foster [1984] 2 All E.R. 679 (C.A.).

49 Council of Civil Service Unions v. Minister for the Civil Service [1985] A.C. 374 (H.L.).

$50 R$ v. Secretary of State for Home Department, ex parte Bentley [1994] Q.B. 349; [1993] 4 All E.R. 443.

51 R. v. Comptroller of Patents [1899] I Q.B. 909.

52 R. v. General Council of the Bar, ex parte Percival [1990] 3 All E.R. 137.

53 Though this power has also been questioned; Edeson, W.R., "The Prerogative of the Crown to Delimit Britain's Maritime Boundary” (1973) 89 L.Q.R. 364. 


\section{Introduction}

was confirmed in West Rand Central Gold Mining Company v. The King. ${ }^{54}$ The Sovereign also has the power to alter British territorial waters and cede territory. His or her freedom to do this in reality rather than theory is doubtful, in that it would involve depriving British citizens of their nationality and rights. When the island of Heligoland was ceded to Germany in 1890, parliamentary approval was first sought. ${ }^{55}$ The Sovereign can also regulate colonies and dependent territories by exercising the prerogative through Orders-in-Council. The courts have long fought the Sovereign's use of this power; in R. (Bancoult) v. Secretary of State for Foreign and Commonwealth Affairs, ${ }^{56}$ the Court of Appeal ruled that using Orders-in-Council to frustrate judicial rulings was an unlawful abuse of power, although this was later overturned in the House of Lords. ${ }^{57}$

Passports are also regulated by the prerogative, although there are statutory provisions. Under the common law, citizens have the right to freely leave and enter the United Kingdom, but under statute and in administrative practice it is extremely difficult to do so without a passport. In R. v. Foreign Secretary, ex parte Everett, ${ }^{58}$ the courts held that it was their right to review situations where a British citizen has been granted or withheld a passport. The writ of ne exeat regno was also used to prevent a person leaving the country, although it has recently been described as a 'charming historical relic but must be regarded as an anachronism given the availability of the modern form of order'. ${ }^{59}$ The right to form treaties is arguably a disputed prerogative power; under Blackstone's definition, a prerogative power must be one unique to the monarch. However, because a treaty cannot interface with United Kingdom law without an enabling Act of Parliament (such as the European Communities Act 1972 (U.K.)), the Sovereign alone cannot bring one into force. ${ }^{60}$ As recent case law establishes, nor can the Sovereign revoke such a treaty with the consent of Parliament, where such action would

54 West Rand Central Gold Mining Company v. The King [1905] 2 K.B. 391.

55 Loveland, Ian, Constitutional Law, Administrative Law, and Human Rights: A Critical Introduction (5th edn., 2009), p. 120.

$56 R$ (Bancoult) v. Secretary of State for Foreign and Commonwealth Affairs [2008] U.K. H.L. 61; [2008] 3 W.L.R. 955 (H.L.).

57 Ibid.

58 R. v. Foreign Secretary, ex parte Everett [1989] Q.B. 811, [1988] E.W.C.A. Civ. 7, [1989] 2 W.L.R. 224.

59 Bhura v. Bhura [2012] E.W.H.C. 3633 (Fam.), per Mostyn J.

60 Although the international approach varies between monist and dualist extremes, the United Kingdom is traditionally seen as exemplifying the dualist position, with treaties having no effect in domestic law unless incorporated by statute. However, where legislation is capable of two interpretations, one consistent with a treaty obligation and one inconsistent, then the courts will presume that Parliament intended to legislate in conformity with the treaty and not in conflict with it. Customary international law is considered to form part of the common law (see Keyu v. Secretary of State for Foreign and Commonwealth Affairs [2015] U.K.S.C. 69). It has been established that an international convention may be used as an aid to statutory interpretation, particularly when it comes to human rights, or be something to which the court can have regard in the exercise of judicial discretion (see Morgan v. Hinton Organics (Wessex) Ltd [2009] E.W.C.A. Civ. 107). 
involve changes to statute law. ${ }^{61}$ This would have the effect of requiring parliamentary involvement in almost every conceivable case, as few treaties would not have statutory implications.

The Sovereign also has power to exercise his or her prerogative over the granting of honours, the regulation of the armed forces and (for the established Church of England) ecclesiastical appointments. Although the granting of most honours is normally determined by the executive, the Sovereign is still the person who technically awards them. Exceptions to this rule are membership of the Order of the Garter, the Order of the Thistle, the Royal Victorian Order and the Order of Merit, which the Sovereign has complete discretion to grant. ${ }^{62}$ In relation to the armed forces, the Sovereign is the Commander-in-Chief, ${ }^{63}$ and members are regulated under the prerogative. ${ }^{64}$ Most statutes do not apply to the armed forces, although some areas, such as military discipline, are governed by specific Acts of Parliament. The Sovereign is the sole authority for the armed forces, and as such their organisation, disposition and control cannot be questioned by the courts. ${ }^{65}$ This exercise of prerogative power gives the Crown authority to recruit members of the armed forces, appoint commissioned officers, and establish agreements with foreign governments to station troops in their territory. ${ }^{66}$ The prerogative empowers the Sovereign to appoint bishops and archbishops in the Church of

61 R. (Miller) v Secretary of State for Exiting the European Union [2017] U.K.S.C. 5.

62 See Cox, Noel, "The Dichotomy of Legal Theory and Political Reality: The Honours Prerogative and Imperial Unity" (1998-1999) 14 Australian Journal of Law and Society 15-42.

63 The term 'Commander-in-Chief' has a loose and uncertain meaning. The Sovereign is, by virtue of that status and position, deemed to be commander-in-chief, although the term is rarely used (unlike in the United States of America, where is has assumed a life quite separately from that of the style of President, though the term Commander-inChief is likewise undefined, and indeed shares the same origins as that used by the British Sovereign). In New Zealand, it is stated in Defence Act 1990 (N.Z.), s. 5 that the Governor-General may from time to time, in the name and on behalf of the Sovereign, continue to raise and maintain armed forces. Although the precise effect of s. 6 is unclear, it states that the Governor-General, as Commander-in-Chief of New Zealand, shall have such powers as pertain to the office of Commander-in-Chief. He or she is appointed, under the Letters Patent Constituting the Office of Governor-General 1983 (S.R. 1983/225), amendments S.R. 1987/8, S.R. 2006/219, Governor-General and Commander-in-Chief. Elsewhere, Governors of separate colonies and GovernorsGeneral are habitually appointed Commander-in-Chief; in the Falkland Islands, after the recovery of the islands from Argentinian invaders, the positions of Governor and Commander-in-Chief were temporarily separated, with the commander of the garrison being appointed Commander-in-Chief.

64 However, the Bill of Rights 1688 (1 Will. \& Mary Sess. 2 c. 2) (Eng.) Art. 6 prohibits the 'raising and keeping a standing army within this kingdom, in time of peace, without consent of Parliament'. See Curtis v. Minister of Defence [2002] 2 N.Z.L.R. 744 (C.A.).

65 Loveland, Ian, Constitutional Law, Administrative Law, and Human Rights: A Critical Introduction (5th edn., 2009), p. 119.

66 Ministry of Justice, Review of the Executive Royal Prerogative Powers: Final Report (2009). 


\section{Introduction}

England, ${ }^{67}$ and to regulate the printing and licensing of the authorised Church of England version of the Bible. ${ }^{68}$

R. v. Secretary of State for the Home Department, ex parte Northumbria Police Authority, ${ }^{69}$ recognised that the prerogative also includes the power to 'take all reasonable steps to preserve the Queen's peace', and in Burmah Oil Co. (Burma Trading) Ltd v. Lord Advocate, ${ }^{70}$ the House of Lords took the view that it extended to 'doing all those things in an emergency which are necessary for the conduct of the [Second World] War'. ${ }^{71}$

Today, the Sovereign exercises the prerogative almost exclusively in accordance with the advice of her government. ${ }^{72}$ Leyland notes that:

The present Queen ... is kept very closely in touch with the exercise of governmental power by means of a weekly audience with the prime minister during which she is fully briefed about the affairs of government ... [But it] should be emphasised that the prime minister is not under any obligation to take account of royal opinions. ${ }^{73}$

In simple terms, the prerogative is used to govern the United Kingdom and the realms in the name of the Crown; although the Sovereign has the 'right to be consulted, the right to encourage, and the right to warn', ${ }^{74}$ his or her role - at least in normal circumstances - involves no personal exercise of discretion. ${ }^{75}$

Prerogative powers were formerly exercised by the Sovereign acting alone, and later on the advice of ministers. Since the nineteenth century, the advice of the Prime Minister or the cabinet - who are then accountable to Parliament for the decision has been required in order for the prerogative to be exercised. The Sovereign is constitutionally empowered to exercise the royal prerogative against the advice of the Prime Minister or the cabinet, ${ }^{76}$ but does so only in emergencies or where existing precedent does not adequately apply to the circumstances in question.

67 See Cox, Noel, "The nature of ministerial authority in the Anglican Church in New Zealand" (2005) 119(2) Churchman 105-136; Cox, Noel, Church and State in the Post-Colonial Era: The Anglican Church and the Constitution in New Zealand (2008).

68 Though based on statutory authority also; Appointment of Bishops Act 1533 (25 Hen. VIII c. 20) (Eng.), ss. 3-5 (amended by the Statute Law Revision Act 1888 (U.K.)); Cathedrals Measure 1931 (21 \& 22 Geo. V no. 7) (U.K.), s. 23 (repealed).

$69 R v$. Secretary of State for the Home Department, ex parte Northumbria Police Authority [1989] Q.B. 26; [1988] l All E.R. 556 (C.A.).

70 Burmah Oil Co. (Burma Trading) Ltd v. Lord Advocate [1965] A.C. 75 (H.L.).

71 Ibid.

72 Wade, Sir Henry, Q.C. \& Bradley, A.W., Constitutional and Administrative Law (11th edn., 1993), pp. 244-245, 261-264; de Smith, S.A. \& Rodney Brazier, Constitutional and Administrative Law (7th edn., 1994), pp. 139-142.

73 Leyland, Peter \& Gordon Anthony, Textbook on Administrative Law (6th edn., 2007), p. 74 .

74 Bagehot, Walter, "The English Constitution" in The Collected Works of Walter Bagehot, ed. Norman St. John-Stevas (1974), Vol. 5.

75 Ibid.

76 Bagehot, Walter, The English Constitution (2001), p. 111. 
Today, the royal prerogative is concerned with several areas critical to the government of the United Kingdom (and other states), including the conduct of foreign affairs, defence and national security. The Sovereign has a significant constitutional presence in these and other areas, but very limited power, because the prerogative is nowadays in the hands of the Prime Minister and other ministers or other government officials.

Some key functions of the British Government are still executed by virtue of the royal prerogative, but generally the usage of the prerogative has been diminishing as functions are progressively put on a statutory basis. ${ }^{77}$

The courts have jurisdiction to look into the existence or extent of any alleged prerogative, ${ }^{78}$ it being a maxim of the common law that 'the King ought to be under no man, but under God and the law, because the law makes the King' ${ }^{79}$ If any prerogative is disputed, the courts must decide the question whether or not it exists in the same way as they decide any other question of law. If a prerogative is clearly established, they must take the same judicial notice of it as they take of any other rule of law. ${ }^{80}$

\section{See Chapter 7.}

78 The instances in the books are numerous. For examples of cases where the courts have determined the extent of prerogative rights, see Darcy v. Allen (1602) 11 Co. Rep. 84b ('the Case of monopolies') (monopolies); Case of Monopolies, East India Co. v. Sandys (1685) 10 State Tr. 371 (exclusive trading licences). For a recent decision, see R. v. Secretary of State for the Home Department, ex parte Northumbria Police Authority [1989] Q.B. 26; [1988] I All E.R. 556 (C.A.), where the Home Secretary's decision to issue the police with CS gas and plastic baton rounds to deal with serious public disorder was upheld by the Court of Appeal, even though the police authority had refused to approve the supply. It was held that the policy could be justified by virtue of the Crown's prerogative power to act to meet an actual or apprehended breach of the peace. For an article critical of this decision see Bradley, A.W., "Police Powers and the Prerogative" [1988] Public Law 298.

79 I.e. rex non debet esse sub homine, sed sub Deo et lege, quia lex facit regeni: Bracton, lib. I, c. 8; 12 Co. Rep. 65; Fleta 2 c. 5; Chitty, Joseph, A Treatise on the Law of the Prerogatives of the Crown; And the Relative Duties and Rights of the Subject (1978), p. 5.

80 'We are indeed bound to take notice of everything that belongs to the Queen's privilege': Elderton's Case (1703) 2 Ld. Raym. 978, 980 per Holt C.J.; 'but if officers of the Crown claim procedural privileges by virtue of the prerogative, they must make out clearly the prerogative': Attorney-General to Prince of Wales v Crossman (1866) L.R. 1 Exch. 381, 386 per curiam. The courts cannot broaden the prerogative: see B.B.C. v. Johns (Inspector of Taxes) [1965] Ch. 32, 79; [1964] l All E.R. 923, 941 per Diplock L.J. (C.A.). In a classical summary of the subject Frederic Maitland, The Constitutional History of England - a course of lectures ed. H.A.L. Fisher (1980, first published 1908), pp. 418-421 said there is often great uncertainty as to the exact limits of the royal prerogative. Although there is no such doctrine that a prerogative may cease to exist because it is not used, many old prerogative powers, even if not actually abolished by statute, have become clumsy and antiquated and have fallen into disuse. The Crown usually prefers to act under definite statutory powers. See also de Smith, S.A. \& Rodney Brazier, Constitutional and Administrative Law (7th edn., 1994), pp. 144-145. For an article expressing doubts as to a prerogative power, see Edeson, W.R., "The Prerogative of the Crown to Delimit Britain's Maritime Boundary" (1973) 89 L.Q.R. 364; and Bradley, A.W., "Police Powers and the Prerogative" [1988] Public Law 298. 


\section{Introduction}

There have been several influential decisions of the House of Lords, and now the Supreme Court, which have significantly limited the freedom of use of prerogatives. In 1915, the Lords decided Re Petition of Right, ${ }^{81}$ which concerned the British Army's seizure of a commercial airfield for military purposes during wartime. The government argued it was to defend against an invasion; the courts held that for the prerogative to be exercised, the government must demonstrate that an invasion situation exists; this was a remarkable instance of the courts departing from the rule of restraint which kept them from making determinations on purely or primarily political questions or matters of high policy. This was backed up by The Zamora, ${ }^{82}$ where the Judicial Committee of the Privy Council held generally that to exercise a power not granted by statute (such as a prerogative) the government must prove to the court that the use is justified. ${ }^{83}$ The next limitation came in Attorney-General v. De Keyser's Royal Hotel Ltd, ${ }^{84}$ where the House of Lords confirmed that no new prerogative powers could be created, ${ }^{85}$ and that a statutory provisions in an area where prerogative powers are in use 'abridges the Royal Prerogative while it is in force to this extent - that the Crown can only do the particular thing under and in accordance with the statutory provisions, and that its prerogative power to do that thing is in abeyance'. ${ }^{86}$

This principle of statutory and indeed judicial superiority was extended in Laker Airways Ltd v. Department of Trade, ${ }^{87}$ where it was confirmed that prerogative powers could not be used to frustrate a statutory provision, and that in situations where the power and the statute were designed to be used side by side, the power could only be used to further the aim of the statute. Another extension came with R. v. Secretary of State for the Home Department, ex parte Fire Brigades Union, ${ }^{88}$ where the Court of Appeal held that even if a statute (in this case the Criminal Justice Act 1988 (U.K.)) had not yet come into force, the prerogative could not be used to alter this statute to 'conflict with Parliament's wishes' ${ }^{89}$ This was unusual, in that the statute had been passed, but the relevant provisions required a commencement order to come into effect. The court did not decide that passing legislation created a statutory duty for the Secretary of State to bring the provisions of the Act into force at any particular time, and indeed the Criminal Justice Act 1988 (U.K.) was subsequently repealed, having never been in force, and replaced by the Criminal Injuries Compensation Act 1995 (U.K.).

81 Petition of Right, In re a [1915] 3 K.B. 649 ('the Shoreham Aerodrome case').

82 The Zamora [1916] 2 A.C. 77; 32 T.L.R. 436 (P.C.).

83 Loveland, Ian, Constitutional Law, Administrative Law, and Human Rights: A Critical Introduction (5th edn., 2009), p. 93.

84 Attorney-General v. De Keyser's Royal Hotel Ltd [1920] A.C. 508 (H.L.).

85 Ibid.

86 Loveland, Ian, Constitutional Law, Administrative Law, and Human Rights: A Critical Introduction (5th edn., 2009), p. 97.

87 Laker Airways Ltd v. Department of Trade [1977] Q.B. 643 (C.A.).

88 R. v. Secretary of State for the Home Department, ex parte Fire Brigades Union [1995] 2 A.C. 513, [1995] l All E.R. 888 (C.A.).

89 Ibid. 
Despite these cases, the courts were traditionally unwilling to subject prerogative powers to judicial review. Judges were only willing to state whether or not powers existed, not whether they had been used appropriately. ${ }^{90}$ The courts therefore applied only the first of the Wednesbury tests; ${ }^{91}$ namely, whether the use was illegal. Constitutional scholars such as Blackstone would have probably considered this appropriate:

In the exertion therefore of those prerogatives, which the law has given him, the King is irresistible and absolute, according to the forms of the constitution. And yet if the consequence of that exertion be manifestly to the grievance or dishonour of the kingdom, the Parliament will call his advisers to a just and severe account. ${ }^{92}$

Accountability was therefore political rather than legal.

Until recently the courts would not enquire into the way in which a prerogative power had been exercised. ${ }^{93}$ During the 1960s and 70s, the attitude of the courts began to change, ${ }^{94}$ with the development of the scope of judicial review, ${ }^{95}$ and

90 Attorney-General v. De Keyser's Royal Hotel Ltd [1920] A.C. 508 (H.L.).

91 Based on Associated Provincial Picture Houses Ltd v. Wednesbury Corporation [1948] $1 \mathrm{~K}$. B. 223.

92 Loveland, Ian, Constitutional Law, Administrative Law, and Human Rights: A Critical Introduction (5th edn., 2009), p. 102.

93 See China Navigation Co. Ltd. v Attorney-General [1932] 2 K.B. 197 (C.A.) (manner of disposition of armed forces); Blackburn v Attorney-General [1971] 2 All E.R. 1380; [1971] 1 W.L.R. 1037 (C.A.) (entry into a treaty); Hanratty v. Lord Butler of Saffron Walden (1971) 115 Sol. Jo. 386 (prerogative of mercy); Gouriet v. Union of Post Office Workers [1978] A.C. 435; [1977] 3 All E.R. 70 (H.L.) (Attorney-General's consent to the bringing of relator actions).

94 Examples of successful challenges to the exercise of powers conferred by royal prerogative include R. v. Secretary of State for the Home Department, ex parte Ruddock [1987] 2 All E.R. 518; [1987] 1 W.L.R. 1482 (the court acknowledged jurisdiction to examine the issue of a warrant to intercept telephones); $R$. v. Secretary of State for Foreign and Commonwealth Affairs, ex parte Everett [1989] Q.B. 811; [1989] 1 All E. R. 655 (C.A.) (refusal of a passport); R. v. Secretary of State for the Home Department, ex parte Bentley [1994] Q.B. 349; [1993] 4 All E.R. 442 (D.C.) (mercy: refusal of a posthumous free pardon); Attorney-General of Trinidad and Tobago v. Phillip [1995] 1 A.C. 396; [1995] 1 All E.R. 93 (P.C.). See also R. v. Secretary of State for the Home Department, ex parte R.P. and T.G. [1994] C.O.D. 507 (C.A.) (refusal by Criminal Injuries Compensation Board to make an award for an offence of sexual abuse by a parent of a child committed before 1979, when compensation for offences committed 'under the same roof' was not recoverable); R. v. Secretary of State for the Home Department, ex parte Fire Brigades Union [1995] 2 A.C. 513; [1995] 2 All E.R. 244 (H.L.) (refusal of Secretary of State to bring statutory provisions into force). The exercise of the prerogative of mercy under the Constitution of the Bahamas, arts. 90 and 92 in death sentence cases was not amenable to judicial review: Reckley 1 . Minister of Public Safety and Immigration (No. 2) [1996] I A.C. 527; [1996] I All E.R. 562 (P.C.); following De Freitas v Benny [1976] A.C. 239; [1975] 3 W.L.R. 388 (P.C.).

95 As to judicial review, see Civil Procedure Rules 1998 (S.I. 1998/3132) (formerly R.S. C. Ord. 53). 
the courts have been more willing to review the exercise of discretionary power, whether derived from statute or common law, and hence the courts may be willing to review exercises of the prerogative. ${ }^{96}$ The test for reviewability of a prerogative is not the source of the power, but the nature of the function to which it relates and whether it is justiciable. ${ }^{97}$

In R. v. Criminal Injuries Compensation Board, ex parte Lain, ${ }^{98}$ the courts held that prerogative powers could be reviewed if they were being used to perform a 'judicial' task; the issues at hand were ones that the courts were easily able to decide. Laker Airways Ltd v. Department of Trade lent further weight to the idea that prerogative powers should be subject to stronger judicial review, with Lord Denning saying that 'seeing that the prerogative is a discretionary power to be exercised for the public good, it follows that its exercise can be examined by the courts just as any other discretionary power which is vested in the executive'. 99 The most authoritative case on the matter is the G.C.H.Q. case. ${ }^{100}$ The House of Lords confirmed that the application of judicial review would be dependent on the nature of the government's powers, not their source. Foreign policy and national security powers were considered outside the scope of judicial review, while the prerogative of mercy is considered within it, as in R. v. Secretary of State for the Home Department, ex parte Bentley. ${ }^{101}$

96 See R. v. Criminal Injuries Compensation Board, ex parte Lain [1967] 2 Q.B. 864; [1967] 2 All E.R. 182 (C.A.) (award by Criminal Injuries Compensation Board, set up under the prerogative, held subject to judicial scrutiny by way of certiorari); Laker Airways Ltd v. Department of Trade and Industry [1977] Q.B. 643; [1977] 2 All E.R. 182 (C.A.) (withdrawal of designation of airline to operate a transatlantic service); Council of Civil Service Unions v. Minister for the Civil Service [1985] A.C. 374; [1984] 3 All E.R. 935 (H.L.).

97 The most important case in relation to this development has been Council of Civil Service Unions v. Minister for the Civil Service [1985] A.C. 374; [1984] 3 All E.R. 935 (H.L.), in which the Secretary of State for the Foreign and Commonwealth Office decided to exclude trade unions from Government Communications Headquarters (G.C.H.Q.), where civil servants were employed. The House of Lords held that such action was in principle reviewable because it concerned the terms of employment of people who, prima facie, had a legitimate expectation that advantages which they had hitherto enjoyed would not be discontinued without their being consulted. The Secretary of State's invocation of the interests of national security, however, served to remove his decision from judicial scrutiny. Lord Roskill thought that the right of challenge was not unqualified. 'It must, I think, depend on the subject matter of the prerogative power which is exercised. Many examples were given during the argument of prerogative powers which as at present advised I do not think could properly be made the subject of judicial review. Prerogative powers such as those relating to the making of treaties, the defence of the realm, the prerogative of mercy, the grant of honours, the dissolution of Parliament and the appointment of ministers as well as others are not, I think, susceptible to judicial review because their nature and subject matter are such as not to be amenable to the judicial process' (418 and 956 per Lord Roskill). See also R. v. Secretary of State for Foreign and Commonwealth Affairs, ex parte Butt [1999] C.O.D. 470 (C.A.).

98 R. v. Criminal Injuries Compensation Board, ex parte Lain [1967] Q.B. 864 (C.A.).

99 Laker Airways Ltd v. Department of Trade [1977] Q.B. 643 (C.A.).

100 Council of Civil Service Unions v. Minister for the Civil Service [1985] A.C. 374 (H.L.).

$101 R$ v. Secretary of State for Home Department, ex parte Bentley [1994] Q.B. 349; [1993] 4 All E.R. 443. 
As may be seen from the above, the prerogative is both extensive in scope and also constrained by political reality, by Parliament, and the uncertain control of the courts. Former left-wing Labour M.P. Tony Benn campaigned unsuccessfully for the abolition of the royal prerogative in the United Kingdom in the 1990s, arguing that all governmental powers in effect exercised on the advice of the prime minister and cabinet should be subject to parliamentary scrutiny and require parliamentary approval. The Ministry of Justice undertook a 'Review of executive Royal Prerogative powers' in October 2009. ${ }^{102}$ Later the government argued that such is the breadth of topics covered by the royal prerogative that requiring parliamentary approval in each instance where the prerogative is currently used would overwhelm parliamentary time and slow the enactment of legislation. ${ }^{103}$ However, it remains important to understand, not merely what comprises the prerogative, but also its nature and form, in order to prepare for any possible reform or abolition, and to make better use of the existing governmental powers, privileges and immunities.

The royal prerogative, based as it is on the common law rather than statute, has been described as a 'black hole' of unaccountable authority at the heart of the constitution. ${ }^{104}$ This work seeks to show that, whilst it is something of an enigma, in the sense that it remains uncertain in detail, the flexibility and historic legitimacy of the royal prerogative, combined with its increasing reviewability by the courts, means that it is neither unaccountable nor obsolete; its separation from the authority of the legislature is the very source of its legitimacy and continued relevance. Given the expansion of the scope and reach of judicial review, and parliamentary accountability, of the royal prerogative, it is also not unaccountable.

The approach taken to this task is to canvas the familiar territory covered by Blackstone, Chitty and Dicey, while seeking to ascertain, not the specific attributes and powers, but the sources and justifications for such powers. In so doing a more historically sound classification of the prerogative powers is possible, as well as a clearer understanding of the justification for specific powers and for the prerogative itself.

Throughout the work, the terms 'King' and 'Queen' are used interchangeably, with Queen taken to mean Queen regnant, unless the meaning is otherwise defined; 'Sovereign' or 'monarch' likewise are used, unless the context suggests otherwise, without distinction. Similarly, the term 'Crown' is used to refer to the institution, whether it is seen as a corporation sole or corporation aggregate, of which the Sovereign is the personal, human, manifestation. Likewise, the masculine includes the feminine and vice versa, and the singular the plural, as appropriate.

102 Ministry of Justice, Review of the Executive Royal Prerogative Powers: Final Report (2009).

103 McKie, David, "How ministers exercise arbitrary power", The Guardian (London, 6 December 2000) <https://www.theguardian.com/uk/2000/dec/06/monarchy. comment4> Retrieved 11 September 2017.

104 Poole, Thomas, "United Kingdom: The Royal Prerogative" (2010) 8(1) I•CON $146-155$. 


\section{Bibliography}

\section{Primary sources}

Beattie, Hon. Sir David, former Governor-General of New Zealand, 15 April 1998.

\subsection{Interviewees}

Benwell, Philip, National Chairman, Australian Monarchist League, 2-6 November 1999.

Boston, Professor Jonathon, Faculty of Commerce and Administration, Victoria University of Wellington, 15 April 1998.

Bousfield, Arthur, Vice-Chairman, Monarchist League of Canada, 9-20 September 1999.

Darby, Michael, Secretary, Queenslanders for Constitutional Monarchy, 23 November-4 December 1998.

Dicks, Randal, Governor, Constantian Society (U.S.A.), 15-16 November 1998.

Foreman, Donald, Secretary-General, Constitutional Monarchy Association, 16-22 November 1998, 9-22 September 1999.

Graham, Rt. Hon. Sir Douglas, former Minister in Charge of Treaty of Waitangi Negotiations, New Zealand, 24 November 1999.

Jones, Mrs Kerry, Executive Director, Australians for Constitutional Monarchy, 16 November 1998.

Judd, Hugo, Official Secretary to the Governor-General of New Zealand, 14 April 1998.

Keith, Rt. Hon. Sir Kenneth, Judge of the Court of Appeal of New Zealand, 16 April 1998.

Ladley, Dr Andrew, Faculty of Law, Victoria University of Wellington, 16 April 1998.

Lange, Rt. Hon. David, former Prime Minister of New Zealand, 20 May 1998.

McLeay, Associate Professor Elizabeth, Department of Politics, Victoria University of Wellington, 15 April 1998.

Morgan, Senhor Alan Assumpçao, Vice President, Brasil Imperial, 7-9 September 1999.

Reeves, Rt. Rev'd. and Hon. Sir Paul, former Governor-General of New Zealand, 11 November 1998.

te Heuheu, Hon. Georgina, former Associate Minister in Charge of Treaty of Waitangi Negotiations, New Zealand, 7 December 1999.

Tizard, Hon. Dame Catherine, former Governor-General of New Zealand, 19 May 1998.

\subsection{Manuscript: personal}

Hodge, William, "The Governor-General: The Evolution of the Office" (Paper presented to the Medico-Legal Society, Auckland, 13 September 1988).

McGarvie, Richard, "Our Democracy in Peril" (30 April 1997).

McGarvie, Richard, "The McGarvie Proposal for a Republican Equivalent of our Present System of Democracy" (1997).

Martin, Ged, "Freedom Wears a Crown: The Republican Non-Issue in Canada" (Paper presented at the High Commission for Australia, London, September 1994). 
Miller, Raymond, "God Save the Queen: The Republican Debate and Attitudes towards the Monarchy in New Zealand" (Paper presented to the Australasian Political Science Association Conference, Flinders University, Adelaide, 29 September 1997).

Moore, Mike, "Explanation: New Zealand Constitutional [People's] Convention Bill 1998" (11 February 1998).

Sharman, Campbell, "Defining Executive Power: Constitutional Reform for Grown-ups" (Australian Senate Occasional Lecture Series, Parliament House, Canberra, 22 November 1996).

Walker, Neil, "A Monarchy for Today" (c.1994).

Williams, Rev'd. David, "Reception of the Common Law in New Zealand", Conference on the Common Law in Asia, University of Hong Kong, 15-17 December 1986.

\subsection{Manuscript: official}

Government of Tuvalu, "Statement of Government Policy" (Speech from the Governor-General, Government of Tuvalu, Funafuti, 1996).

Governor-General of New Zealand, "Governor-General as Visitor, a Procedure for Dealing with Petitions" (Government House, Wellington, 1987).

Hardie Boys, Sir Michael, "A Resurrection of Leadership" (Guest Editorial, Otago Daily Times, Easter 1999).

Hardie Boys, Sir Michael, "Building a Civil Society" (N.Z. Education Development Foundations Seminar, Christchurch, 18 September 1999).

Hardie Boys, Sir Michael, "Should New Zealand be a dictatorship?" (Auckland Club Black Tie Dinner, Auckland, 7 September 1999).

Hardie Boys, Sir Michael, "Speech at the opening of Wharenui Tupai Martinborough" (25 October 1997).

Hardie Boys, Sir Michael, "Speech to the Public Law Class" (College House Christchurch, 10 September 1997).

Hardie Boys, Sir Michael, “The Constitutional Challenges of M.M.P.: A Magical Demystification Tour" (Institute of Policy Studies Seminar, Victoria University of Wellington, 3 December 1998).

Hardie Boys, Sir Michael, "The Role of the Governor-General under M.M.P." (Address to the Annual Dinner of the Institute of International Affairs, Wellington, 24 May 1996).

Keating, Paul, "The Way Forward" (Questions and Answers, Statement tabled in Parliament, 7 June 1995).

Mallory, J.R., "Some Constitutional Implications of Bill C-60: Part VI" (Submission to the Joint Special Committee of the Senate and the House of Commons on the Constitution of Canada, Records of the Governor General's Office, 1990-1991/016, box 13, file 535.1, Vol. 1).

“The Royal Victorian Order" (Fact Sheet H-5, Information Services, Government House, Ottawa, 1993).

\subsection{Government records and reports}

Attenborough, F.L. (ed. \& trans.), Laws of the earliest English kings (Cambridge University Press, Cambridge, 1922).

Auditor General, Federal Government Reporting Study: A Joint Study by the Office of Auditor General of Canada and the United States Government Administration Office (Auditor General's Office, Ottawa, 1986). 
Australian Electoral Commission, Referendum 1999 Results and Statistics (Australian Electoral Commission, Canberra, 2000).

British Public Papers - Colonies, New Zealand (Irish University Press, Shannon, 1970), Sessions 1835-1842.

Byers, M.H., Opinion on the Governor-General's Instructions (Australian Commonwealth Solicitor-General's opinion, 5 September 1975).

Cabinet Office, The Cabinet Manual. A guide to laws, conventions and rules on the operation of government (October 2011).

Canada, Sessional Papers No. 20 (1895).

Canadian Bar Association Committee on the Constitution, Towards a New Canada (Canadian Bar Association, Ottawa, 1978).

Corpus Iuris Canonici 1917.

Corpus Iuris Canonici 1983.

Department of Justice, Constitutional Reform - Reports of an Officials Committee (Government Printing Office, Wellington, 1986).

Exchange of Notes concerning the termination of special treaty relations between the United Kingdom and the Trucial States, 1 December 1971, Cmnd. 4941, U.K. Treaty Series 34 (1972).

Evidence of the Report of the Select Committee on Parliamentary Questions (H.C. 393, 1971-1972).

For the People, By the People (2007), Policy Paper No. 83, paras. 5. 8-5. 8.3.

Foreign Affairs Committee (House of Commons), First Report, Session 1980-81 (H.C. 42), British North America Acts: The Role of Parliament, vols. 1 and 2 (H.M.S.O., London, 1981).

Foreign Affairs Committee (House of Commons), First Report, Session Second Report, Session 1980-81 (H.C. 295), Supplementary Report on the British North America Acts: The Role of Parliament (H.M.S.O., London, 1981).

Foreign Affairs, Defence and Trade Committee, Report of the Foreign Affairs, Defence and Trade Committee on Inquiry into Parliament's Role in the International Treaty Process (Government Printer, Wellington, 1997), I.4A.

Forsey, Eugene, "Constitutional Monarchy and the Provinces" in Ontario Advisory Committee on Confederation, Background Papers and Reports (Queen's Printer, Toronto, 1967).

The Governance of Britain (July 2007), Cm. 7170.

The Governance of Britain - Draft Constitutional Renewal Bill (March 2008), Cm. 7342-11.

The Governance of Britain - War Powers and Treaties: Living Executive Powers (October 2007), C.P. 26/07.

House of Commons Public Administration Select Committee, Taming the Prerogative: Strengthening Ministerial Accountability to Parliament (House of Commons Public Administration Select Committee, London, 2004), Fourth Report of Session 2003-2004, H.C. 422.

Imperial Conference, Parliamentary Papers, Vol. 14, 1930-1931, Cmd. 3717.

Inter-Imperial Relations Committee, Imperial Conference, Parliamentary Papers, Vol. xi, 1926, Cmd. 2768.

International Convention on Salvage (28 April 1989); S. Treaty Doc. No. 102-112 (1991); 1953 U.N.T.S. 193.

Law Reform Commission of British Columbia, Legal Position of the Crown (The Law Reform Commission of British Columbia, Vancouver, 1972). 
Law Reform Commission of Canada, The Legal Status of the Federal Administration (Law Reform Commission of Canada, Ottawa, 1985).

Ministers' Powers, Committee on, Report of Committee on Ministers' Powers (1932), Cmd. 4060 .

Ministry of Justice, Review of the Executive Royal Prerogative Powers: Final Report (Ministry of Justice, London, 2009).

New Zealand 1990 Commission, The Treaty of Waitangi: The symbol of our life together as a nation (New Zealand 1990 Commission, Wellington, 1989).

Political and Constitutional Reform Committee, Parliament's role in conflict decisions, Eighth Report of Session 2010-2012, H.C. 923, 17 May 2011.

Political and Constitutional Reform Committee, Role and powers of the Prime Minister, First Report of Session 2014-2015, H.C. 351, 24 June 2014.

Prime Minister's Honours Advisory Committee, The New Zealand Royal Honours System: Report of the Prime Minister's Honours Advisory Committee (Department of the Prime Minister and Cabinet, Wellington, 1995).

Quentin-Baxter, Dame Alison, Review of the Letters Patent 1917 Constituting the Office of Governor-General of New Zealand (Prime Minister's Department, Wellington, 1980).

Report of the Conference on the Operation of Dominion Legislation and Merchant Shipping Legislation (1929), Cmd. 3479.

Report of the Inter-Imperial Relations Committee, Imperial Conference, Parliamentary Papers, Vol. xi, 1926, Cmd. 2768.

Report of the Joint Committee of the House of Lords and House of Commons on the Draft Constitutional Renewal Bill (31 July 2008), H.L. Paper 166-I/H.C. Paper 551-I.

Report of the Justice and Law Reform Committee on the Imperial Laws Application Bill (1988), Explanatory Material.

Report on Public Income and Expenditure, Parliamentary Papers, 1868-1869.

Report of the Privy Council on the project of a Bill for the better government of the Australian Colonies, dated 1 May 1849.

Report of the Waitangi Tribunal on the Kaitunga River Claim (Waitangi Tribunal, Wellington, 1984), Wai. 4.

Republican Advisory Committee Australia, An Australian Republic: The Options (the Turnbull Report) (Australian Government Publishing Service, Canberra, 1993).

Royal Commission on the Electoral System, Report of the Royal Commission on the Electoral System "Towards a better democracy" (Government Printer, Wellington, 1986).

Secretary of the Cabinet, Cabinet Office Mamual (Cabinet Office, Wellington, 1988, 1996).

Senate of Canada, Special Senate Committee on the Constitution, Proceedings of the Special Committee on the Constitution (1978), 9 August 1978, 3:12.

Senate Standing Committee on Legal and Constitutional Affairs, The doctrine of the shield of the Crown (Parliament of Commonwealth of Australia, Canberra, 1992).

"The Statute of Westminster: Notes on the Purpose and Effect of the Adoption by New Zealand Parliament of Sections 2, 3, 4, 5 and 6 of the Statute of Westminster and the New Zealand Constitution Amendment (Consent and Request) Bill in New Zealand" (Journals of the House of Representatives, lst Session, 28th Parliament, 1948), Appendix, Vol. 1.

The Title of the Sovereign (1953), Cmd. 8748. 


\subsection{Early works}

Anonymous of Rouen, Die Texte des Normannischen Anonymous ed. K. Pellens (Franz Steiner Verlag, 1966).

Aquinas, St. Thomas, Summa Theologiae eds. J. Gilbey et al (Blackfriars, McGaw-Hill, Eyre \& Spottiswoode, London, 1964-1980), 61 Vols.

Aristotle, Ethica Nicomachea eds. R.A. Gauthier \& E.J. Brill (de Brouwer, 1972-1974).

Ascham, Anthony, Of the Confusions and Revolutions of Government (London, 1649).

Assheton, William, The Royal Apology or, An Answer to the Rebels Plea: Wherein. The Most Noted Anti-Monarchical Tenents, First, Published by Doleman the Jesuite, to promote a Bill of Exclusion against King James. Secondly, Practised by Bradshawe and the Regicides in the Actual Murder of King Charles the 1st. Thirdly, Republished by Sidney and the Associators to Depose and Murder his present Majesty, Are distinctly considered. With a parallel between Doleman, Bradshawe, Sidney and others of the True-Protestant Party (London, 1684).

Bacon, Francis, The Letters And Life Of Francis Bacon (Longman, Green, Longman, and Roberts, London, 1861).

Bacon, Mathew, A New Abridgment of the Law (John Bouvier, Philadelphia, 1842, first published 1768).

Bennet, Robert, King Charle's Trial Iustified (London, 1649).

Blackstone, Sir William, Commentaries on the Laws of England ed. E. Christian (reprint by Garland Publishing, New York, 1978, 4th edn., Clarendon Press, Oxford, 1770, first published 1765).

Bodin, Jean, Les Six Livres de la Republique (The Six bookes of a Commonwealth) trans. M.J. Tooley (Blackwell, Oxford, 1955).

Bracton, de, Henry, On the Laws and Customs of England (Henri de Bracton de Legibus et Constuetudinibus Anglia) ed. G.E. Woodbine; trans. S.E. Thorne (Belknap Harvard, Cambridge, Massachusetts, 1968, first published c.1235).

Chalmers, George, Opinions of Eminent Lawyers on Various Points of English Jurisprudence (Reed \& Hunter, London, 1814).

Chitty, Joseph, A Treatise on the Law, Classics of English Legal History in the Modern Era (Garland Publishing, New York, 1978) (reprint of the 1820 edition published by Joseph Butterworth and Son, London, under the title: A Treatise on the Law of the Prerogatives of the Crown; And the Relative Duties and Rights of the Subject).

Chitty, Joseph, Treatise on the law of the prerogatives of the Crown and the relative duties and rights of the Subject (Gregg, London, 1969).

Chrimes, Stanley \& A.L. Brown, Select Documents of English Constitutional History 1307-1485 (A. \& C. Black, London, 1961).

Cobbett, William (ed.), The Parliamentary History of England (London, 1806-1820).

Coke, Sir Edward, Coke upon Littleton (reprint by Garland Publishing, New York, 1979 of 19th edn., 1832).

Coke, Sir Edward, The Second Part of the Institutes of the Laws of England; Containing the Exposition of Many Ancient and Other Statutes (5th edn., printed by John Streater, Henry Twyford, Elizabeth Flesher, assigns of Richard Atkyns, and Edward Atkyns, Esquires, London, 1671).

Coke, Sir Edward, 4th Institutes of the Laws of England (Garland Publishing, New York, 1979).

Coke, Sir Edward, The twelfth part of The reports of Sir Edward Coke, Kt.: of divers resolutions and judgments given upon solemn arguments, and with great deliberation and 
conference with the learned judges in cases of lavv, the most of them very famous, being of the Kings especiall reference from the council table, concerning the prerogative: as for the digging of salt-peter, forfeitures, forrests, proclamations, orc.: and the jurisdictions of the Admiralty, Common Pleas, Star-Chamber, High Commission, Court of Wards, Chancery of c.: and expositions and resolutions concerning authorities, both ecclesiastical and civill, within this realme: also the formes and proceedings of Parliaments, both in England, o Ireland: with an exposition of Poynings Law: with alphabetical tables, wherein may be found the principall matters contained in this book (Henry Twyford and Thomas Dring, London, 1658).

Comber, Rev'd. Thomas, Religion and Loyalty Supporting each other (Robert Clavel, London, 1681).

Comyns, Sir John \& A. Hammond, A Digest of the Laws of England (5th edn., Collins \& Hannay, London, 1822).

Constable, Henry, Discovery of A Counterfecte Conference (Collen, 1600).

Craig, Sir Thomas, The Right of Succession to the Kingdom of England (London, 1703, first published 1602).

Doleman, R. (pseudonym for Fr. Robert Parsons), Conference About the Next Succession (1594).

Ellesmere, Lord, "Observations on Coke's Reports", in L.A. Knafla, Law and Politics in Jacobean England (Cambridge University Press, Cambridge, 1977).

Filmer, Sir Robert, Patriarcha and other writings ed. J.P. Sommerville (Cambridge University Press, London, 1991).

Finch, Sir Henry, Discourse on the Law (printed by Henry Lintot, Law-Printer to the King's most excellent Majesty, and sold by D. Browne, without Temple-Bar; and J. Shuckburgh, next Richard's Coffee-house, Fleet-Street, reprinted 1759, first published 1627).

Fortescue, Sir John, In Praise of the laws of England (De Laudibus Legum Anglia) ed. S.B. Chrimes (Cambridge University Press, Cambridge, 1942).

Fortescue, Sir John, The Governance of England notes by Charles Plummer (reprint Hyperion Press, Westport, Connecticut, 1979, reprint of 1926 edition).

Giles of Rome, De regimine principum (Rome, 1556).

Glanvill, de, Ranulf, Treatise on the Law and Custom of the Realm of England ed. \& trans. G.D. Hall (Clarendon Press, Oxford, 1993, first published 1187-1189).

Godfrey of Fontaines, Quodlibets ed. J. Hoffmans (Université de Louvain, Louvain, 1932), Vol. XI.

Gratian of Bologna, Concordia discordantium canonum (or Decretum magistri Gratiani) in Corpus Iuris Canonici ed. A. Friedberg (Tauchnitz, 1879), Vol. I.

Grotius, Hugo, De jure belli ac pacis libri tres ed. James Scott; trans. Francis Kelsey (Clarendon Press, Oxford, 1925).

Harbin, George, Hereditary Right to the Crown of England Asserted (London, 1713).

Harington, Sir John, A Tract on the Succession to the Crown (AD 1602) ed. R. Clements Markham (London, 1880).

Hobbes, Thomas, Leviathan (Collier, New York, 1962).

James I, H.M. King, Basilikon Doron (Scolar Press, Menston, 1969).

James I, H.M. King, The political works of James I ed. Charles Howard McIlwain (Harvard University Press, Cambridge, 1918).

Eikon Basilike (The Portraiture of His Sacred Majesty in His Solitudes and Sufferings) ed. Phillip Knachel (Cornell University Press, Ithaca, New York, 1966).

John of Paris, De potestate regia et papali, Johannes Quidort von Paris Über Königliche under päpstliche Gewalt ed. F. Bleienstein (Klett, 1969). 
Johnson, Samuel, Of magistracy (L.C., London, 1689).

Kenyon, J. P., The Stuart Constitution: Documents and Commentary (Cambridge University Press, Cambridge, 1966).

Knox, John, First Blast of the Trumpet in The Works of John Knox ed. David Laing (Edinburgh, 1846-1864) 6 vols.

Le Bras, Gabriel, Charles Lefebvre \& Jacqueline Rambaud, L'âge classique, 1140-1378: sources et théorie du droit (Sirey, Paris, 1965).

Locke, John, Two Treatises of Government ed. Peter Laslett (Cambridge University Press, Cambridge, 1988).

Machiavelli, Niccolo, The Prince eds. Quentin Skinner \& Russell Price (Cambridge University Press, Cambridge, 1988).

Mackintosh, Sir James, writing in the Edinburgh Review, Vol. xxxi, pp. 174-180 (1818) in H.J. Hanham, The Nineteenth Century Constitution, 1815-1914 (Cambridge University Press, Cambridge, 1969), 6-10.

Macmillan, Harold, Riding the Storm 1956-1959 (Macmillan, London, 1971).

May, Thomas Erskine, The constitutional history of England since the accession of George the Third, 1760-1860 (Crosby \& Nichols, Boston, Mass., 1862), Vol. 1.

Mill, J.S., Utilitarianism, On Liberty and Considerations on Representative Government ed. H.B. Acton (Dent, London, 1972).

Molyneux, William, The Case of Ireland's being Bound by Acts of Parliament in England ed. J. Barry \& Serjeant G. Hall (Owen Roc O’Nial, Dublin, 1782, first published 1698).

Montesquieu, Charles Louisde Secondat Baron de, "The Spirit of the Laws", in Parliamentary versus Presidential Government ed. Arend Lijphart (Oxford University Press, Oxford, 1992), 48-51.

Oresme, Nicole, Le livres de Politiques d' Aristotle ed. A.D. Menut (1970) Transactions of the American Philosophical Society 137.

Pecock, Reginald, The Donet ed. E.V. Hitchcock (Early English Text Society, London, 1971 reprint of 1921 edition).

Raleigh, Sir Walter, The prerogative of Parliaments in England ... proued in a dialogue (pro o contra) betweene a councellour of state and a iustice of peace. / Written by the worth (much lacked and lamented) Sir Walter Raleigh knight, deceased.; Dedicated to the Kings Maiestie, and to the House of Parliament now assembled (T. Cotes, London, 1640, reprint of 1628 edition).

Rouseau, Jean-Jacques, The Social Contract and other later political writings ed. \& trans. Victor Goureatres (Cambridge University Press, Cambridge, 1997).

Sadler, John, Rights of the kingdom: or, customs of our ancestors. Touching the duty, power, election, or succession of our Kings and Parliaments, our true liberty, due allegiance, three estates, their legislative power, original, judicial, and executive; with the militia. Freely discussed through the British, Saxon, Norman laws and histories. With an occasional discourse of great changes yet expected in the world (J. Kidgell, London, 1682).

Some Considerations Touching Succession And Allegiance (London, 1689).

The Reports of Sir John Spelman (1978), Vol. II, Seldon Society, Vol. 94.

Stanford, Sir William, An exposition of the Kinges prerogatiue: collected out of the great Abridgement of Iustice Fitzherbert, and other olde writers of the lawes of England / by the right worshipfull Sir William Staunford Knight, lately one of the iustices of the Queenes Maiesties Court of common pleas Where vnto is annexed the proces to the same prorogatiue appertaining (Richard Tottel, London, 1577).

Terra Rubea, de, Johannes, Contra rebelles suorum regum ed. J. Bonnand (Paris, 1526).

Viner, Charles, A General Abridgment of Law and Equity (Aldershot, 1742-1753). 
W.G., Case of Succession to the Crown of England Stated (1679).

Wentworth, Peter, A Pithie Exhortation to Her Majestie for Establishing Her Successor to the Crowne. Whereunto is Added a Discourse Containing the Authors Opinion of the True and Lawfull Successor to her Majestie (1598).

Whitelock, Sir James, A learned and necessary argument to prove that each subject hath a propriety in his goods: shewing also the extent of the Kings prerogative in impositions upon the goods of merchants exported and imported, out of and into this kingdome. Together with a remonstrance presented to the Kings most excellent Majesty, by the honourable House of Commons, in the Parliament holden anno. Dom. 1610. annoq[ue] regis Jacobi, 7 / by a late learned judge of this kingdome (John Burroughs, London, 1641).

Wulfstan of York, An Werk Erzbischof Wulfstans von York - Die "Institutes of Polity, Civil and Ecclesiastical” ed. K. Jost (A. Francke, 1959).

\subsection{Printed collections}

A General Collection of Treaty's (London, 1710-1732).

Adams, G.B. \& H.M. Stevens (eds.), Select Documents in English Constitutional History (Macmillan, New York, 1901).

Almon, J., A Collection of all the Treaties of Peace, etc (privately printed, London, 1772).

Bagehot, Walter, "The English Constitution" in The Collected Works of Walter Bagehot, ed. Norman St. John-Stevas (The Economist, London, 1974, first published 1867), Vol. 5.

Bagehot, Walter, The English Constitution (Cambridge University Press, Cambridge, 2001).

Costin, W.C. \& Steven Watson, J., The Law and Working of the Constitution: Documents 1660-1914: Vol. I 1660-1783 (A. \& C. Black, London, 1952), Vol. 1.

Dumont, J., Corps universal diplomatique de droi des gens (Amsterdam, 1726-1732).

English and Empire Digest with complete annotations (Butterworth \& Co., London, 1971), replacement Vol. 11, 1975 reissue, pp. 656-662.

English Historical Documents c.500-1042 ed. D. Whitelock (2nd edn., E. Methuen, London, 1979).

English Historical Documents 1042-1189 eds. D.C. Douglas \& G.W. Greenaway (2nd edn., E. Methuen, London, 1981, first published 1953).

English Historical Documents Vol. iii 1189-1327 ed. Harry Rothwell (Eyre \& Spottiswoode, London, 1975).

English Historical Documents Vol. iv 1327-1485 ed. A.R. Myers (Eyre \& Spottiswoode, London, 1969).

English Historical Documents, 1660-1714, ed. A. Browning (Eyre \& Spottiswoode, London, 1953).

English Historical Documents, 1783-1832 eds. A. Aspinall \& E.A. Smith (Eyre \& Spottiswoode, London, 1959).

English Historical Documents, 1833-1874 eds. G.M. Young \& W.D. Handcock (Eyre \& Spottiswoode, London, 1956).

English Historical Documents, 1874-1914 ed. W.D. Handcock (Eyre \& Spottiswoode, London, 1973).

Halsbury's Laws of England ed. Viscount Hailsham (2nd edn., 1932), Vol. 6.

Halsbury's Laws of England eds. F.H. Lawson \& H.J. Davies (4th edn., 1974), Vol. 8. 
Halsbury's Laws of England ed.-in-ch. LordHailshamof St. Marylebone (4th edn., Butterworths, London, 1974-, first published 1907-1917).

Halsbury's Statutes of England and Wales (3rd edn., Butterworths, London, 1968-1972 \& subsequent reissues).

Hanham, H.J., The Nineteenth Century Constitution, 1815-1914 (Cambridge University Press, Cambridge, 1969).

Hoorn, J. \& D. Goodman (eds.), Vox Reeeipublicae (1996), special edition of Journal of Australian Studies no. 47.

Hudson, Manley Ottmer (ed.), International Legislation: A Collection of the texts of multipartite international instruments of general interest beginning with the Covenant of the League of Nations (Carnegie Endowment for International Peace, Washington, 1931-1950), Vol. 6.

James, Colin (ed.), Building the Constitution (Victoria University of Wellington Institute of Policy Studies, Wellington, 2000).

Jenkinson, C., A Collection of all the Treaties of Peace (London, 1785).

Keith, A.B., Speeches and Documents on the British Dominions, 1918-1931 (Oxford University Press, London, 1932).

Léger, Gules, Governor General of Canada, 1974-1979: A selection of his writings on Canada (Les Éditions la Presse, Montreal, 1982).

McIntyre, W.D. \& W.J. Gardner (eds.), Speeches and Documents on New Zealand History (Clarendon Press, Oxford, 1971).

McNab, Robert, Historical Records of New Zealand (Government Printer, Wellington, 1908).

Plato, Laws and Statesman in The Collected Dialogues of Plato eds. Edith Hamilton \& Huntingdon Cairns (Pantheon, New York, 1961).

Pope, Sir Joseph, Correspondence of John A Macdonald: Selections from the Correspondence of the Rt. Hon. Sir John Alexander Macdonald, G.C.B. (Oxford University Press, Toronto, 1921).

Skelton, O.D., Life and Letters of Sir Wilfrid Laurier (McClelland \& Stewart, Toronto, 1965).

\subsection{Pamphlets}

Benwell, Philip, The Monarchist League and The Role of the Monarch in modern society (The Monarchist League in Australia, Sydney, 1995).

Brookfield, F.M., The Constitution in 1985: The Search for Legitimacy (University of Auckland, Auckland, 1985).

Evans, Harold, The case for a change: in which the author argues that the public interest requires a democratically selected Governor-General or Head of State, and that the people can and should now insist upon it. With an open letter to all Members of the House of Representatives (privately published, Christchurch, 1979).

Finnis, John, Common Law Constraints: Whose Common Good Counts? (University of Oxford Law Faculty Legal Studies Research Paper Series, Working Paper No. 10/2008, March 2008).

Graham, Sir Douglas, Trick or Treaty? (Institute of Policy Studies, Victoria University of Wellington, Wellington, 1997).

Ministry of Foreign Affairs and Trade, Presentation of Credentials in New Zealand (Ministry of Foreign Affairs and Trade, Wellington, 1997).

Tizard, Hon. Dame Catherine, Crown and Anchor; the present role of the Governor-General in New Zealand (Government House, Wellington, 1993). 
Tizard, Hon. Dame Catherine, Colonial Chiefs, 1840-1889: Gipps, Hobson, Fitzroy, Grey, Browne, Grey again, Bowen, Fergusson, Normanby, Robinson, Gordon and Jervois (Wellington Historical and Early Settlers' Association, Wellington, 1995).

The Role of the Governor-General of New Zealand (Government House, Wellington, 1997). Winiata, Whatarangi, "Revolution by Lawful Means" 1993 New Zealand Law Conference Papers, The Law and Politics, Vol. ii.

\subsection{Theses}

Aitken, Judith, "Control of Executive Powers in New Zealand" (1977) Victoria University of Wellington M.P.P. research paper.

Al Namlah, Saleh, "Political legitimacy in Libya since 1969: A Weberian perspective" (1992) Syracuse University Ph.D. thesis.

Attrill, Wayne, "Aspects of the Treaty of Waitangi in the Law and Constitution of New Zealand" (1989) Harvard University LL.M. thesis.

Bedggood, David, "Locked into Legitimacy: A Study of the Place of Values in Politics and Society" (1974) University of Waikato D.Phil. thesis.

Borrows, John Joseph, "A Genealogy of Law: Inherent Sovereignty and First Nations Self-Government" (1991) University of Toronto LL.M. thesis.

Brookfield, F.M., "Some aspects of the Necessity Principle in Constitutional Law" (1972) University of Oxford D.Phil. thesis.

Carter, B.P.C., "The Powers of the Australian and New Zealand Governors-General" (1977) University of Auckland LL.B. (Hons) dissertation.

Cheyne, S.L., "Search for a constitution; People and Politics in New Zealand's Crown Colony Years" (1975) University of Otago Ph.D. thesis.

Clarke, Gregory, "Popular Sovereignty and Constitutional Reform in Canada" (1997) Acadia University M.A. thesis.

Cochran, Timothy, "Competing visions of the Canadian Constitution: Societal Versus Elite Reform between 1982 and 1992" (1995) University of New Brunswick M.A. thesis.

Cox, Noel, "An exploration of the basis of legal authority of the Anglican Church in New Zealand" (2005) Archbishop of Canterbury's Examination in Theology M.A. thesis.

Cox, Noel, "The Evolution of the New Zealand Monarchy: The Recognition of an Autochthonous Polity" (2001) University of Auckland Ph.D. thesis.

Cox, Noel, "The meaning of catholicity with respect to ordained ministry in the Anglican Communion: An examination of the ecclesiology implicit in the validity of orders debate" (2008) University of Auckland M.Theol. thesis.

Dahbour, Omar Hussein, “A critique of national self-determination” (1995) City University of New York Ph.D. thesis.

Hayback, Michael, "Carl Schmitt and Hans Kelsen in the crisis of Democracy between World Wars I and II: A theoretical and historical analysis" (1990) Universitaet Salzburg Dr. Iur. thesis.

Hayward, Janine, "In search of a treaty partner: who, or what, is 'the Crown?" (1995) Victoria University of Wellington Ph.D. thesis.

Hill, Larry Byron, "The International Transfer of Political Institutions: A Behavioural analysis of the New Zealand Ombudsman" (1970) Tulane University Ph.D. thesis.

Jackson, Laura, "Shadows of the Crown: Constructing executive authority in the 'modern' state" (1994) University of Chicago Ph.D. thesis. 
Khumalo, Bekithemba Ralph, "Legal Pluralism and constitutional tensions: the evolution of the constitutional system in Swaziland since 1968" (1993) York University LL.M. thesis.

Kuhn, William, "Ceremony and Politics: The management of British Royal Ceremonial, 1861-1911" (1990) Johns Hopkins University Ph.D. thesis.

Leiren, Terje, "National Monarchy and Norway, 1898-1905 - A study of the establishment of the modern Norwegian monarchy" (1978) University of North Texas Ph.D. thesis.

Liddle, William, “A patriot king, or none: American public attitudes towards George III and the British monarchy, 1754-1776" (1970) Claremont Graduate University Ph.D. thesis.

Lipa, J.S., "The role of the Governor-General in the Commonwealth: A comparative study" (1993) University of Auckland M.Jur. thesis.

MacDonald, Nancy, “Constitutional Symbolism: The Canada Clause" (1992) Queen's University at Kingston M.A. thesis.

McHugh, Paul, "Aboriginal Rights of the New Zealand Maori at common law" (1987) University of Cambridge Ph.D. thesis.

McKenna, Mark, "Republicanism in Australia, 1788-1880" (1996) University of New South Wales Ph.D. thesis.

Messamore, Barbara, "The Governors-General of Canada, 1888-1911: British Imperialists and Canadian Nationalists" (1991) Simon Fraser University M.A. thesis.

Northey, J.F., "The Office of Governor-General - An Appreciation of the significance of that Office in New Zealand" (1950) University of Toronto D.Jur. thesis.

Perry, Barbara, "Canada's Passive Revolution: The Charter of Rights and Hegemonic Politics in Canada" (1992) Carleton University Ph.D. thesis.

Philogene, Simone, "The Feminization of the Crown: The Role of a Governor-General's Consort in Post-Confederation Canada, 1867-1898" (1993) McGill University M.A. thesis.

Pollock, Carolee Ruth, "His Majesty's Subjects: Political legitimacy in Quebec, 1764-1791" (1996) University of Alberta Ph.D. thesis.

Reynolds, Christopher, "Semi-Sovereign Australia" (1984) Claremont Graduate University Ph.D. thesis.

Roth, Brad R., "Governmental illegitimacy in international law: An emerging norm in theoretical perspectives" (1996) University of California, Berkeley Ph.D. thesis.

Ruoff, Kenneth, "The Symbol of Monarchy in Japan's Postwar Democracy, 1945-1995" (1997) Columbia University Ph.D. thesis.

Shannon, Philip, "Becoming a republic: Law reform options for New Zealand" (1995) Victoria University of Wellington LL.M. research paper.

Shearman, Deirdre, "The Image of Victoria: Patronage, Profits and Patriotism" (1996) Brandeis University Ph.D. thesis.

Stevens, Donald, "The Crown the Governor-General and the Constitution" (1974) Victoria University of Wellington LL.M. thesis.

Stone, Richard, "Self-Determination: 'Political Principle' to legal 'right" (1997) Victoria University of Wellington LL.M. research paper.

Swanson, Matthew Lane, "The social extract tradition and the question of political legitimacy" (1995) University of Missouri-Columbia Ph.D. thesis.

Truax, Jean Ann, "The making of the King 1135: Gender, family and custom in the Anglo-Norman succession crisis" (1995) University of Houston Ph.D. thesis.

Van Halst, Walter, "Democracy, Meech Lake and Constitutional Reform" (1991) University of Calgary M.A. thesis. 
Williams, David, "The Use of Law in the Process of Colonialization; An Historical and Comparative Study with Particular Reference to Tanzania (mainland) and New Zealand" (1985) University of Dar es Salaam Ph.D. thesis.

Williams, Richard, "Public Discussion of the British Monarchy, 1837-87' (1989) University of Cambridge Ph.D. thesis.

\subsection{Articles}

Agnew of Lochnaw, Sir Crispin, "The Conflict of heraldic laws" (1988) Juridical Review 61. Allen, Stephen, "International Law and the Resettlement of the (Outer) Chagos Islands" (2008) 8 Human Rights L.R. 683.

Allen, Stephen, "Looking beyond the Bancoult Cases: International Law and the Prospect of Resettling the Chagos Islands" (2007) 78 Human Rights L.R. 441.

Allen, T.R.S., "Legislative supremacy and the rule of law - Democracy and Constitutionalism" (1985) 44 Cambridge L.J. 111.

Anon, “Art. IV: On the Alien Bill” (1825) 42 Edinburgh Review 99-174.

Anon, "Breaking New Ground" (1998) 111(135) Maclean's 18.

Anon, "Documents concerning the constitutional events which surrounded the Tasmanian General Election in 1989" (1991) 2 Public L.R. 4.

Anon, "The Effect of the Treaty of Waitangi on Subsequent Legislation" [1934] 10 New Zealand L.J. 13.

Anson, Sir William, "The Government of Ireland Bill and the Sovereignty of Parliament" (1886) 2 L.Q.R. 427.

Archer, Jeff, "The making of a president: Ireland's model for Australia?" (1998) 74(5) Current Affairs Bulletin 4.

Armstrong, Sir William, "The Role and Character of the Civil Service” (1970) 56 Proceedings of the British Academy 211.

Atkinson, Alan, "The Australian Monarchy: Imperfect But Important" (1993) 28 A.J.P.S. 67.

Bailey, K.H., "The Abdication Legislation in the United Kingdom and the Dominions (pt.1)" (1938) 3 Politica 1.

Bailey, K.H., "The Abdication Legislation in the United Kingdom and the Dominions (pt. 2)" (1938) 3 Politica 147.

Baker, G. Blaine, “The Reconstitution of Upper Canadian Legal Thought in the Late-Victorian Empire" (1985) 3 Law and History Review 219-292.

Baker, Sir John H., "English Law and the Renaissance" (1985) Cambridge L.J. 46.

Balls, H.R., "Governor General's Warrants" (1963) 3 Canadian Tax Journal 181.

Bartlett, Richard, "The fiduciary obligation of the Crown to the Indians" (1989) 53 Saskatchewan L.R. 301.

Bartlett, Richard, “You can't trust the Crown: The fiduciary obligation of the Crown to the Indians" (1989) 53 Saskatchewan L.R. 367.

Beasley, F.R. \& R.W. Baker, "The Need for Co-operation in State and Commonwealth Laws" (1949) 23 A.L.J. 188.

Beckerman, John, "Succession in Normandy 1087 and in England 1066: the role of testamentary custom" (1972) 47 Speculum 258-260.

Bell, D.G., "A Note on the Reception of English Statutes in New Brunswick" (1979) 28 Univ. N.B. L.J. 195.

Blackburn, R.W., “The Queen and Ministerial responsibility” (1985) Public Law 361. 
Bllick, Andrew, "Emergency powers and the withering of the Royal Prerogative" (2014) 18(2) The International Journal of Human Rights 195-210.

Blundell, Sir Denis, "Some Reflections Upon the Office of Governor-General in New Zealand" (1980) 10 V.U.W.L.R. 198.

Bogdanor, Vernon, “Mirror for a multicultural age?” Times Literary Supplement, 31st July 1998, p. 13.

Bogdanor, Vernon, “The Monarchy and the Constitution" (1996) 49 Parliamentary Affairs 407.

Boivin, Richard, "The Coté Decision: Laying to Rest the Royal Proclamation" [1995] 1 C.N.L.R. 1-22.

Boston, Jonathan, Stephen Levine, Elizabeth McLeay \& Nigel Roberts, "Experimenting with coalition government: preparing to manage under proportional representation in New Zealand" (1997) 35(3) J.C.C.P. 108.

Boston, Jonathan, Stephen Levine, Elizabeth McLeay, Nigel Roberts \& Hannah Schmidt, "Caretaker governments and the evolution of caretaker conventions in New Zealand" (1998) 28(4) V.U.W.L.R. 629.

Boyd, Andrew, "Catholicism and republicanism in Ireland" (1995) 266 Contemporary Review 57.

Bradley, A.W., "Police Powers and the Prerogative" [1988] Public Law 298-303.

Brookfield, F.M., "A New Zealand Republic?” (1994) 8 Legislative Studies 5.

Brookfield, F.M., "Convention, Cabinet and executive council: Skyring's case" (1986) 12(2) N.Z.U.L.R. 204.

Brookfield, F.M., "Kelsen, the Constitution and the Treaty" (1992) 15 N.Z.U.L.R. 163.

Brookfield, F.M., "New Zealand and the United Kingdom: One Crown or Two?" [1976] New Zealand L.J. 458.

Brookfield, F.M., "No Nodding Automaton: A Study of the Governor-General's Powers and Functions" [1978] New Zealand L.J. 491.

Brookfield, F.M., "Parliamentary Supremacy and Constitutional Entrenchment: A Jurisprudential Approach" (1984) 5 Otago L.R. 603.

Brookfield, F.M., "Republican New Zealand: legal aspects and consequences" (1995) 3 N.Z.L.R. 310.

Brookfield, F.M., "The Courts, Kelsen, and the Rhodesian Revolution" (1969) 19 U.T.L.J. 326-352.

Brookfield, F.M., "The Fiji revolution of 1987" [1988] New Zealand L.J. 250-256.

Brookfield, F.M., "The Monarchy and the Constitution today: a New Zealand perspective" [1992] New Zealand L.J. 438.

Brookfield, F.M., "The reconstituted office of Governor-General" [1985] New Zealand L.J. 256.

Burrows, Andrew, "We Do This At Common Law But That in Equity" (2002) 22(1) Oxford Journal of Legal Studies 1-16.

Carter, B., "The Incorporation of the Treaty of Waitangi into Municipal Law" (1980) 4 A.U.L.R. 1.

Chapman, Guy, "The Treaty of Waitangi - Fertile Ground for Judicial (and Academic) Myth-making" [1991] New Zealand L.J. 228.

Chen, Mai, "Remedying New Zealand's Constitution in crisis: Is M.M.P. part of the Answer?" [1993] New Zealand L.J. 22-39.

Cheyett, F.L., "Custom, case-law and medixval 'constitutionalism" (1963) 78 Political Science Quarterly 362. 
Cheyney, Edward P., "The Court of Star Chamber" (1913) 18(4) The American Historical Review 727-750.

Cobham, Viscount, "The Governor-General's Constitutional Role" (1963) 15(2) Political Science 4.

Cohen, David, "Thinking about the State: law reform and the Crown in Canada" (1986) 24 Osgoode Hall L.J. 379.

Colley, Linda, "The Apotheosis of George III" (1984) 102 Past and Present 94.

Collinson, Patrick, "Monarchical Republic of Queen Elizabeth I" (1987) 69 Bulletin of the John Rylands University Library of Manchester 394-424.

Conley, Richard, "Sovereignty or the Status Quo? The 1998 pre-referendum debate in Quebec" (1997) 35(1) J.C.C.P. 67.

Cooke, Don, "First Letter to the Republicans" (1999) Arena 15.

Cooke of Thorndon, Lord, "Fundamentals" [1988] New Zealand L.J. 158.

Corbett, Sir William, "The Crown as Representing the State" (1903) l Commonwealth L.R. 23.

Costello, Kevin, “The Expulsion of Prerogative Doctrine from Irish Law: Quantifying and Remedying the Loss of the Royal Prerogatives" (1997) 32 Irish Jurist 145-194.

Coté, J.E., "The Reception of English Law" (1977) 15 Alta. L. Rev. 29.

Cowen, Sir Zelman, "The Office of Governor-General” (1985) 114 Daedalus 127.

Cowen, Sir Zelman, "Understanding the office of Governor-General of Australia" (1994) 108 Australian Defence Force Journal 47.

Cox, Noel, "A New Supreme Court of New Zealand" (2003) 12(3) The Commonwealth Lawyer 25-28.

Cox, Noel, "Black v. Chrétien: Suing a Minister of the Crown for Abuse of Power, Misfeasance in Public Office and Negligence" (September 2002) 9(3) E-Law, Murdoch University Electronic Journal of Law available at <http://www.murdoch.edu.au/elaw/ issues/v9n3/cox93.html>.

Cox, Noel, "Commonwealth Heraldic Jurisdiction: with specific emphasis on the Law of Arms in New Zealand" (2005) 1(210) The Coat of Arms (3rd series) 145-162.

Cox, Noel, "Proposed constitutional reform in New Zealand: Constitutional entrenchment, written constitutions, and legitimacy" (2013) 102(1) The Round Table, the Commonwealth Journal on International Affairs 51-70.

Cox, Noel, "Republican Sentiment in the Realms of the Queen: The New Zealand Perspective" (2001-2002) 29(1) Manitoba L.J. 1-28.

Cox, Noel, "Royal Yachts in New Zealand" (1997) 11(2) The Raggie, the Newsletter of the Royal New Zealand Navy Museum 6.

Cox, Noel, "The abolition or retention of the Privy Council as the final Court of Appeal for New Zealand: Conflict between national identity and legal pragmatism" (2002) 20(2) New Zealand Universities L. Rev. 220-238.

Cox, Noel, "The British Peerage: The Legal Standing of the Peerage and Baronetage in the Overseas Realms of the Crown with Particular Reference to New Zealand" (1997) 17 (4) New Zealand Universities L. Rev. 379-401.

Cox, Noel, "The control of advice to the Crown and the development of executive independence in New Zealand" (2001) 13(1) Bond L. Rev. 166-189.

Cox, Noel, "The Coronation Robes of the Sovereign" (1999) 5(1) Arma, the Journal of the Heraldry Society of Southern Africa 271-280.

Cox, Noel, "The Dichotomy of Legal Theory and Political Reality: The Honours Prerogative and Imperial Unity" (1998-1999) 14 Australian Journal of Law and Society 15-42. 
Cox, Noel, "The effect of the advent of the Mixed-Member Proportional voting system upon the role of the Governor-General of New Zealand" (2002) 14(2) Bond L. Rev. $424-441$.

Cox, Noel, "The Evolution of the Office of Governor-General of New Zealand" (2001) 5(1\&2) Mountbatten Journal of Legal Studies 51-77.

Cox, Noel, "The Influence of the Common Law and the Decline of the Ecclesiastical Courts of the Church of England" (2002-2003) 3(1) Rutgers Journal of Law and Religion available at <https://lawandreligion.com/sites/law-religion/files/The-In fluence-Cox.pdf> Retrieved 24 April 2020.

Cox, Noel, "The Law of Arms in New Zealand" (1998) 18(2) N.Z.U.L.R. 225-256.

Cox, Noel, "The law of succession - a lesson in how not to reform transnational law" (October 2013) 102(5) The Round Table, the Commonwealth Journal on International Affairs 477-480.

Cox, Noel, "The Law of Succession to the Crown in New Zealand" (1999) 7 Waik. L.R. $49-72$.

Cox, Noel, "The Revenge of the Arcane Exclusion Clause: The Civil Registration of Marriage and the Royal Family" (2005) 5(2) Oxford University Commonwealth L.J. 179-204.

Cox, Noel, "The Review of the New Zealand Royal Honours System" (1997) 75 New Zealand Numismatic Journal, Proceedings of the Royal Numismatic Society of New Zealand 17-21.

Cox, Noel, "The royal prerogative in the realms" (2007) 33(4) Commonwealth Law Bulletin 623-649.

Cox, Noel, "The Theory of Sovereignty and the Importance of the Crown in the Realms of The Queen" (2002) 2(2) Oxford University Commonwealth L.J. 237-255.

Cox, Noel, "The Treaty of Waitangi and the Relationship between Crown and Maori in New Zealand" (2002) 28(1) Brooklyn Journal of International Law 123-153.

Dawson, Hon. Sir Daryl, "The Constitution - Major Overhaul or Simple Tune-up?" (1984) 14 Melbourne University L.R. 353.

Dawson, R. MacGregor, "The Royal Power of Dissolution of Parliament in the British Commonwealth by Eugene Forsey" (book review) (1944) 10 C.J.E.P.S. 88.

de Smith, S.A., "The Royal Style and Titles" (1953) 2 I.C.Q. 263.

de Smith, S.A., "The Separation of Powers in New Dress" (1966) 12 McGill L.J. 491.

Dearlove, J., "Bringing the State Back In" (1989) Political Studies 521.

Delany, V.T.H., "Illegal Conditions Precedent and Legacies of Personalty" (1955) 19 Conv. 176.

Delany, V.T.H., "The Constitution of Ireland: Its Origin and Development" (1957-1958) 12 Univ. Toronto L.J. 1.

Dias, R.W.M., "Legal Politics: Norms behind the Grundnorm" (1968) 26(2) Cambridge Law Journal 233.

Dickinson, H.T., "The Eighteenth-Century Debate on the 'Glorious Revolution"” (1976) 61 History 28-45.

Dickinson, H.T., "The Eighteenth-Century Debate on the Sovereignty of Parliament" (1976) 26 Transactions of the Royal Historical Society (5th Series) 189-210.

Dixon, Dennis, “Godden v. Hales revisited - James II and the dispensing power” (2006) 27(2) The Journal of Legal History 129-152.

Dixon, Sir Owen, "The Law and the Constitution" (1935) 51 L.Q.R. 590.

Doe, Norman, "Non-Legal rules and the courts: enforceability" (1987) 9 Liverpool L.R. 173.

Douglas, David, "Edward the Confessor, Duke William of Normandy and the English Succession" (1953) 68 English Historical Review 526-545. 
Downey, Patrick, "A constitutional monarchy" [1986] New Zealand L.J. 1.

Downey, Patrick, "Monarchy to Republic" (book review) [1988] New Zealand L.J. 10.

Downey, Patrick, "Royal Prerogative, ministers and Parliament" [1995] New Zealand L.J. 173.

Downey, Patrick, "Sovereignty, the Common Law, and the Treaty of Rome" [1992] New Zealand L.J. 185.

Downey, Patrick, "The monarchy, the Judges and the Constitution" [1994] New Zealand L.J. 161.

Doyle, Timothy, "The Conservative mythology of monarchy: Impacts Upon Australian Republicanism" (1993) 28 A.J.P.S. 121.

Dunham, W.H. \& Wood, C.T., "Right to Rule in England: Deposition and the Kingdom's Authority, 1327-1485" (1976) 81 American Historical Review 738-761.

Dunn, John, "Consent in the Political Theory of John Locke" (1967) 10 Historical Journal 3.

Edeson, W.R., "The Prerogative of the Crown to Delimit Britain's Maritime Boundary" (1973) 89 L.Q.R. 364.

Elliott, Mark \& Amanda Perreau-Saussine, "Pyrrhic Public Law: Bancoult and the Sources, Status and Content of Common Law Limitations on Prerogative Powers" (2009) 72 Modern L.R. 697.

Esman, Milton, "Ethnic Pluralism and International Relations" (1990) 17(1-2) Canadian Review of Studies in Nationalism 83.

Estep, David, "Losing jewels from the Crown: considering the future of the monarchy in Australia and Canada" (1993) 7 Temple International \& Comparative L.J. 217.

Farran, d'Olivier C., "The Law of the Accession" (1953) 16 M.L.R. 140.

Fogarty, John, "Philip Joseph, Constitutional and Administrative Law in New Zealand (The Law Book Co., Sydney, 1993)" (book review) [1993] New Zealand L.J. 212.

Forsey, Eugene, "The Role and Position of the Monarch in Canada" (1983) 64 Parliamentarian 6.

Forsey, Eugene, “The Role of the Crown in Canada since Confederation" (1979) 60 Parliamentarian 14.

Frug, G.E., "The Ideology of Bureaucracy in American Law" (1984) 97 Harv. L. Rev. 1193.

Galligan, Brian, "Regularising the Australian Republic" (1993) 28 A.J.P.S. 56.

Goldwin, R.A., "Locke's state of nature in political society" (1976) 31 Western Political Quarterly 126-135.

Gordon, Michael, “The Conceptual Foundations of Parliamentary Sovereignty: Reconsidering Jennings and Wade" (2009) Public Law 519-543.

Gray, H.R., "The Sovereignty of Parliament Today" (1953-1954) 10 Univ. Toronto L.J. 54.

Gregory, Gordon, "Police power and the role of the provincial Minister of Justice" (1979) 27(1) Chitty's L.J. 14.

Gutoff, Jonathan, "Like a Sturgeon?: Royal Fish, Royal Prerogative and Modern Executive Power" (2007) Roger Williams University School of Law Faculty Papers.

Haast, Ernest, "Nationalism: An instrumental social construction" (1993) 22(3) Millennium Journal of International Studies 505.

Hancock, I.R., "The 1911 Imperial Conference" (1966) 12 Historical Studies 306.

Harcourt, Freda, "Gladstone, monarchism and the 'New Imperialism" (1985) 14(1) Journal of Imperial and Commonwealth History 28.

Hardie Boys, Sir Michael, "Continuity and Change: the 1996 General Election and the Role of the Governor-General" (1997) 5 Waik. L.R. 1.

Hardie Boys, Sir Michael, “The Role of the Governor-General under M.M.P.” (1996) 21(4) N.Z. International Review 2.

Harlow, Carol, “The Crown: Wrong once again?” (1977) 40 M.L.R. 728. 
Harris, Bruce, "The Constitutional Future of New Zealand" (2004) N.Z.L.R. 269.

Harris, Bruce, "The Law-making powers of the New Zealand General Assembly: Time to Think about change" (1984) 5 Otago L.R. 565.

Harris, Bruce, "The 'Third Source' of Authority for Government Action" (1992) 109 L.Q.R. 626.

Harris, Bruce, “The 'Third Source' of Authority for Government Action Revisited" (2007) 123 L.Q.R. 225-250.

Harris, M.C. \& J.R. Crawford, "The Powers and Authorities Vested in Him" (1969) 3 Adelaide L.R. 303.

Harrison Moore, Sir William, "Law and Government" (1905) 3 Commonwealth L.R. 205.

Harrison Moore, Sir William, "Liability for the Acts of Public Servants" (1907) 23 L.Q.R. 112.

Hicks, Bruce M., "British and Canadian Experience with the royal prerogative" (Summer 2010) Canadian Parliamentary Review 18-24.

Hirst, John, "The Conservative Case for an Australian Republic" (1991) 35(280) Quadrant 9-13.

Hodson, H., "Crown and Commonwealth" (1995) 333 Round Table 89.

Honoré, Antony, "Allegiance and the Usurper" [1967] Cambridge L.J. 214.

Honoré, Antony, "The right to rebel" (1988) 8 Oxford J.L.S. 34.

Holdsworth, Sir William, "The Prerogative in the Sixteenth Century" (1921) 21(6) Columbia L.R. 554-571.

Hooper, Wilfrid, “The Court of Faculties” (1910) 25 English Historical Review 670.

Howe, Paul, "Nationality and Sovereignty Support in Quebec" (1998) 31(1) C.J.P.S. 31.

Hughes, Camilla, "The fiduciary obligations of the Crown to aborigines: lessons from the U.S. and Canada" (1993) 16 University N.S.W. L.J. 70.

Huscroft, Grant, "Politics and Principle in Public Law Advocacy - the Role of the Solicitor-General" (1999) 18 N.Z.U.L.R. 584.

Illingworth, G.M., "Revolution and the Crown" [1987] New Zealand L.J. 207.

Jamieson, Nigel, "The demise of the Crown" [1989] New Zealand L.J. 329.

Jamieson, Nigel, "Windsor and Watergate" [1993] New Zealand L.J. 74.

Jenks, Edward, "The Imperial Conference and the Constitution" (1927) 3 Cambridge L.J. 13.

Johnston, Darlene, “A theory of Crown trust towards aboriginal peoples" (1986) 18 Ottawa L. Rev. 307.

Joseph, Philip, "Foundations of the Constitution" (1989) 4 Cantaur L. Rev. 58.

Joseph, Philip, "Suspending Statutes Without Parliament's Consent” (1991) 14 N.Z.U.L.R. 282.

Joseph, Philip, "The Crown as a legal concept (I)" [1993] New Zealand L.J. 126.

Joseph, Philip, "The Crown as a legal concept (II)" [1993] New Zealand L.J. 179.

Kay, R.S., "The Creation of Constitutions in Canada and the United States" (1984) 7 Canada-US L.J. 111.

Keith, Sir Kenneth, "The Treaty of Waitangi in the Courts" (1990) 14 N.Z.U.L.R. 37.

Kennedy, W.P.M., "Evatt, The King and his Dominion Governors" (book review) (1938) Univ. Toronto L.J. 408.

Kennedy, W.P.M., “The Regency Acts 1937-53” (1953-1954) 10 Univ. Toronto L.J. 248.

Kennedy, W.P.M., "The Royal Style and Titles" (1953-1954) 10 Univ. Toronto L.J. 83.

Kesselring, K.J., "Felony forfeiture in England, c1170-1870" (2009) 30 The Journal of Legal History 201-226.

Kirby, Hon. Mr Justice Michael, "The Australian Constitutional Monarchy and its likely survival" [1993] New Zealand L.J. 201. 
Kirk-Greene, Anthony, “The Governors-General of Canada, 1867-1952" (1977) 12 Journal of Canadian Studies 35.

Komesar, Neil, "Taking Institutions seriously: Introduction to a strategy for constitutional analysis" (1984) 51 U. Chi. L. Rev. 366.

Krasner, S., "Sovereignty: an institutional perspective" (1988) 21(1) Comparative Political Studies 66.

Langer, Albert, "Confound their politics" (1998) 42(5) Quadrant 10.

Laski, Harold, "The Responsibility of the State in England" (1919) 32 Harv. L.J. 447.

Laski, Harold, "The Theory of Popular Sovereignty" (1919) 17 Mich. L.R. 201-215.

Latham, Richard, "What is an Act of Parliament?" (1939) King's Counsel 152.

Lauterpacht, Sir Eli, “Sovereignty - myth or reality?” (1997) 73(1) International Affairs 137.

Laxon, Bill, "The Notary Public" [1997] New Zealand L.J. 65.

Le Patourel, J.H., “The Norman Succession 996-1135” (1971) 86 English Historical Review 225-250.

Leyser, Karl, "The Anglo-Saxon Succession 1120-1125" (1990) 13 Proceedings of the Battle Conference on Anglo-Norman Studies 225-241.

Loughlin, Martin, “Towards a Republican Revival?” (2006) 26(2) Oxford Journal of Legal Studies $425-437$.

Loveland, Ian, "Parliamentary Sovereignty and the European Community: the Unfinished Revolution?” (1996) 49(4) Parliamentary News 517.

Maclaurin, R.C., "On the nature and evidence of title to realty" (1999) 30(1-2) Victoria University of Wellington L.R. 655-659.

Maitland, Frederic, “The Crown as a Corporation" (1901) 17 L.Q.R. 131.

Mallory, J.R., “An Affair of Discretion” (1985) 92 Q.Q. 758-764.

Mallory, J.R., "The Appointment of the Governor General: Responsible Government, Autonomy, and the Royal Prerogative" (1960) 26 C.J.E.P.S. 96.

Mallory, J.R., "The Office of Governor-General Reconsidered" (1978) 13 Politics 216.

Markesinis, Basil S., "The Royal Prerogative Revisited” (1973) 32 Cambridge L.J. 287.

Marshall, Sir John, "The Power of Dissolution as Defined and Exercised in New Zealand" (1977) 58 Parliamentarian 13.

Massey, Calvin, "The locus of Sovereignty: judicial review, legislative supremacy, and federation in the constitutional tradition of Canada and the USA" [1990] Duke L.J. 1229.

Mathieson, D.L., "Does the Crown have human powers?" (1992) 15 N.Z.U.L.R. 117.

Mayer, Jeremy \& Lee Sigelman, "Zog for Albania, Edward for Estonia, and Monarchs for All the Rest? The Royal Road to Prosperity, Democracy, and World Peace" (1998) 31 (4) P.S.: Political Science and Politics 771.

Mayer, Thomas F., "Sovereignty, sovereignty, who's got the sovereignty" (1994) 25 Sixteenth Century Journal 399.

McGrath, John, "Principles for sharing Law Officer power - the role of the New Zealand Solicitor-General” (1998) 18 N.Z.U.L.R. 197.

McHugh, Paul, "Constitutional Myths and the Treaty of Waitangi" [1991] New Zealand L.J. 316.

Mello, Patrick A., "Curbing the royal prerogative to use military force: the British House of Commons and the conflicts in Libya and Syria" (2017) 40(1) Western European Politics 80-100.

Merelmen, Richard, "Learning and Legitimacy" (1966) 60(3) American Political Science Review 548. 
Mikaere, Annie, "Waitangi: Maori and Pakeha Perspectives of the Treaty of Waitangi" (book review) (1990) 14 N.Z.U.L.R. 97.

Mitchell, J.D.B., “The Flexible Constitution” (1960) Public Law 349.

Molloy, Anthony, "The Non-Treaty of Waitangi" [1971] New Zealand L.J. 193.

Molot, Henry, "Administrative Discretion and Current Judicial Activism" (1979) 11 Ottawa L. Rev. 337-370.

Morris, Caroline, "The Governor-General, the Reserve Powers, Parliament and M.M.P.: A New Era" (1995) 25 V.U.W.L.R. 345.

Morris, J.H.C., "Notes on recent cases 2: Will cases" (1947) 11 Conv. 218.

Morris, Marilyn, "The royal family and family values in late eighteenth-century England" (1996) 21(4) Journal of Family History 519.

Moules, Richard, "Judicial Review of Prerogative Orders in Council: Recognising the Constitutional Reality of Executive Legislation" (2008) Cambridge L.J. 12.

Mulgan, Richard, "Can the Treaty of Waitangi provide a constitutional basis for New Zealand's political future?” (1989) 41(2) Political Science 51.

Munro, Colin, "Laws and conventions distinguished" (1975) 91 L.Q.R. 218.

Nielsen, Claire, "The Executive Treaty-making Prerogative: A History and Critique" (2008) 4 N.Z. Yearbook of International Law 173.

Northey, J.F., "Privy Council Appeals" [1983] New Zealand L.J. 229.

Northey, J.F., "The Governor-General's Powers” (1950) 26 New Zealand L.J. 297.

O'Connell, Daniel, "Canada, Australia, Constitutional Reform and the Crown" (1979) 60 Parliamentarian 5.

O'Connell, Daniel, “The Crown in the British Commonwealth" (1957) 6 I.C.L.Q. 105.

Oakley, Francis, "Jacobean Political Theology: The Absolute and Ordinary Powers of the King" (1968) 29 Journal of the History of Ideas 323.

Oleson, Tryggvi Julius, "Edward the Confessor's Promise of the Throne to Duke William of Normandy" (1957) 72 English Historical Review 221-228.

Palmer, Stephanie, "They Made a Dessert and Called it Peace: Banishment and the Royal Prerogative" (2001) Cambridge L.J. 234.

Philpott, Daniel, "Sovereignty: an introduction and brief history" (1995) 48(2) Journal of International Affairs 353.

Poole, Thomas, "Constitutional Exceptionalism and the Common Law" (2009) 7 International Journal of Constitutional Law 247.

Poole, Thomas, "United Kingdom: The Royal Prerogative" (2010) 8(1) I•CON 146-155.

Postle, H.T., "Commonwealth and Crown" (1929) 3 A.L.J. 109.

Quentin-Baxter, R.Q., "The Governor-General's Constitutional Discretion; An essay towards a re-definition" (1980) 10 V.U.W.L.R. 289.

Radding, C.M., "Evolution of medieval mentalities; a cognitive-structural approach" (1978) lxxxviii American Historical Review 594-597.

Read, J.E., "The Early Canadian Constitutions" (1948) 26 Canadian Bar Review 633.

Reynolds, Susan, "Law and Community in Western Christendom, c.900-1140" (1981) 25 American Journal of Legal History 205.

Richardson, H.G., “The English Coronation Oath" (1949) 24(1) Speculum 44-75.

Robertson, Bernard, "Philip Joseph, Constitutional and Administrative Law in New Zealand" (book review) [1993] New Zealand L.J. 213.

Ross, Angus, "Reluctant Dominion or Dutiful Daughter? New Zealand and the Commonwealth in the Inter-War Years" (1972) 10(1) J.C.P.S. 43.

Russell, Conrad Earl, "In Search of the British Constitution" (1997) 4801 Times Literary Supplement, 7 March 1997, 15. 
Sawyer, Geoffrey, "The Governor-General of the Commonwealth of Australia" (1976) 52 Current Affairs Bulletin 20.

Schaffer, Kay, "Women and the republic: dancing to a different tune?" (1999) 25(1) Hecate 94.

Searles, Janis, "Another Supreme Court move away from recognition of tribal sovereignty" (1995) 25(1) Environmental Law 209.

Seymour, John, "Parens Patriae and Wardship Powers: Their Nature and Origins" (1994) 14(2) Oxford Journal of Legal Studies 159-188.

Sharman, Campbell, "Australia as a Compound Republic" (1990) 25 Politics 1.

Shaw, Lord, "Law as a Link of Empire" (1923) l Canadian Bar Review 19.

Slattery, Brian, "The Independence of Canada" (1983) 5 Supreme Court L. Rev. (Can.) 369.

Smart, P.St.J., "Revolution, Constitution and the Commonwealth: Grenada" (1986) 35 I. C.L.Q. 950.

Smith, David E., "Bagehot, the Crown, and the Canadian Constitution" (1995) 28 C.J.P.S. 619.

Smith, David E., "Empire, Crown and Canadian Federalism" (1991) 24 C.J.P.S. 451.

Spitzer, Matthew, "An Economic Analysis of Sovereign Immunity in Tort" (1977) 50

S. Cal. L. Rev. 515.

Sproule-Jones, Mark, "The Enduring Colony? Political Institutions and Political Science in Canada" (1984) 14 Publius 93.

Stevens, Donald, "Sir Basil? Or Mr Arthur?" [1976] New Zealand L.J. 30.

Stockley, Andrew, "Parliament, Crown and Treaty: inextricably linked?" (1996) 17 N.Z.U. L.R. 193.

Stockley, Andrew, “The Governor-General and M.M.P.” [1996] New Zealand L.J. 213.

Stubbs, Rt. Rev'd. William, "Lambeth Degrees" (May 1864) l Gentleman's Magazine \& Historical Review 633 and 635.

Tarifa, Fatos, "The quest for legitimacy and the withering away of utopia" (1997) 76(2) Social Forces 437.

Taylor, Antony, "Republican ruminations from Down Under" (1995) 45(11) History Today 6.

Thomson, James, "The Australia Acts 1986: A State Constitutional Law Perspective" (1990 Special Issue) 20 Western Australia L.R. 409.

Tierney, Brian, "Some Recent Works on the Political Theories of the Mediæval Canonists" (1954) 10 Traditio 594.

Tom, Fennell, "Royal challenge - voters will decide whether to get rid of the Queen" (1998) 111(8) Maclean's 27.

Tomkins, Adam, "Magna Carta, Crown and Colonies" (2001) Public Law 571.

Toporoski, Richard, "The Invisible Crown Revealed" (1996) 21(3) Monarchy Canada 12.

Twomey, Anne, "Pushing the Boundaries of Executive Power - Pape, the Prerogative and Nationhood Powers" [2010] MelbULawRw 9; (2010) 34(1) Melbourne University L.R. 313.

Uhr, John, “Instituting Republicanism: Parliamentary Vices, Republican Virtues?” (1993 Special Issue) A.J.P.S. 27.

Ullmann, Walter, "This Realm of England is an Empire" (1979) 30(2) Journal of Ecclesiastical History 175.

Wade, Sir William, "Procedure and Prerogatives in Public Law" (1985) 101 L.Q.R. 180.

Wade, Sir William, "The Basis of Legal Sovereignty" (1955) Cambridge L.J. 172.

Wagner, Sir Anthony \& George Squibb, "Precedence and Courtesy Titles" (1973) 80 L.Q.R. 352.

Walker, Clive, "Review of the Prerogative: The Remaining Issues" (1987) Public Law 62. 
Ward, Alan, "Historical Claims under the Treaty of Waitangi: avenue of reconciliation or source of new divisions?” (1993) 28(2) Journal of Pacific History 181.

Ward, Robert, "Baton rounds and circulars" [1988] 47(2) Cambridge. L.J. 155-157.

Warden, James, "The Fettered Republic: The Anglo-American Commonwealth and the Tradition of Australian Political Thought" (1993) 28 A.J.P.S. 83.

Warhurst, John, "Nationalism and Republicanism in Australia: The evolution of Institutions, Citizenship and Symbols" (1993) 28 A.J.P.S. 100.

Washbrook, D.A., "Law, State and Agrarian Society in Colonial India" (1981) 15(3) Modern Asian Studies 649-721.

Waskan, Jonathan, "De facto legitimacy and popular will" (1998) 24(1) Social Theory and Practice 25.

Wheare, Sir Kenneth, "Walter Bagehot" (1974) 60 Proceedings of the British Academy 195. Whyte, John, "The Australian Republican Movement and Its Implications for Canada" (1993) 4 Constitutional Forum 88.

Williams, David, "Chapman is Wrong" [1991] New Zealand L.J. 373.

Williams, David, "The annexation of New Zealand to New South Wales in 1840: What of the Treaty of Waitangi" [1985] Australian Journal of Law and Society 41.

Williams, David, "The Constitutional Status of the Treaty of Waitangi: an historical perspective" (1990) 14(1) N.Z.U.L.R. 9.

Williams, David, "The Foundation of Colonial Rule in New Zealand" (1988) 13(1) N.Z.U. L.R. 54 .

Williams, Ann, "Some Notes and Considerations on problems connected with the English Royal Succession, 860-1066" (1979) 1 Proceedings of the Battle Conference on Anglo-Norman Studies 144-168.

Wilson, Margaret, “The Reconfiguration of New Zealand Constitutional Institutions: The Transformation of Tino Rangatiratanga into Political Reality?” (1997) 5 Waik. L.R. 17.

Winterton, George, "Is the House of Lords Immortal?" (1979) 95 L.Q.R. 386.

Winterton, George, "Modern Republicanism" (1992) 6(2) Legislative Studies 21.

Winterton, George, "Reserve Powers in an Australian Republic" (1993) 2 Univ. Tasmania L. Rev. 249.

Winterton, George, “Tasmania's Hung Parliament 1989” [1992] Public Law 243.

Winterton, George, "The evolution of a separate Australian Crown" (1993) 19 Monash U.L.R. 1.

Wolfers, Edward, "Discretion, Politics and the Governors-General: Some comparisons between Papua New Guinea and Australia" (1977) Australian Quarterly 76.

Wood, Antony, "New Zealand's Patriated Governor-General" (1986) 38(2) Political Science 113.

\section{Secondary and tertiary sources}

Abbott, Tony, How to win the constitutional war and give both sides what they want (A.C.M./Wakefield Press, Adelaide, 1997).

\subsection{Books}

Abbott, Tony, The Minimal Monarchy (A.C.M./Wakefield Press, Adelaide, 1995).

Adams, G.B., The Constitutional History of England (H. Holt, New York, 1922).

Adams, G.B., The Origin of the English Constitution (Yale University Press, New Haven, 1912). 
Adams, Peter, Fatal Necessity (Oxford University Press, Auckland, 1977).

Agaben, Giorgio, State of Exception trans. Kevin Attell (University of Chicago Press, Chicago, 2005).

Allen, Sir Carleton, The Queen's Peace (Stevens \& Sons Ltd, London, 1953).

Allison, Ronald \& Lady SarahRiddell (eds.), The Royal Encyclopaedia (Macmillan Press, London, 1991).

Amery, Leopold, Thoughts on the Constitution (2nd edn., Oxford University Press, London, 1953).

Amleto, Giovanni Cicognani, Joseph Michael O’Hara \& Francis Brennan, Canon Law (2nd edn., The Newman Bookshop, Westminster, 1947).

Anderson, M.O., Kings and Kingship in Early Scotland (Scottish Academy Press, Edinburgh, 1973).

Anson, Sir William, The Law and Custom of the Constitution ed. A.B. Keith (5th edn., 1922, Clarendon Press, Oxford; 3rd edn., 1907).

Archie, Carol, Maori Sovereignty: The Pakeha Perspective (Hodder Moa Beckett, Auckland, 1995).

Arnold, John et al (eds.), Out of Empire: The British Dominion of Australia (Mandarin Australia, Victoria, 1993).

Atkinson, Alan, The Muddle-Headed Republic (Oxford University Press, Melbourne, 1993).

Auckland District Law Society Public Issues Committee, The Holyoake Appointment (Auckland District Law Society, Auckland, 1977).

Awatere, Dona, Maori Sovereignty (Broadsheet, Auckland, 1984).

Axton, Marie, The Queen's Two Bodies; Drama and the Elizabethan Succession (Royal Historical Society, London, 1977).

Baker, Sir John, An Introduction to English Legal History (2nd edn., Butterworths, London, 1979).

Baker, Sir John, An Introduction to English Legal History (3rd edn., Butterworths, London, 1990).

Baldwin, David, The Chapel Royal: Ancient and Modern (Duckworth, London, 1990).

Baldwin, J.F., The King's Council in England during the Middle Ages (Clarendon Press, Oxford, 1913).

Barker, Rodney, Political Legitimacy and the State (Clarendon Press, Oxford, 1990).

Barker, Sir Ernest, Reflections on Government (Oxford University Press, London, 1942).

Barlow, Frank, Edward the Confessor (Eyre \& Spottiswoode, London, 1970, first published 1964).

Barlow, Frank, The Feudal Kingdom of England, 1042-1216 (2nd edn., Longmans, London, 1961, first published 1955).

Barlow, Frank, William Rufus (Methuen, London, 1983).

Barnett, Hilaire, Constitutional \& Administrative Law (7th edn., Routledge-Cavendish, London, 2009).

Barrell, A.D.M., The Papacy, Scotland and Northern England, 1342-1378 (Cambridge University Press, Cambridge, 1995).

Barrow, G.W.S., Feudal Britain: The Completion of the Medieval Kingdoms, 1066-1314 (Edward Arnold, London, 1956).

Barrow, G.W.S., Kingship and Unity: Scotland 1000-1306 (Edward Arnold, London, 1981).

Barwick, Sir Garfield, Sir John Did His Duty (Serendip Publishers, Wahroonga, 1983).

Barwick, Sir Garfield, The Monarchy in an Independent Australia (Sir Robert Menzies Lecture Trust, Monash University, Melbourne, 1982). 
Beetham, David, The Legitimation of Power (Humanities Press International, Atlantic Highlands, 1991).

Bellamy, J.G., The Law of Treason in England in the Later Middle Ages (Cambridge University Press, Cambridge, 1970).

Benemy, F.W.G., The Queen Reigns She Does Not Rule (George Harrap, London, 1963).

Berger, Carl (ed.), Imperialism and Nationalism, 1884-1914: A Conflict in Canadian Thought (Copp Clark, Toronto, 1969).

Birch, Anthony, Coalition Government in Western Europe (Heineman, London, 1983).

Birch, Anthony, Representative and Responsible Government (George Allen \& Unwin, London, 1964).

Birch, Anthony, The British System of Government (9th edn., Routledge, London, 1993).

Bogdanor, Vernon, The Monarchy and the Constitution (Clarendon Press, Oxford, 1995).

Bonner, Hypatia Bradlaugh, Charles Bradlangh: A Record of His Life and Work by his Daughter Hypatia Bradlaugh Bonner, with an account of his Parliamentary struggles, politics and teachings by John M Robertson (2nd edn., T. Fisher Unwin, London, 1895).

Border, J., Church and state in Australia, 1788-1872: a constitutional study of the Church of England in Australia (S.P.C.K., London, 1962).

Boston, Jonathon, The future of cabinet government in New Zealand: The implications of $M$. M.P. for the formation, organization and operation of the cabinet (Graduate School of Business and Government Management, Victoria University of Wellington, Wellington, 1994).

Bradley, A.W. \& K.D. Ewing, Constitutional and Administrative Law (14th edn, Pearson, Harlow, 2007).

Bradley, A.W., K.D. Ewing \& C.J.S. Knight, Constitutional and Administrative Law (16th edn, Pearson, Harlow, 2015).

Bradley, Ian, God Save the Queen: The spiritual dimension of monarchy (Darton, Longman \& Todd, London, 2002).

Brady, Alexander, Democracy in the Dominions: A comparative Study of Institutions (3rd edn., University of Toronto Press, Toronto, 1958).

Brazier, Rodney, Constitutional Practice: The Foundations of British Government (2nd edn., Oxford University Press, London, 1995).

Brazier, Rodney, Constitutional Reform: Reshaping the British Constitution (Oxford University Press, London, 1991).

Brazier, Rodney, Ministers of the Crown (Clarendon Press, Oxford, 1997).

Brookfield, F.M., Waitangi and Indigenous Rights: Revolution, Law and Legitimation (University of Auckland Press, Auckland, 1999).

Brown, R.A., Origins of English Feudalism (George Allen \& Unwin, New York, 1973).

Brown, R.A., The Norman Conquest (Edward Arnold, London, 1984).

Brownlie, Ian, Treaties and Indigenous Peoples: The Robb Lectures 1991 ed. F.M. Brookfield (Clarendon Press, Oxford, 1992).

Brundage, James A., Medieval Canon Law (Longman, London, 1995).

Buick, Lindsay, The Treaty of Waitangi: How New Zealand became a British Colony (Avery, New Plymouth, 1933).

Burgess, Glenn, The Politics of the Ancient Constitution (Pennsylvania State Press, Philadelphia, 1993).

Butler, David \& D.A. Low (eds.), Sovereigns and Surrogates: Constitutional Heads of State in the Commonwealth (Macmillan, London, 1991).

Campbell, James, Essays in Anglo-Saxon History (Hambledon Press, London, 1986). 
Cannon, John \& Ralph Griffiths, The Oxford Illustrated History of the British Monarchy (Oxford University Press, Oxford, 1988).

Carlyle, Sir Robert \& A.J. Carlyle, A History of Medicval Political Theory in the West (Blackwood, Edinburgh, 1903-1936).

Cary, Max and Howard H. Scullard, A history of Rome down to the reign of Constantine (3rd edn., Macmillan, London, 1975).

Chadwick, Roger, Bureaucratic mercy: the Home Office and the treatment of capital cases in Victorian Britain (Garland, London/New York, c.1992).

Chalmers, Dalzell \& Hon. CyrilAsquith, Outline of Constitutional Law (4th edn., Sweet \& Maxwell, London, 1930).

Chamber, David, Faculty Office Registers, 1534-1549: A Calendar of the First Two Registers of the Archbishop of Canterbury's Faculty Office (Clarendon Press, Oxford, 1966).

Chamberlain, Joseph, The Radical Programme (Harvester Press, London, 1971).

Cheshire, G.C., Modern Law of Real Property ed. E.H. Burn (13th edn., Butterworths, London, 1982).

Chester, D.N. \& Nona Bowring, Questions in Parliament (Clarendon Press, Oxford, 1962).

Chrimes, S.B., English Constitutional History (4th edn., Oxford University Press, London, 1967, first published 1948).

Chrimes, S.B., English Constitutional Ideas in the Fifteenth Century (Cambridge University Press, Cambridge, 1936).

Chrimes, S.B., Lancastrians, Yorkists and Henry VII (2nd edn., Macmillan \& Co. Ltd, London, 1966, first published 1964).

Chrimes, S.B., Ross, C.D. \& R.A. Griffiths (eds.), Fifteenth-century England 1399-1509 (Manchester University Press, Manchester, 1972).

Christie, I.R., Wars and Revolutions: Britain, 1760-1815 (Edward Arnold, Cambridge, Massachusetts, 1982).

Clanchy, M.T., England and its Rulers, 1066-1272: Foreign Lordship and National Identity (Fontana, London, 1983).

Clark, Bruce, Native liberty, Crown Supremacy - the Existing Aboriginal Right of Self-Government in Canada (McGill-Queen's University Press, Montreal, 1990).

Clements, Frank, Rhodesia: The Course to Collision (Pall Mall Press, London, 1969).

Collins, Randall, Weberian Sociological Theory (Cambridge University Press, Cambridge, 1986).

Coward, B., The Stuart Age (2nd edn., Longman, London, 1994, first published 1980).

Cowen, Sir Zelman, A Touch of Healing, speeches by Sir Zelman Cowen (University of Queensland Press, St. Lucia, 1986).

Cowen, Sir Zelman, Isaac Isaacs (Oxford University Press, Melbourne, 1967).

Cox, Lindsay, Kotahitanga: the search for Maori political unity (Oxford University Press, Auckland, 1993).

Cox, Noel, A Constitutional History of the New Zealand Monarchy: The evolution of the New Zealand monarchy and the recognition of an autochthonous polity (V.D.M. Verlag Dr. Müller Aktiengesellschaft \& Co. K.G., Saarbrücken, 2008).

Cox, Noel, Church and State in the Post-Colonial Era: The Anglican Church and the Constitution in New Zealand (Polygraphia (NZ) Ltd, Auckland, 2008).

Cox, Noel, Constitutional paradigms and the stability of states (Ashgate Publishing Ltd, Aldershot, 2011).

Cox, Noel, Technology and Legal Systems (Ashgate Publishing Ltd, Aldershot, 2006). 
Cox, Noel, The catholicity of ordained ministry in the Anglican Communion: An examination of the ecclesiology implicit in the validity of orders debate (V.D.M. Verlag Dr. Müller Aktiengesellschaft \& Co. K.G., Saarbrücken, 2009).

Cramsie, John, Kingship and Crown finance under James VI and I, 1603-1625 (Royal Historical Society, London, 2002).

Crossman, Richard, The Diaries of a Cabinet Minister (Hamish Hamilton, London, 1977).

Cunneen, Christopher, King's Men: Australia's Governors-General from Hopetoun to Isaacs (George Allen \& Unwin Australia, North Sydney, 1983).

Curzon of Kedleston, George Marquess, British Government in India: the story of the viceroys and government houses (Cassell, London, 1925).

d'Entrèves, A. Passerin, The Notion of the State: An Introduction to Political Theory (Clarendon Press, Oxford, 1967).

Dale, Sir William, The Modern Commonwealth (Butterworths, London, 1983).

Dawson, R. MacGregor, The Civil Service of Canada (Oxford University Press, Oxford, 1929).

Dawson, R. MacGregor, The Development of Dominion Status, 1900-1936 (Cass, London, 1937).

de Smith, S.A., Constitutional and Administrative Law (2nd edn., Penguin, London, 1971).

de Smith, S.A., Constitutional and Administrative Law (3rd edn., Penguin, London, 1977).

de Smith, S.A., Constitutional and Administrative Law ed. Harry Street \& Rodney Brazier (5th edn., Penguin Books, London, 1985).

de Smith, S.A. \& Rodney Brazier, Constitutional and Administrative Law (7th edn., Penguin Books, London, 1994).

Derry, J.W., The Regency Crisis and the Whigs, 1788-9 (Cambridge University Press, Cambridge, 1963).

Devlin, Lord Patrick, The Enforcement of Morals (Oxford University Press, London, 1959).

Dicey, Albert, Introduction to the Study of the Law of the Constitution introduction \& appendix by E.C.S. Wade (10th edn., Macmillan, London, 1959, 9th edn., 1950, 8th edn., 1915 reprinted 1926, first published 1885).

Dilke, Sir Charles, On the cost of the Crown (G. Shield, London, 1871).

Doe, Norman, Canon Law in the Anglican Communion (Clarendon Press, Oxford, 1998).

Doe, Norman, Fundamental Authority in Late Medieval English Law (Cambridge University Press, Cambridge, 1990).

Doern, G.B. \& R.W. Phidd, Canadian Public Policy (Methuen, Toronto, 1983).

Dogan, Mattei \& Domonique Pelassy, How to Compare Nations: Strategies in Comparative Politics (Chatham House, New Jersey, 1984).

Dozier, Robert, For King, Constitution and Country - the English Loyalists and the French Revolution (University Press of Kentucky, Lexington, 1983).

Dunleavy, P. \& B. O'Leary, Theories of the State (Macmillan, London, 1987).

Dunn, John, The Political Thought of John Locke: An historical account of the Two Treatises of Government (Cambridge University Press, London, 1969).

Eddy, John \& Deryck Schreuder, The Rise of Colonial Nationalism: Australia, New Zealand, Canada and South Africa First Assert Their Nationalities, 1880-1914 (Allen \& Unwin, Sydney, 1988). 
Edge, I. (ed.), Comparative law in global perspective: essays in celebration of the fiftieth anniversary of the founding of the SOAS Law Department (Transnational Publishers, Ardsley, 2000).

Elliott, David R. \& Iris Miller, Bible Bill: A Biography of William Aberhart (Reidmore Books, Edmonton, 1987).

Elton, Sir Geoffrey, Reform and Reformation, 1509-1558 (Edward Arnold, London, 1979).

Emerson, Rupert, From Empire to Nation: The Rise to Self-Assertion of Asian and African Peoples (Beacon Press, Boston, 1960).

Enever, F.A., Bona Vacantia under the Law of England (H.M.S.O., London, 1927).

Errington, Jane, The Lion, the Eagle, and Upper Canada: A Developing Colonial Ideology (McGill-Queen's University Press, Kingston, 1987).

Erskine May, Sir Thomas, Constitutional History of England (Longman, Green \& Co., New York, 1912, first published 1861-1863).

Erskine May, Sir Thomas, Parliamentary Practice ed. C.J. Boulton (21st edn., Butterworths, London, 1989).

Erskine May, Sir Thomas, Treatise on the Law, Privileges, Proceedings and Usage of Parliament ed. Sir Charles Gordon (20th edn., Butterworths, London, 1983).

Evans, Gareth, McMillan, John \& Haddon Storey, Australia's Constitution - Time for a Change? (Allen \& Unwin, Sydney, 1983).

Evatt, Herbert, The King and His Dominion Governors (2nd edn., Frank Cass, London, 1967).

Evatt, Herbert, The Royal Prerogative commentary by Leslie Zines (The Law Book Co., Sydney, 1987).

Evatt, Herbert Vere \& Eugene Alfred Forsey, Evatt and Forsey on the Reserve Powers (Legal Books, Sydney, 1990).

Fawcett, J.E.S., The British Commonwealth in International Law (Stevens, London, $1963)$.

Feilden, H., A Short Constitutional History of England (5th edn., F.B. Rothman, Littleton, Colorado, 1985, 4th edn., 1911, 3rd edn., Blackwell, Oxford, 1908, first published 1882).

Femia, Joseph, Hegemony and Consciousness of the thought of Antonio Gramsci (Clarendon Press, Oxford, 1981).

Figgis, J.N., The theory of the Divine Right of Kings (2nd edn., Cambridge University Press, Cambridge, 1914).

Finnis, John, The unconstitutionality of the Supreme Court's prorogation judgment (Policy Exchange, London, 2019).

Fleming, Robin, Kings and Lords in Conquered England (Cambridge University Press, Cambridge, 1991).

Foden, N.A., The Constitutional Development of New Zealand in the First Decade (L.T. Watkins, Wellington, 1938).

Foley, Michael, The Silence of Constitutions: Gaps, 'Abeyances' and Political Temperament in the Maintenance of Government (Routledge, London, 1989).

Foot, B., Dismissal of a Premier - The Sir Philip Game Papers (Morgan Publications, Sydney, 1968).

Forsey, Eugene, The Royal Power of Dissolution of Parliament in the British Commonwealth (Oxford University Press, Toronto, 1968, reprint of 1943).

Forsyth, William, Cases and Opinions on Constitutional Law: And Various Points of English Jurisprudence (Stevens and Haynes, London, 1869). 
Fox-Davies, A.C., A Complete Guide to Heraldry revised by J.P. Brooke-Little (Bloomsbury Books, London, 1985).

Frame, Robin, The Political Development of the British Isles 1100-1400 (Oxford University Press, Oxford, 1990).

Frankland, Noble, Prince Henry, Duke of Gloucester (Weidenfeld \& Nicolson, London, 1980).

Fraser, Andrew, The Spirit of the Laws: Republicanism and the Unfinished Project of Modernity (University of Toronto Press, Toronto, 1990).

Ganshof, Francois, Feudalism trans. Philip Grierson (Longman, London, 1952, first published 1944).

Gardiner, Samuel, History of England from the Accession of James I to the Outbreak of the Civil War, 1603-1642 (Longmans, Green \& Company, London, 1883-1884, 1896-1901, 1904-1908).

Garran, Sir Robert, Prosper the Commonwealth (Angus \& Robertson, Sydney, 1958).

Gibson, William, James II and the Trial of the Seven Bishops (Palgrave Macmillan, London, 2009).

Gillingham, J. \& J.C. Holt (eds.), War and Government in the Middle Ages (Boydell Press, Cambridge, 1984).

Gloucester, Alice, Duchess of, The Memoirs of Princess Alice Duchess of Gloucester (Collins, London, 1983).

Gluckman, M., Politics law and ritual in tribal society (Oxford University Press, Oxford, 1977).

Gneist, von, Heinrich, History of the English Constitution (William Clowes \& Sons, London, 1885, first published 1882 as Englische Verfassungsgeschichte).

Goldsmith, Paul, John Banks, A biography (Penguin, Auckland, 1997).

Gough, J.W., Fundamental law in English Constitutional History (Clarendon Press, Oxford, 1955).

Grainger, Gareth \& Kerry Jones (eds.), The Australian Constitutional Monarchy (A.C.M. Publishing, Sydney, 1994).

Hagen, Ann, Anglo-Saxon Food and Drink: Production, Processing, Distribution and Consumption (Anglo-Saxon Books, Hockwold-cum-Wilton, 2006).

Halstead, J.P., The Second British Empire: Trade, Philanthropy, and Good Government, 1820-1890 (Greenwood Press, Westport, 1983).

Hardie, Frank, The Political Influence of Queen Victoria, 1861-1901 (Oxford University Press, London, 1935).

Hardie, Frank, The Political Influence of the British Monarchy 1868-1952 (Batsford, London, 1970).

Hardin, I. \& N. Lewis, The Noble Lie: The British Constitution and the Role of Law (Hutchinson, London, 1987).

Hasluck, Sir Paul, The Government and the People, 1939-1941 (Australian War Memorial, Canberra, 1952).

Hasluck, Sir Paul, The Government and the People, 1942-1945 (Australian War Memorial, Canberra, 1970).

Hasluck, Sir Paul, The Office of Governor-General (Melbourne University Press, Carlton, 1979).

Hayek, von, Friedrich, Law, Legislation and Liberty (Routledge \& Kegan Paul, London, 1982).

Hayek, von, Friedrich, The Constitution of Liberty (Routledge \& Kegan Paul, London, 1960). 
Hayek, von, Friedrich, The Road to Serfdom (2nd edn., Routledge \& Kegan Paul, London, 1962).

Heard, Andrew, Canadian Constitutional Conventions: The Marriage of Law and Politics (Oxford University Press, Toronto, 1991).

Hearn, William, The Government of England: Its Structure and its Development (Longmans, Green, Reader and Dyer, London, 1867).

Heaton, David, James Warden \& Bill Gammage (eds.), Crown or Country - the traditions of Australian Republicanism (Allen \& Unwin, St. Leonards, N.S.W., 1994).

Held, D., Political Theory and the Modern State (Polity Press, Cambridge, 1989).

Henning, Basil, The History of Parliament (Secker \& Warburg, London, 1983) 3 Vols.

Heuston, Robert, Essays in Constitutional Law (2nd edn., Stevens \& Son, London, 1964).

Hinde, G.W., D.W. McMorland \& P.B.A. Sim, Land Law (Butterworths, Wellington, 1978).

Hinsley, F., Sovereignty (2nd edn., Cambridge University Press, Cambridge, 1986).

Hintz, O.S. (ed.), Lord Cobham's Speeches (Wilson \& Horton, Auckland, 1962).

Hirst, D., Authority and Conflict, 1603-1658 (E. Arnold, London, 1986).

Hirst, John, A Republican Manifesto (Oxford University Press, Melbourne, 1994).

Hobsbawn, Eric, Nations and Nationalism since 1780: Programme, Myth, Reality (2nd edn., Cambridge University Press, Cambridge, 1992).

Hobsbawn, Eric \& Terence Ranger (eds.), The Invention of Tradition (Cambridge University Press, Cambridge, 1983).

Hogg, P.W., Constitutional Law of Canada (3rd edn., Carswell, Scarborough, Ontario, 1992).

Hogg, P.W., Liability of the Crown in Australia, New Zealand and the United Kingdom (The Law Book Co., Sydney, 1971).

Hogue, Arthur, Origins of the Common Law (Indiana University Press, Bloomington, 1966).

Holdsworth, Sir William, A History of English Law (Methuen \& Co., London, 1924), Vol. VI.

Holdsworth, Sir William, A History of English Law (6th edn., Methuen \& Co., London, 1938), Vol. X.

Holt, Sir James, Magna Carta and Medieval Government (Hambledon, London, 1985).

Honderich, Ted (ed.), The Oxford Companion to Philosophy (Oxford University Press, Oxford, 1995).

Honoré, Antony, Making Law Bind (Clarendon Press, Oxford, 1987).

Horne, Donald et al, The Coming Republic (Pan Macmillan, Sydney, 1992).

Howard, Colin, Australian Federal Constitutional Law (3rd edn., Law Book Co. Ltd, Sydney, 1985).

Hudson, W.J. \& M.P. Sharp, Australian Independence: Colony to Reluctant Kingdom (Melbourne University Press, Melbourne, 1988).

Innis, Harold, Political Economy in the Modern State (Ryerson Press, Toronto, 1946).

Jackson, Keith, Dilemma of Parliament (Allen \& Unwin, Wellington, 1987).

Jackson, Keith, New Zealand Legislative Council: a study of the establishment, failure and abolition of an Upper House (University of Otago Press, Dunedin, 1972).

Jackson, Keith \& Alan McRobie, New Zealand adopts proportional representation: accident? design? evolution? (Brookfield, Aldershot, 1998).

Jackson, Moana, The Maori and the Criminal Justice System: A New Perspective: Te Whaipaanga Hou (Part 2) (Department of Justice, Wellington, 1988).

Jacob, E.F., The Fifteenth Century (Oxford University Press, London, 1961). 
Jacobs, Joseph, The Republican Crown: Lawyers and the Making of the State in Twentieth Century Britain (Dartmouth, Aldershot, 1996).

Jarman, Thomas, Jarman on Wills ed. Charles Sanger (7th edn., Sweet \& Maxwell, London, 1930).

Jennings, Sir Ivor, Cabinet Government (3rd edn., Cambridge University Press, Cambridge, 1959, first published 1936).

Jennings, Sir Ivor, Constitutional Laws of the Commonwealth (3rd edn., Clarendon Press, Oxford, 1957).

Jennings, Sir Ivor, Constitutional Problems in Pakistan (Cambridge University Press, Cambridge, 1957).

Jennings, Sir Ivor, The Law and the Constitution (5th edn., University of London Press, London, 1959).

Jennings, Sir Ivor, The Queen's Government (Penguin, London, 1964, first published 1954).

Jolliffe, J.E.A., Angevin Kingship (2nd edn., Adam \& Charles Black, London, 1963, first published 1955).

Jolliffe, J.E.A., The Constitutional History of Medieval England (4th edn., Norton, New York, 1961, first published 1937).

Jennings, Robert, The Acquisition of Territory in International Law (University of Manchester Press, Manchester, 1963).

Jennings, Robert \& Arthur Watts, Oppenheim's International Law (9th edn., Longman, Essex, 1992).

Jones, R.H., The Royal Policy of Richard II: Absolutism in the Later Middle Ages (Blackwell, Oxford, 1968).

Joseph, Philip, Constitutional and Administrative Law in New Zealand (The Law Book Co., North Ryde, Sydney, 1993).

Joseph, Philip, Essays on the Constitution (Butterworths, London, 1995).

Kantorowicz, Ernst, The King's Two Bodies: A Study in Mediaval Political Theology (Princeton University Press, Princeton, 1957).

Kawharu, Sir Hugh (ed.), Waitangi: Maori and Pakeha Perspectives of the Treaty of Waitangi (Oxford University Press, Auckland, 1989).

Keeton, G.W., The Norman Conquest and the Common Law (Benn, London, 1966).

Keir, Sir David Lindsay, The Constitutional History of Modern Britain since 1485 (8th edn., van Nostrand, Princeton, 1966).

Keith, A.B., An Introduction to British Constitutional Law (Clarendon Press, Oxford, 1931).

Keith, A.B., Constitutional History of the First British Empire (Clarendon Press, Oxford, 1930).

Keith, A.B., Constitutional Law of the British Dominions (Macmillan, London, 1933).

Keith, A.B., Responsible Government in the Dominions (2nd edn., Clarendon Press, Oxford, 1928).

Keith, A.B., The British Cabinet System, 1830-1938 (Stevens \& Son, London, 1939).

Keith, A.B., The Constitution of England from Queen Victoria to George VI (Macmillan, London, 1940).

Keith, A.B., The Dominions as Sovereign States (Macmillan, London, 1938).

Keith, A.B., The Governments of the British Empire (1935).

Keith, A.B., The King and the Imperial Crown: The Powers and Duties of His Majesty (Longmans Green, London, 1936).

Kelsey, Jane, Rolling Back the State: Privatisation of Power in Aotearoa/New Zealand (Bridget Williams Books, Wellington, 1993). 
Kendle, J.E., The Colonial and Imperial Conferences 1887-1911: A study in Imperial organisation (Longman, London, 1967).

Keneally, Thomas, Our Republic (William Heinemann Australia, Victoria, 1993).

Kerr, Sir John, Matters for Judgment: An Autobiography (Macmillan, London, 1978).

Kornberg, Allan \& Harold Clarke, Citizens and Community - Political Support in a Representative Democracy (Cambridge University Press, Cambridge, 1992).

Körner, Sten, The Battle of Hastings, England and Europe 1035-1066 (C.W.K. Gleerup, Lund, 1964).

La Nauze, J.A., The Making of the Australian Constitution (Melbourne University Press, Melbourne, 1972).

Lander, J.R., The Limitations of English Monarchy in the Later Middle Ages (University of Toronto Press, Toronto, 1989).

Landsman, N.C., Nation and Province in the First British Empire: Scotland and the Americas, 1600-1800 (Bucknell University Press, Cranbury, 2001).

Larmour, Peter, Legitimacy, Sovereignty and Regime Change in the South Pacific: Comparisons Between the Fiji Coups and the Bougainville Rebellion (Australian National University Press, Canberra, 1992).

Laski, Harold, Authority in the Modern State (Yale University Press, New Haven, 1919).

Laski, Harold, Studies in the Problems of Sovereignty (Yale University Press, New Haven, 1917).

Latham, Richard, The Law and the Commonwealth (London, 1949) reprinted from W.K. Hancock (ed.), Survey of British Commonwealth Affairs (Oxford University Press, London, 1937).

Lee, Sir Sidney, King Edward VII: A Biography (Macmillan, London, 1925).

Lefroy, Augustus, Short Treatise on Canadian Constitutional Law (Carswell, Toronto, 1918).

Levy-Ullmann, Henri, The English Legal Tradition: Its Sources and History ed. Frederick Goadly; trans. M. Mitchell rev. (Macmillan, London, 1935).

Lewis, C.B., Judicial Remedies in Public Law (Sweet \& Maxwell, London, 1991).

Leyland, Peter \& Gordon Anthony, Textbook on Administrative Law (6th edn., Oxford University Press, Oxford, 2007).

Lindley, Sir Mark, The Acquisition and Government of Backward Territories in International Law: Being a treatise on the law and practice relating to colonial expansion (Negro Universities Press, New York, 1969, reprint of 1926 edition).

Lipset, Seymour Martin, Political Man: The Social Bases of Politics (Doubleday, Garden City, New York, 1960).

Loon, von, Richard \& Michael Whittington, The Canadian Political System: Environment, Structure and Process (3rd edn., McGraw-Hill Ryerson, Toronto, 1981).

Loveland, Ian, Constitutional Law, Administrative Law, and Human Rights: A Critical Introduction (5th edn., Oxford University Press, Oxford, 2009).

Lowell, Colin Rhys, English Constitutional and Legal History (Oxford University Press, New York, 1962).

Lucy, R., The Australian Form of Government (Macmillan, Melbourne, 1985).

Lumb, R. Darrell \& K.W. Ryan, The Constitution of the Commonwealth of Australia Annotated (3rd edn., Butterworths, Sydney, 1981).

Lyon, Bryce, A Constitutional and Legal History of Medieval England (2nd edn., W.W. Norton \& Company, New York, 1980).

Mackinnon, Frank, The Crown in Canada (McClelland \& Stewart West, Calgary, 1976).

Madden, F. \& Fieldhouse, D. (eds.), The Classical Period of the First British Empire, 1689-1783: The Foundations of a Colonial System of Government: Select Documents on the 
Constitutional History of the British Empire and Commonwealth (Greenwood Publishing Group, Westport, 1985).

Magnus, Sir Philip, Gladstone: A Biography (Murray, London, 1954).

Maine, Sir Henry Sumner, Early Law and Custom (John Murray, London, 1890).

Maitland, Frederic, Domesday Book and Beyond - three essays on the early history of England (Norton, New York, 1966, first published 1897).

Maitland, Frederic, The Constitutional History of England - a course of lectures ed. H.A.L.

Fisher (Cambridge University Press, London, 1965, first published 1908).

Maitland, Frederic \& Sir FrederickPollock, History of English Law before the Times of Edward I (2nd edn., Cambridge University Press, Cambridge, 1895).

Mann, F.A. Foreign Affairs in English Courts (Oxford University Press, Oxford, 1986).

Mansergh, Nicholas, The Commonwealth Experience (Weidenfeld \& Nicolson, London, 1969).

Markesinis, Basil S., The theory and practice of dissolution of Parliament (Cambridge University Press, Cambridge, 1972).

Markwell, Donald J., Constitutional Conventions and the Headship of State: Australian Experience (Connor Court, Redland Bay, 2016).

Markwell, Donald J., The Crown and Australia (University of London, London, 1987, reprinted by The Monarchist League, London, 1990).

Marsden, R.G., Documents relating to the Law and Custom of the Sea, 1649-1767 (Navy Records Society, London, 1916), Vol. II.

Marshall, Geoffrey, Constitutional Conventions - The Rules and Forms of Political Accountability (Oxford University Press, Oxford, 1984, reprinted 1986).

Marshall, Geoffrey, Constitutional Theory (Clarendon Press, Oxford, 1971).

Marshall, Geoffrey, Parliamentary Sovereignty and the Commonwealth (Oxford University Press, Oxford, 1957).

Marshall, Geoffrey \& G.C. Moodie, Some Problems of the Constitution (5th edn., Hutchinson, London, 1971).

Mason, Emma, Norman Kingship (Headstart History, Bangor, 1991).

Massey, Vincent, What is past is prologue: The memoirs of the Right Honourable Vincent Massey, Ch. (Macmillan, London, c.1963).

McGibbon, Ian, Blue-water Rationale; the Naval Defence of New Zealand 1914-1942 (Government Printer, Wellington, 1981).

McHugh, P.G., The Maori Magna Carta: New Zealand Law and the Treaty of Waitangi (Oxford University Press, Auckland, 1991).

McKenna, Mark, The Captive Republic: A History of Republicanism in Australia, 1788-1996 (Cambridge University Press, Cambridge, 1997).

McKinnon, Malcolm, Independence and Foreign Policy: New Zealand in the world since 1935 (Auckland University Press, Auckland, 1993).

McLeay, Elizabeth, The Cabinet and Political Power in New Zealand (Oxford University Press, Auckland, 1995).

McLintock, A.H., Crown Colony Government in New Zealand (Government Printer, Wellington, 1958).

McNair, Arnold, Lord, The Law of Treaties (Clarendon Press, Oxford, 1961).

McNeil, Kent, Common Law Aboriginal Title (Clarendon Press, Oxford, 1989).

McWhinney, Edward, Canada and the Constitution, 1979-1982: Patriation and the Charter of Rights (University of Toronto Press, Toronto, 1982).

Medley, D.J., A Students Manual of English Constitutional History (6th edn., Macmillan, New York, 1925, first published 1894). 
Melbourne, Hineani, Maori Sovereignty: The Maori Perspective (Hodder Moa Beckett, Auckland, 1995).

Menzies, Sir Robert, Afternoon Light: Some memories of people and events (Cassells, Melbourne, 1967).

Milsom, S.F.C., Historical Foundations of the Common Law (2nd edn., Butterworths, London, 1981, first published, 1969).

Moon, Paul, The Origins of the Treaty of Waitangi (Birdwood, Auckland, 1994).

Moore, R.J., Making the New Commonwealth (Oxford University Press, London, 1987).

Moore, Sir William Harrison, Act of State in English Law (John Murray, London, 1906).

Morgan, Edmund, Inventing the People; the Rise of Popular Sovereignty in England and America (Norton, New York, 1988).

Mulgan, Richard, Democracy and Power in New Zealand: A study of New Zealand politics (2nd edn., Oxford University Press, Auckland, 1989).

Mulgan, Richard, Politics in New Zealand (2nd edn., Auckland University Press, Auckland, 1997).

Munro, Colin, Studies in Constitutional Law (Butterworths, London, 1987).

Nairn, Tom, The Enchanted Glass: Britain and its Monarchy (Radius, London, 1988).

Namier, Lewis, Monarchy and the Party System (Clarendon Press, Oxford, 1952) Romanes lecture.

Nelson, Janet L., Politics and Ritual in early Medieval Europe (Hambledon Press, London, 1986).

Nenner, Howard, The Right to be King - The Succession to the Crown of England, 1603-1714 (Macmillan, London, 1995).

Neuendorff, Gwen, Studies in the Evolution of Dominion Status: The Governor Generalship of Canada and the Development of Canadian Nationalism (George Allen \& Unwin, London, 1942).

Nicolson, Hon. Sir Harold, King George the Fifth His Life and Reign (Constable \& Co., London, 1952).

O'Connell, Daniel \& Ann Riordan, Opinions on Imperial Constitutional Law (The Law Book Co., Sydney, 1971).

Orange, Claudia, Treaty of Waitangi (Allen \& Unwin, Wellington, 1987).

Palmer, Sir Geoffrey, New Zealand's Constitution in Crisis - Reforming our Political System (John McIndoe, Dunedin, 1992).

Palmer, Sir Geoffrey, Unbridled Power: An Interpretation of New Zealand's Constitution and Government (2nd edn., Oxford University Press, Wellington, 1987).

Palmer, Sir Geoffrey \& Matthew Palmer, Bridled Power - New Zealand Government under M.M.P. (3rd edn., Oxford University Press, Auckland, 1997).

Partington, Geoffrey, The Australian Nation - Its British and Irish Roots (Australian Scholarly Publishing, Kew, 1994).

Pennington, Kenneth, The Prince and the Law, 1200-1600; Sovereignty and rights in the Western legal tradition (University of California Press, Berkeley, 1993).

Perry, Paul \& Alan Webster, New Zealand Politics at the Turn of the Millennium: Attitudes and Values about Politics and Government (Alpha Publications, Auckland, 1999).

Petit-Dutailles, C.H., The Feudal Monarchy in France and England from the Tenth to the Thirteenth Century ed. \& trans. E.D. Hunt (Routledge \& Kegan Paul, London, 1936) The History of Civilisation Series ed. C.K. Ogden.

Petit-Dutailles, C.H. \& Georges Lefebvre, Studies and Notes supplementary to Stubb's Constitutional History (2nd edn., Manchester University Press, London, 1930, first published 1923).

Pettit, P.H., Equity and the Law of Trusts (5th edn., Butterworth \& Co, London, 1984). 
Pocock, J.G.A., The Ancient Constitution and the Feudal Law; A Study of English Historical Thought in the Seventeenth Century (2nd edn., Cambridge University Press, Cambridge, 1987).

Potter, H., Potter's Outlines of English Legal History ed. A.K.R. Kiralfy (5th edn., Sweet \& Maxwell, London, 1958).

Quentin-Baxter, Alison \& Janet McLean, This Realm of New Zealand: The Sovereign, the Governor-General, the Crown (Auckland University Press, Auckland, 2018).

Raeside, James, Sovereign Chief, A Biography of Baron de Thierry (Caxton Press, Christchurch, 1977).

Rawls, John, Political Liberalism (Columbia University Press, New York, 1993).

Renwick, William (ed.), Sovereignty and indigenous rights: The Treaty of Waitangi in international contexts (Oxford University Press, Wellington, 1991).

Reynolds, Henry, The Law of the Land (Penguin, Harmondsworth, 1987).

Rhys Lovell, Colin, English Constitutional and Legal History - A Survey (Oxford University Press, New York, 1962).

Ridges, E.W., Constitutional Law of England ed. G.A. Forrest (8th edn., Stevens, London, 1950, first published 1905).

Roberts-Wray, Sir Kenneth, Commonwealth and Colonial Law (Stevens, London, 1966).

Robertson, George, The Law and Practice of Civil Proceedings, by and Against the Crown and Departments of the Government, with Numerous Forms and Precedents (Stevens, London, 1908).

Rolph, C.H., The Queen's Pardon (Cassell, London, 1978).

Rose, Kenneth, Kings, Queens and Courtiers: Intimate Portraits of the Royal House of Windsor from its foundation to the Present Day (Weidenfeld \& Nicolson, London, 1985).

Ross, Lloyd, John Curtin: A biography (Macmillan, London, 1977).

Rousas, John Rushdoony, The Institutes of Biblical Law (Presbyterian and Reformed Publishing, 1973).

Russell, Peter, Constitutional Odyssey: Can Canadians become a Sovereign People? (University of Toronto Press, Toronto, 1992).

Rutherford, J., The Treaty of Waitangi and the Acquisition of British Sovereignty in New Zealand (Auckland University College, Auckland, 1949).

Sanborn, F.R., Origins of Early English Maritime and Commercial Law (Century, London, 1930).

Sawer, Geoffrey, The Australian Constitution (2nd edn., Australian Government Publishing Service, Canberra, 1988).

Schwarzenberger, George, A Manual of International Law (5th edn., London Institute of World Affairs/Stevens \& Sons, London, 1967).

Scott, Jonathan, Algernon Sidney and the Restoration Crisis, 1677-1683 (Cambridge University Press, Cambridge, 1991).

Scott, K.J., The New Zealand Constitution (Oxford University Press, Oxford, 1962).

Seeley, J.R., The Expansion of England (Macmillan, London, 1883).

Sexton, Brendan, Ireland and the Crown, 1922-1936: The Governor-General of the Irish Free State (Irish Academic Press, Blackrock, Dublin, 1989).

Sharp, Andrew (ed.) Leap into the dark: the changing role of the state in New Zealand since 1984 (Auckland University Press, Auckland, 1994).

Sharp, Andrew, Justice and the Maori: the philosophy and practice of Maori claims in New Zealand since the 1970s (2nd edn., Oxford University Press, Auckland, 1997).

Sharpe, Kevin, The Personal Rule of Charles I (Yale University Press, New Haven, 1992).

Shaw, A.G.L. (ed.), Great Britain and the Colonies, 1815-1865 (Methuen, London, 1970). 
Shaw, Malcolm, Title to Territory in Africa (Clarendon Press, Oxford, 1985).

Sheehan, Michael, The Will in Medieval England from the conversion of the Anglo-Saxons to the End of the thirteenth century (Pontifical Institute of Medixval Studies, Toronto, $1963)$ Studies and texts 6.

Simpson, Alan (ed.), Constitutional Implications of M.M.P. (School of Political Science and International Relations, Victoria University of Wellington, Wellington, 1998).

Sinha, Prakash, New Nations and the Law of Nations (Sijthoff, Leyden, 1977).

Skinner, Quentin, Visions of Politics (Cambridge University Press, Cambridge, 2002).

Skocpol, Theda, States and Social Revolution (Cambridge University Press, Cambridge, 1979).

Smith, David E., The Invisible Crown: The First Principle of Canadian Government (University of Toronto Press, Toronto, 1995).

Smith, David E., The Republican Option in Canada, Past and Present (University of Toronto Press, Toronto, 1999).

Smith, H.A. (ed.), Great Britain and the Law of Nations: A selection of documents illustrating the view of the Government of the United Kingdom upon matters of international law (King, London, 1932).

Spath, Franz, Das Bundespräsidialamt (Droste Verlag, Düsseldorf, 1982).

Spender, J.A. \& Hon. CyrilAsquith, Life of Herbert Henry Asquith, Lord Oxford and Asquith (Hutchinson, London, 1932), Vol. I.

Squibb, G.D., The High Court of Chivalry (Clarendon Press, Oxford, 1959).

Stephen, Serjeant Henry, Mr Serjeant Stephen's New Commentaries on the Laws of England (10th edn., Butterworths, London, 1886, first published 1841).

Story, J., Commentaries on the Constitution of the United States: With a preliminary review of the Constitutional History of the colonies and states, before the adoption of the Constitution ed. Melville M. Bigelow (5th edn., William S. Hein \& Co., Buffalo, 1994).

Strayer, J.R., On the Medioval Origins of the Modern State (Princeton University Press, Princeton, 1970).

Strong, Sir Roy, Coronation: A History of Kingship and the British Monarchy (HarperCollins, London, 2005).

Stubbs, Rt. Rev'd. William, The Constitutional History of England in its origin and development (4th edn., Clarendon Press, Oxford, 1906).

Sunkin, Maurice \& Sebastian Payne (eds.), The Nature of the Crown: A Legal and Political Analysis (Oxford University Press, Oxford, 1999).

Susser, Bernard, Approaches to the Study of Politics (Macmillan Publishing, New York, 1992).

Taafahi, Tauassa, Governance in the Pacific: the dismissal of Tuvalu's Governor-General (National Centre of Development Studies, Australian National University, Canberra, 1996).

Taswell-Langmead, Thomas, English Constitutional History, from the Teutonic Conquest to the Present Time ed. A.L. Poole (9th edn., Sweet \& Maxwell, London, 1929).

Taylor, Hannis, Origin and Growth of the English Constitution (Houghton Mifflin \& Co., Boston, 1895).

The Canon Law of the Church of England: Being the Report of the Archbishops' Commission on Canon Law, together with Proposals for a Revised Body of Canons; and a Memorandum Lawful Authority' by the Honourable Mr Justice Vaisey (Society for Promoting Christian Knowledge, London, 1947).

Titman, Sir George (ed.), Dress and Insignia worn at His Majesty's Court ... illustrated by colour and photographic plates... In three parts (Lord Chamberlain's Office, London, 1937). 
Tomkins, Adams, Our Republican Constitution (Hart Publishing, Oxford, 2005).

Trainor, Luke (ed.), Republicanism in New Zealand (Dunmore Press, Palmerston North, 1996).

Twomey, Anne, The Chameleon Crown: The Queen and Her Australian Governors (The Federation Press, Annandale, 2006).

Turnbull, Malcolm, The Reluctant Republic (William Heinemann Australia, Port Melbourne, 1993).

Upton, Simon, The Withering of the State (Allen \& Unwin, Wellington, 1987).

Vernon, R.V. \& N. Mansergh, Advisory Bodies: A Study of their uses in relation to Central Government, 1919-1939 (G. Allen \& Unwin, London, 1940).

Wade, Sir Henry, Q.C. \& A.W. Bradley, Constitutional and Administrative Law (11th edn., Longmans, London, 1993, 8th edn., 1970, first published 1931).

Wade, Sir Henry, Q.C. \& Godfrey Phillips, Constitutional Law (2nd edn., Longman, London, 1935, 8th edn, 1971, first published 1931).

Wade, Sir William, Constitutional Fundamentals (revised edn., Stevens, London, 1989).

Walker, Ranganui, Ka Whawhai Tonu Matou: Struggle Without End (Penguin, London, 1990).

Ward, Norman \& David Smith, Jimmy Gardiner: Relentless Liberal (University of Toronto Press, Toronto, 1990).

Wedgwood, C.V., The Trial of Charles I (Collins, London, 1964, Reprint Society edition, 1966).

Western, J.R., Monarchy and Revolution - the English State in the 1680's (Blandford Press, London, 1972).

Wheare, Sir Kenneth, Government by Committee (Oxford University Press, Oxford, 1955).

Wheare, Sir Kenneth, The Constitutional Structure of the Commonwealth (Clarendon Press, Oxford, 1960).

Wheare, Sir Kenneth, The Statute of Westminster and Dominion Status (5th edn., Oxford University Press, London, 1953).

Wheeler-Bennett, Sir John, King George VI: His Life and Reign (Macmillan, London, 1958).

Whelan, Alan \& Barrie Cook, New Zealand Republic (Niu Pacific, Wellington, c.1997).

Whitaker, Reginald, The Government Party: Organising and Financing the Liberal Party of Canada, 1930-58 (University of Toronto Press, Toronto, 1977).

Whitlam, E. Gough, The Truth of the Matter (Penguin, Harmondsworth, 1979).

Williams, Richard, The Contentious Crown: Public Discussion of the British Monarchy in the Reign of Queen Victoria (Ashgate Publishing, Aldershot, 1997).

Winterton, George, Monarchy to Republic (2nd edn., Oxford University Press, Melbourne, 1994).

Winterton, George, Parliament, the executive and the Governor-General: A Constitutional Analysis (Melbourne University Press, Melbourne, 1983).

Woolf, R.H.L., J. Jowell, A. Le Sueur, I. Hare \& C. Donnelly, De Smith's Judicial Review (7th edn., Sweet \& Maxwell, London, 2013).

Wormuth, Francis, The Royal Prerogative 1603-1649: A Study in English Political and Constitutional Ideas (Cornell University Press, Ithaca, 1939).

Yardley, D.C.M., Introduction to British Constitutional Law (7th edn., Butterworths, London, 1990).

Zhu, Yuan Yi, Putting Royal Assent in Doubt? One Implication of the Supreme Court's Prorogation Judgment (Policy Exchange, London, 2019). 
Yoo, John, The Powers of War and Peace: The Constitution and Foreign Affairs after 9/11 (University of Chicago Press, Chicago, 2005).

Yoo, John, War by Other Means: An Insider's Account of the War on Terror (Atlantic Monthly Press, New York, 2006).

\subsection{Chapters in books}

Aikman, C.C., "Parliament" in J.L. Robson (ed.), New Zealand: The Development of its Laws and its Constitution (2nd edn., Stevens, London, 1967), 40-69.

Aikman, C.C. \& J.L. Robson, "Introduction" to J.L. Robson (ed.), New Zealand: The Development of its Laws and its Constitution (2nd edn., Stevens, London, 1967), 1-39.

Arendt, Hannah, "What was authority" in Carl Friedrich (ed.), Authority (Harvard University Press, Cambridge, Massachusetts, 1958), 81-112.

Ashcraft, Richard, "The Two Treatises and the Exclusion Crisis: The Problem of Lockean Political Theory as Bourgeois Ideology" in J.G.A. Pocock \& Richard Ashcraft (eds.), John Locke (William Andrews Clark Memorial Library, University of California, Los Angeles, 1980), 25-114.

Behrendt, P., "Aboriginal Sovereignty and The Australian Republic" in Irene Moores (ed.), Voices of Aboriginal Australia: Past, Present, Future (Butterfly Books, Springwood, N.S. W., 1995), 398-405.

Bercuson, David \& Barry Cooper, "From Constitutional Monarchy to Quasi Republic: The Evolution of Liberal Democracy in Canada" in Janet Ajzenstat (ed.), Canadian Constitutionalism, 1791-1991 (Canadian Study of Parliament Group, Ottawa, 1992), $17-27$.

Bierstedt, Robert, "Legitimacy" in Julian Gould \& William Kolb (eds.), A Dictionary of the Social Sciences (Tavistock Publications, London, 1964), 386-387.

Blake, Lord Robert, "The Crown and Politics in the Twentieth Century" in Jeremy Murray-Brown (ed.), The Monarchy and its Future (George Allen \& Unwin, London, 1969), 11-26.

Bogdanor, Vernon, "Britain and Europe: The Myth of Sovereignty" in R. Holme \& Michael Elliott (eds.), 1688-1988 Time for a New Constitution (Macmillan, London, 1988), 81-102.

Bogdanor, Vernon, "The United Kingdom” in David Butler \& D.A. Low (eds.), Sovereigns and Surrogates: Constitutional Heads of State in the Commonwealth (Macmillan, London, 1991), 10-40.

Bolger, James, "The American Constitutional Experience and Issues of Sovereignty: Lessons for New Zealand" in Colin James (ed.), Building the Constitution (Victoria University of Wellington Institute of Policy Studies, Wellington, 2000), 48-57.

Booth, Rev'd.Ken, "A Pakeha Perspective on Te Tino Rangatiratanga" in J. Crawford (ed.), Church and State: Te Tino Rangatiratanga (College of St. John the Evangelist, Auckland, 1998) Selwyn Lectures 1996, 1-36.

Brady, Wendy, "Republicanism: An Aboriginal View" in Wayne Hudson \& David Carter (eds.), The Republican Debate (N.S.W. University Press, Sydney, 1993), 145-148.

Brook Cowen, Penelope, "New Liberalism" in Raymond Miller (ed.), New Zealand Politics in Transition (Oxford University Press, Auckland, 1997), 341-349.

Brookfield, F.M., "Parliament, the Treaty, and Freedom - Millennial Hopes and Speculations" in Philip Joseph (ed.), Essays on the Constitution (Brookers, Wellington, 1995), $41-60$. 
Brookfield, F.M., "The Governor-General and the Constitution” in Hyam Gold (ed.), New Zealand Politics in Perspective (3rd edn., Longman Paul, Auckland, 1992), 77-85.

Brookfield, F.M., "The New Zealand Constitution: the Search for Legitimacy" in Sir HughKawharu (ed.), Waitangi: Maori and Pakeha Perspectives of the Treaty of Waitangi ed. Sir Hugh Kawharu (Oxford University Press, Auckland, 1989), 1-24.

Canning, J.P., "Law, sovereignty and corporation theory, 1300-1450" in J.H. Burns (ed.), The Cambridge History of Medicval Political Thought c.350-c.1450 (Cambridge University Press, Cambridge, 1988), 454-476.

Cookeof Thorndon, Lord, "The suggested revolution against the Crown" in Philip Joseph (ed.), Essays on the Constitution (Butterworths, Wellington, 1995), 28-40.

Cox, Noel \& Raymond Miller, "The Monarchy" in Raymond Miller (ed.), New Zealand Government and Politics (Oxford University Press, Melbourne, 2003), 50-62.

Crisp, L.F., "The Unrelenting Penance of Federalist Isaac Isaacs, 1897-1947" in John Hart (ed.), Federation Fathers (University of Melbourne Press, Melbourne, 1991), 186-271.

Crommelin, Richard \& Gareth Evans, "Explorations and Adventures with Commonwealth Powers", in Gareth Evans (ed.), Labor and the Constitution 1972-1975 (Heineman, Richmond, Victoria, 1977), 24-75.

Deane, Roderick, "Globalisation and Constitutional Development" in Colin James (ed.), Building the Constitution (Victoria University of Wellington Institute of Policy Studies, Wellington, 2000), 112-117.

Dixon, Chandra, "Marxism" in Raymond Miller (ed.), New Zealand Politics in Transition (Oxford University Press, Auckland, 1997), 350-358.

Du Plessis, Rosemary, "Women, Feminism and the State" in Brian Roper \& Chris Rudd (eds.), The Political Economy of New Zealand (Oxford University Press, Auckland, 1997), 220-236.

Du Plessis, Rosemary \& Jane Higgins, "Feminism" in Raymond Miller (ed.), New Zealand Politics in Transition (Oxford University Press, Auckland, 1997), 328-340.

Dunbabin, Jean, "Government" in J.H. Burns (ed.), The Cambridge History of Mediaval Political Thought c.350-c.1450 (Cambridge University Press, Cambridge, 1988), 477-519.

Dunn, John, "The concept of trust in the politics of John Locke" in R. Rorty (ed.), Philosophy in History (Cambridge University Press, Cambridge, 1984), 279-302.

Dyzenhaus, David, “The Compulsion of Legality” in Victor V.Ramraj (ed.), Emergencies and the Limits of Legality (Cambridge University Press, Cambridge, 2008), 33-59.

Elias, Dame Sian, "The Treaty of Waitangi and Separation of Powers in New Zealand" in B.D. Gray \& R.B. McClintock (eds.), Courts and Policy: Checking the Balance: papers presented at a conference held by the Legal Research Foundation at the Aotea Centre, Auckland, on 5 and 6 August 1993 (Brookers/Legal Research Foundation, Wellington, 1995), 206-230.

Elliott, Michael, "Constitutionalism, Sovereignty and Politics" in R. Holme \& Michael Elliott (eds.), 1688-1988 Time for a New Constitution (Macmillan, London, 1988), $25-40$.

Evatt, Elizabeth, "The Acquisition of Territory in Australia and New Zealand" in C.H. Alexandrowicz (ed.), Studies in the History of the Law of Nations (Nijhoff, The Hague, 1968) Grotian Society Papers No. 16, pp. 16-45.

Finnis, J., "Revolution and Continuity of Law" in A.W.B. Simpson (ed.), Oxford Essays in Jurisprudence (2nd series, Oxford University Press, Oxford, 1973), 44-76. 
Garnett, George, “Ducal' Succession in early Normandy" in George Garnett \& John Hudson, Law and Government in Medieval England and Normandy (Cambridge University Press, Cambridge, 1994), 80-110.

Goldfinch, Shaun, "The State" in Raymond Miller (ed.), New Zealand Government and Politics (Oxford University Press, Melbourne, 2001), 511-520.

Gowlland-Debbas, Vera, "Collective responses to the unilateral declaration of independence of Southern Rhodesia and Palestine: An application of the legitimizing function of the United Nations" in Ian Brownlie \& D.W. Bowett, The British Year Book of International Law 1990 (Clarendon Press, Oxford, 1991), 135.

Grainger, Gareth, "Australian Constitutional Monarchy and the Future" in Gareth Grainger \& Kerry Jones (eds.), The Australian Constitutional Monarchy (A.C.M. Publishing, Sydney, 1994), 157-180.

Grey, Earl, "Parliamentary Government" in H.J. Hanham, The Nineteenth Century Constitution, 1815-1914 (Cambridge University Press, Cambridge, 1969), 13-16.

Hackhsaw, Frederika, "Nineteenth Century Notion of Aboriginal Title" in Sir HughKawharu (ed.), Waitangi: Maori and Pakeha Perspectives of the Treaty of Waitangi (Oxford University Press, Auckland, 1989), 92-120.

Hadfield, B. "Judicial Review and the Prerogative Power" in Maurice Sunkin \& Sebastian Payne (eds.), The Nature of the Crown: A Legal and Political Analysis (Oxford University Press, Oxford, 1999), 197-232.

Harris, P. \& Elizabeth McLeay, "The Legislature" in G. Hawke (ed.), Changing Politics? The Electoral Referendum 1993 (Victoria University Press, Wellington, 1993), 103-130.

Havel, Vaclav, "The Power of the Powerless" in John Keane (ed.), The Power of the Powerless (Hutchinson, London, 1985), 23-96.

Hayward, Janine, "Commentary" in Alan Simpson (ed.), Constitutional Implications of $M$. M.P. (School of Political Science and International Relations, Victoria University of Wellington, Wellington, 1998), 232-235.

Hayward, Janine, "Who should be Head of State?" in Colin James (ed.), Building the Constitution (Victoria University of Wellington Institute of Policy Studies, Wellington, 2000), 261-266.

Howard, Colin \& Cheryl Saunders, "The Blocking of the Budget and the Dismissal of the Government" in Gareth Evans (ed.), Labor and the Constitution 1972-1975 (Heinemann, Richmond, Victoria, 1977), 277-287.

Hudson, Wayne \& David Carter, "Refining the issues" in Wayne Hudson \& David Carter (eds.), The Republican Debate (N.S.W. University Press, Sydney, 1993), 2-35.

Hurstfield, Joel, "The Succession Struggle in Late Elizabethan England" in S.J. Bindoff et al (eds.), Elizabethan Government and Society (Athlone Press, London, 1961), 369-396.

Jackson, Moana, "Maori Law, Pakeha Law and the Treaty of Waitangi" in Ramari Young (ed.), Mana Tiriti: The Art of Protest and Partnership (Haeata Project Waitangi/City Art Gallery/Daphne Brasell Associates Press, Wellington, 1991), 15-16.

Kantorowicz, Ernst, "Kingship under the impact of scientific jurisprudence" in Marshall Clagett et al (eds.), Twelfth century Europe (University of Wisconsin Press, Madison, 1961), 89-111.

Keith, Sir Kenneth, "International Law and New Zealand Municipal Law" in J.F. Northey (ed.) The A.G. Davis Essays in Law (Butterworths, London, 1965), 130-148.

Kelsey, Jane, "Aotearoa New Zealand: The Anatomy of a State in Crisis" in Andrew Sharp (ed.), Leap into the dark (Auckland University Press, Auckland, 1994), 178-206.

Kelsey, Jane, "Legal Imperialism and the Colonization of Aotearoa" in Paul Spoonley et al (ed.), Tawiwi: Racism and Ethnicity in New Zealand (Dunmore Press, Palmerston North, 1984), 20-43. 
Kelsey, Jane, "Restructuring the Nation: The Decline of the Colonial Nation-State and Competing Nationalisms in Aotearoa/New Zealand" in Peter Fitzpatrick (ed.), Nationalism, Racism and the Rule of Law (Dartmouth, Aldershot, 1995), 177-194.

Kingsbury, Benedict, "The Treaty of Waitangi: some international law aspects" in Sir HughKawharu (ed.), Waitangi: Maori and Pakeha Perspectives of the Treaty of Waitangi (Oxford University Press, Auckland, 1989), 121-157.

Ladley, Andrew, "The Head of State: The Queen and the Governor-General" in Raymond Miller (ed.), New Zealand Politics in Transition (Oxford University Press, Auckland, 1997), 51-61.

Ladley, Andrew, "Who should be Head of State?" in Colin James (ed.), Building the Constitution (Victoria University of Wellington Institute of Policy Studies, Wellington, 2000), 267-275.

Lapsley, Gaillard, "The Parliamentary Title of Henry IV" in Geoffrey Barraclough \& Helen Cam (eds.) Crown Community and Parliament in the Later Middle Ages (Blackwell, Oxford, 1951) reprinted from (1934) 94 English Historical Review 423-449.

Lipset, Seymour Martin, "Social Conflict, Legitimacy, and Democracy" in William Connolly (ed.), Legitimacy and the State (Basil Blackwell, Oxford, 1984), 88-103.

Loughlin, Martin, "The State, the Crown and the Law" in Maurice Sunkin \& Sebastian Payne (eds.), The Nature of the Crown: A Legal and Political Analysis (Oxford University Press, Oxford, 1999), 33-76.

Lower, A.R.M., "The Origins of Democracy in Canada" in Welf Heick (ed.), History and Myth: Arthur Lower and the Making of Canadian Nationalism (University of British Columbia Press, Vancouver, 1975), 26-33.

Macridis, Roy, "Major Characteristics of the Traditional Approach" in Bernard Susser, Approaches to the Study of Politics (Macmillan Publishing, New York, 1992), 16-49.

Maddox, Graham, "The Possible impact of Republicanism on Australian Government" in George Winterton (ed.), We, the People (George Allen \& Unwin Australia, North Sydney, 1994), 125-139.

McGechan, R.O., "Status and Legislative Inability" in J.C. Beaglehole (ed.), New Zealand and the Statute of Westminster (Victoria University College, Wellington, 1944), 65-105.

McHugh, Paul, "A History of the Modern Jurisprudence of Aboriginal Rights - Some Observations on the Journey So Far" in David Dyzenhaus, M. Hunt and Grant Huscroft (eds.), A Simple Common Lawyer: Essays in Honour of Michael Taggart (Hart Publishing, Oxford, 2009).

McHugh, Paul, "Constitutional Theory and Maori Claims" in Sir HughKawharu (ed.), Waitangi: Maori and Pakeha Perspectives of the Treaty of Waitangi (Oxford University Press, Auckland, 1989), 25-63.

McIntyre, David, "Peter Fraser's Commonwealth" in A.D. McIntosh (ed.), New Zealand in World Affairs (Price Milburn/New Zealand Institute of International Affairs, Wellington, 1977), Vol. 1, 1945-1957.

Miller, Raymond \& Noel Cox, "The Monarchy" in Raymond Miller (ed.), New Zealand Government and Politics (Oxford University Press, Melbourne, 2001), 48-60.

Milsom, S.F.C., "Inheritance by women in the Twelfth and Early Thirteenth Centuries" in Arnold Morris (ed.) On the Laws and Customs of England - Essays in Honour of Samual E Thorne (University of North Carolina Press, Chapel Hill, 1981), 60-89.

Moloney, Pat, "Neo-Liberalism: A Pluralist Critique" in Raymond Miller (ed.), New Zealand Government and Politics (Oxford University Press, Melbourne, 2001), 533-543.

Moloney, Pat, "Pluralist Theories of the State" in Raymond Miller (ed.), New Zealand Politics in Transition (Oxford University Press, Auckland, 1997), 317-328. 
Morrow, John, "Neo-Liberalism" in Raymond Miller (ed.), New Zealand Government and Politics (Oxford University Press, Melbourne, 2001), 521-532.

Morton, John, "Aboriginality, Mabo and the Republic: Indigenising Australia" in B. Attwood (ed.), In the Age of Mabo: History, Aborigines and Australia (Allen \& Unwin, St. Leonards, Sydney, 1996), 117-135.

Mulgan, Richard, "A pluralist analysis of the New Zealand State" in Brian Roper \& Chris Rudd (eds.), State and Economy in New Zealand (Oxford University Press, Auckland, 1993), 128-146.

Naufahu, Vahoi, "Australia and the Monarchy - A Pacific Island Migrant View" in Gareth Grainger \& Kerry Jones (eds.), The Australian Constitutional Monarchy (A.C.M. Publishing, Sydney, 1994), 131-136.

Nelson, Janet L., "Inauguration rituals" in P.H. Sawyer \& I.N. Wood (eds.), Early Medieval Kingship (School of History, Leeds, 1977), 50-71.

Nelson, Janet L., "Kings, Kingdoms and Consent" in P.H. Sawyer \& I.N. Wood (eds.), Early Medieval Kingship (School of History, Leeds, 1977), 6-29.

Nelson, Janet L., "Kingship and empire" in J.H. Burns (ed.), The Cambridge History of Medieval Political Thought c.350-c.1450 (Cambridge University Press, Cambridge, 1988), 211-251.

O'Connell, Daniel, "Monarchy or Republic?" in Geoffrey Dutton (ed.), Republican Australia? (Sun Books, Melbourne, 1977), 23-43.

Odgers, J. R., Harry Evans \& Rosemary Laing (eds.), "Chapter 12: Legislation, Section 25: Governor-General's assent” in Odgers' Australian Senate Practice (13th edn., Department of the Senate, Canberra, 2012).

Oliver, Peter, "Cutting the Imperial link - Canada and New Zealand" in Philip Joseph (ed.), Essays on the Constitution (Brookers, Wellington, 1995), 368-404.

Partington, Martin, "The Reform of Public Law in Britain: Theoretical Problems and Practical Considerations" in Patrick McAuslan \& John McEldowney (eds.), Law, Legitimacy and the Constitution: Essays marking the Centenary of Dicey's Law of the Constitution (Sweet \& Maxwell, London, 1985), 191-211.

Payne, Sebastian, “The Royal Prerogative” in Maurice Sunkin \& Sebastian Payne (eds.), The Nature of the Crown: A Legal and Political Analysis (Oxford University Press, Oxford, 1999), 77-111.

Pennington, Kenneth, "Law, Legislative authority and theories of government, 1150-1300" in J.H. Burns (ed.), The Cambridge History of Medieval Political Thought c.350-c.1450 (Cambridge University Press, Cambridge, 1988), 424-453.

Phillips, Jock, "The Constitution and Independent Nationhood" in Colin James (ed.), Building the Constitution (Victoria University of Wellington Institute of Policy Studies, Wellington, 2000), 69-76.

Pullen, W.R., "The Constitution of the Collegiate Church" in Rev'd. EdwardCarpenter, $A$ House of Kings (Baker, London, 1966), 450-464.

Rees, W.J., "The Theory of Sovereignty Restated" in Peter Laslett (ed.), Philosophy, Politics and Society: A Collection (Basil Blackwell, Oxford, 1956), 56-82.

Roper, S. Brian, "Neo-Liberalism: A Radical Critique" in Raymond Miller (ed.), New Zealand Government and Politics (Oxford University Press, Melbourne, 2001), 544-555.

Ross, Angus, "New Zealand Governors-General in the Inter-war Years" in G.A. Wood \& P.S. O'Connor, WP Morrell: A Tribute (University of Otago Press, Dunedin, 1973), 207-221. 
Round, J. Horace, "The Succession to the Crown" in J. Horace Round, Studies in Peerage and Family History (reprinted by Woburn Press, London, 1971, first published 1907), $457-478$.

Rubin, Alfred, "Historical and Legal Background of the Falkland/Malvinas Dispute" in Alberto \& Anthony Arend (eds.), The Falklands War - Lessons for Strategy, Diplomacy and International Law (Allen \& Unwin, Boston, 1985), 9-21.

Sanders, Douglas, "The Indian Lobby" in Keith Banting \& Richard Simeon (eds.), And No One Cheered: Federalism, Democracy and the Constitution Act (Methuen, Toronto, 1983), 301-332.

Saunders, Cheryl, "The Australian Experience: Lessons, Pointers and Pitfalls" in Colin James (ed.), Building the Constitution (Victoria University of Wellington Institute of Policy Studies, Wellington, 2000), 276-286.

Schaar, John H., "Legitimacy in the Modern State" in William Connolly (ed.), Legitimacy and the State (Basil Blackwell, Oxford, 1984), 104-133.

Sellar, W.D.H., "The Common Law of Scotland and the Common Law of England" in R.R. Davies (ed.), The British Isles 1100-1500: Comparisons, Contrasts and Connections (J. Donald Publishers, Edinburgh, 1988), 82-99.

Sharp, Andrew, "Constitution" in Raymond Miller (ed.), New Zealand Government and Politics (Oxford University Press, Melbourne, 2001), 37-47.

Skinner, Quentin, "Conquest and Consent: Thomas Hobbes and the Engagement Controversy" in G.E. Aylmer (ed.), The Interregnum - The Quest for Settlement, 1640-1660 (Archon Books, Hamden, 1972), 79-98.

Skocpol, Theda, "Bringing the State Back In: Strategies of Analysis in Current Research" in Bernard Susser, Approaches to the Study of Politics (Macmillan Publishing, New York, 1992), 457-497.

Smith, Sir David, "The Australian Constitution and the Monarchy/Republic Debate" in Gareth Grainger \& Kerry Jones (eds.), The Australian Constitutional Monarchy (A.C.M. Publishing, Sydney, 1994), 69-86.

Smith, Sir Thomas, "Pretensions of English Law as "Imperial Law" in The Laws of Scotland (Law Society of Scotland/Butterworths, Edinburgh, 1987), Vol. 5, paras. 711-719.

Stockley, Andrew, "Becoming a Republic? - Issues of Law" in Luke Trainor (ed.), Republicanism in New Zealand (Dunmore Press, Palmerston North, 1996), 81-112.

Stockley, Andrew, "Becoming a Republic? - Matters of Symbolism” in Luke Trainor (ed.), Republicanism in New Zealand (Dunmore Press, Palmerston North, 1996), 61-80.

Strickland, Matthew, "Against the Lord's anointed: aspects of warfare and baronial rebellion in England and Normandy 1075-1265" in George Garnett \& John Hudson, Law and Government in Medieval England and Normandy (Cambridge University Press, Cambridge, 1994), 56-79.

Sturdy, D., "Continuity versus change: Historians and English coronation in the Medieval and Early Modern Periods" in Jãnos Bak (ed.), Coronation: Medieval and Early Modern Monarchic Ritual (Center for Medieval and Renaissance Studies, University of California/University of California Press, Los Angeles, 1990), 228-245.

Thomas, Philip, "The Coburg Succession and the British Crown" in Burke's Peerage baronetage and knightage (Burke's Peerage, London, 1967), 31-35.

Thomas, Philip, “The Princes of Great Britain” in Burke's Peerage baronetage and knightage (Burke's Peerage, London, 1963), xxvii-xxx.

Thompson, Elaine, "Giving ourselves better Government" in Donald Horne et al, The Coming Republic (Pan Macmillan, Sydney, 1992), 148-169. 
Wade, Sir William, "The Crown, Ministers and Officials: Legal Status and Liability", in Maurice Sunkin \& Sebastian Payne (eds.), The Nature of the Crown: A Legal and Political Analysis (Oxford University Press, Oxford, 1999), 23-32.

Walpole, Horace, "Historic Doubts on the Life and Reign of Richard III" in Paul Kendall (ed.), Richard III: The Great Debate (W.W. Norton, New York, 1965), 159-239.

Whitlam, E. Gough, "The Labor Government and the Constitution", in Gareth Evans (ed.), Labor and the Constitution 1972-1975 (Heineman, Richmond, Victoria, 1977), 305-330.

Williams, Rev'd. David, “Te Tiriti o Waitangi” in A. Blank et al (eds.), He Korero Mo Waitangi 1984 (Te Runanga o Waitangi, Auckland/Wellington, 1985), 159-171.

Winterton, George, "A New Zealand Republic" in Alan Simpson (ed.), Constitutional Implications of M.M.P. (School of Political Science and International Relations, Victoria University of Wellington, Wellington, 1998), 204-231.

Winterton, George, "The Constitutional Position of Australian State Governors" in H.P. Lee \& George Winterton (eds.), Australian Constitutional Perspectives (The Law Book Co., Sydney, 1992), 274-335.

Wood, Antony, "New Zealand" in David Butler \& D.A. Low (eds.), Sovereigns and Surrogates: Constitutional Heads of State in the Commonwealth (Macmillan, London, 1991), 109-143. 